\title{
Annotated Bibliography of Human Factors Applications Literature
}

\author{
Prepared for \\ U.S. Department of Energy \\ Office of Nuclear Safety \\ by \\ Lawrence Livermore National Laboratory \\ Livermore, California 94550 \\ and \\ Essex Corporation \\ Alexandria, Virginia 22314
}

September 30, 1984

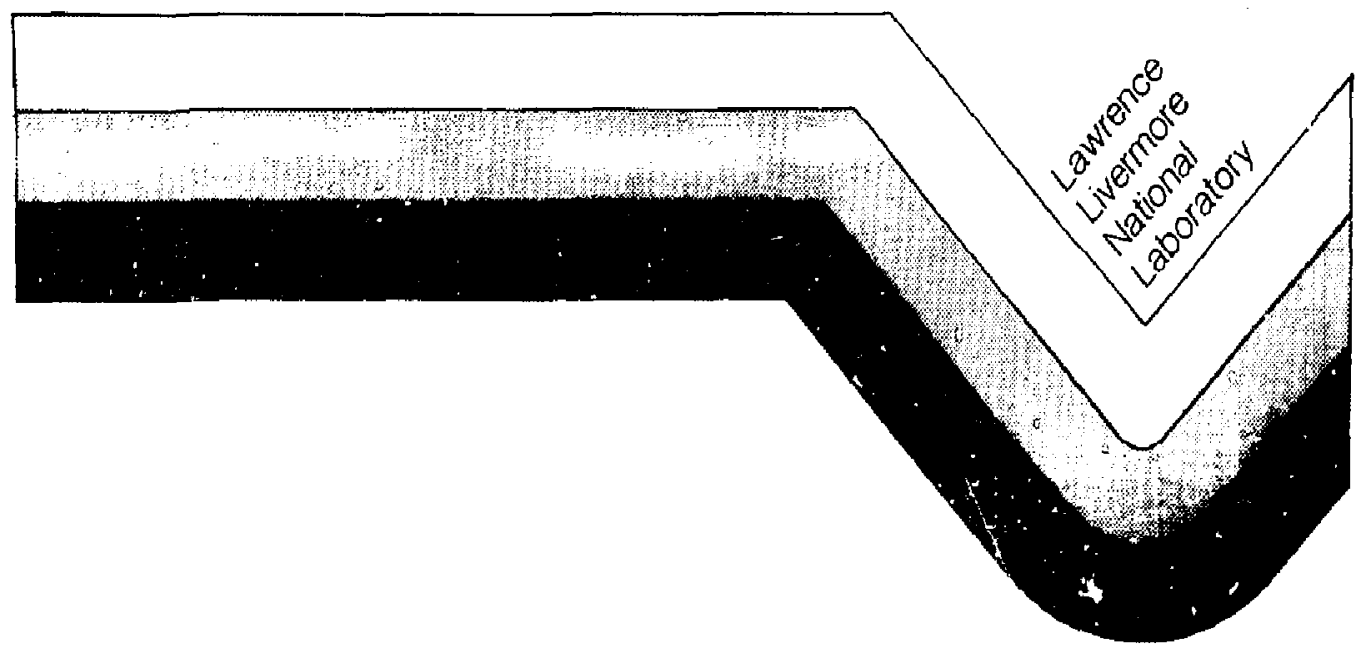




\section{DISCLAIMER}

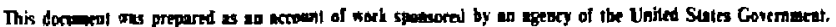

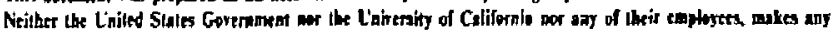

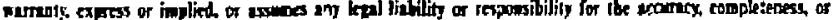

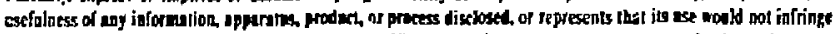

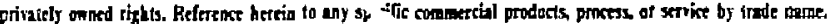

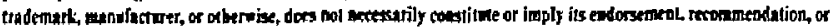

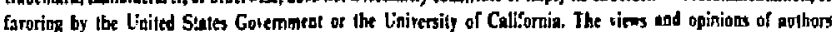

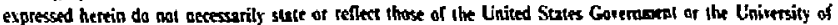
Califormia, and shall not be used for advertisisg or product endorsement purposes. 


\section{ANNDTATED BIBL IOCRAPHY OF \\ HUMANFACTORS APPLICATIONS LITERATURE}

Prepared for

U.S. Department of Energy

Office of Nuclear Safety

b)

Lawrence Livermore National Laboratory

Livermore, California 94550

and

Essex Corporation

Alexandria, Virginia 22314

September 30, 1984 


\section{CONTENTS}

SECTION 1.0

INTRODUCIION

1.1 Backgraund

1.2 Organization

SECTION 2.0

AINOTATED BIELIOGRAPHY

SECTION 3.0

SUPPLEMENTIAL BIBLIOGRAPHY

APPENDIX 1

INOEX OF ANNOTATED BIELIOGRAFHY BY TOPIC AREA 


\title{
ACKNOWLEDEMENTS
}

The principal investigator and task manager for development of this bibliography was Denise B. McCafferty of Essex Corporation. Overall technical direction was provided by L. Rolf Peterson of Lawrence Livermore National Laboratory and Barbara Paramore of Essex. Charles C. Campbell was the technical monitor for the Office of Nuclear Safety, U.S. Department of Energy.

Major contributions were made in the development and preparation of the bibliography by the following Essex personnel:

\author{
Literature Search and Annotation \\ Phil Durham \\ Mike Francher \\ Cindy Gal \\ Lois Grealis \\ Jennifer Payette \\ Editing \\ Jim Cammisa \\ Production \\ Vanesse Weedon \\ Karen Miller
}


SECTION 1,0

INTRODUCTION 


\subsection{MTRODUCTION}

\subsection{Beckground}

This bibliography was prepared as part of the Human Factors Technology Project, FY 1984, sponsored by the Office of Nuclear Safety, U.S. Department of Energy. The project was conducted by Lawrence Livermase National Laboratory, with Essex Corporation as a subcontractor.

The material presented here is a revision and expension of the bibliographic material developed in FY 1982 as part of a previous Human Factors Technology Project. The previous bibliography was published September 30, 1982, as Attachment 1 to the FY 1982 Project Status Report.

\subsection{Orgarization}

The remaining sections of this volume contain the bibliography and an indax. Section 2.0 presents the annotated bibliography; references are given in alphabetical order on individual pages, followed by an abstract and suggested applications. The upper righthand corner of each page lists app.icahle topic areas for the references. Section 3.0 is a supplemental bibliography, listing in alphabetical order thuse references for which no abstracts were available. Appendix 1 indexes the annotated bibliography by topic area, listing ali references applicable to each topic. 
SECTION 2.0

ANNOTATED BIBLIOGRAPHY 
Acoustical Society of America. (1971). Associsted terminolagy (including mechanical shock and yibration) (ANSI 91.1-1971 R1960). New York: Author.

\section{ABSTRACT}

This standard establishes acoustical tetminoicgy including mechanical shock and vibration. Terminology is outlined in aiphabetical order within the following categories: acoustics, vibration frequency, harmonics, velocity, ievels, and criterio for sensory and auditory thresholds.

\section{APPLICATION}

This report was intended for use by industrial psychologists, induatrial humen factors personnel, and various vendors involved with acoustical considerations in design systems. This may prove useful to personnel performing noise surveys in control room desir reviews. 
Advisory Committee on Reactor Safeguards. (1980). An apprnach io quantitative safety goals for nuclear power plants (NUREG_-1739). Washington, DC: Nuclear Regulatory Commission.

\section{ABSTRACT}

A possible approach to quantitative safety goals for nuclear power plants is provided by the Advisory Committee on Reactor Safeguards. The report contains three parts: 1. A review of several proposals for quantitative risk criteria. 2. A preliminary proposal for a possible approach to quentitative safety goels. 3. A brief evaluation of several technologies, including nucleas, in terms of the proposed criteria. The trial epprosch to quantitative safety criteria is divided into two major tasks: The firat is the predominantly social and political problem of setting the safety criteria, which are termed decision rules; the second is the technical question of esilmating the risks and deciding whether the safety criteria have been met.

The proposed numerical values for use in decision rules are intendnd to stimuiate further discussion and evaluation leading to the future oizvelopment of, suitable risk ecceptance levels.

\section{APPLICATION}

Since safety is of great imporiance in the nuclear field, this naper offers a quantitative epproach to those interested in nuclear safety. 
3ob Performance Aidh :

HFE(General)

American Naticnal Standards Institure. (1971). Method for the physical measurament of sound (ANiSI 91.2-1962). New " Sork: Author.

\section{ABSTFACT}

This report provides informision as to different methods and types of sound detection. Measurements are made in scund pressure levels, decibels, and ambient sound pressure level correction. Determinations are made to standerdizo deta cullection methods through calibrated microphones, sound frequency analyses, and directivity. Summarily, results indicate that iow-frequency sounds need absorption ii sider to reduce reverberalion.

\section{APPLICATION}

This report provides information which is intended for sound measuie:nent in humari factors engineering as well as job performance anaiygis. This maturial may be useful for nolise surveys for coritrol:oom cesign reviews 
American Natlonal Stendards Institute. (1972). American national standard edministrative controls and quality assurance for the operational phase of nuclear power plants revision of N18.7-1972 (ANSI 18.7-1976). L8Grange Park, IL: Author.

\begin{abstract}
Historically, quality assurance as an accepted discipline has been associated with menufacturing and construction activities from which it originated as a separate function.

$i$ i contrast to potential effects of deficiencies in manufacturing and construction, deficiencies in operating activities can be much more immediate in their effect. For example, it is important that the dynamic aspects of operation be monitored on an essentiaily continuous basis. Instrumentation for monitoring, control, and actuation of safely systems, and observations by and response from the operating ataff, are both extensively used for this purjose in nuelear power plants. In a nuclear power plant employing proper administrative controls and quality assurence practices, the critical eppraisal by supervisory personnel of plant operating evolutione, trends in perameters, maintenance, and day-to-day work practices is the most significant portion of absuring the quality of plant operation (in the broad sense of the term "quality sssurance"), whereas quality assurance (as a technical discipline or en organizational cuit) of operating activities is associated principally with checking the adequacy and completeness of work after it is completed. This revision emphasizes that both operating staff and personnel performing other quality assurance functions have important roles in the "... planned and systematic activities. .." specified in the Appendix B definition of quality.
\end{abstract}

\title{
APHICATION
}

This ANSI standard discusses administrative controls and quaiity assurance for operations and maintenance. This report is especislly useful for persoris involved with generation, production, or contro: of procedures and documentation. 
Americen National Stendards lnstitute. (1980). IEEE trial-use standard criteria for the design of the control room complex for a nuclear power generating etation (ANSI/IEEE Sid 567). New York: Author.

\section{ABSTRACT}

This stendard addresses the central control room of a nuclear power generating station and the overall complex in which this room is housed. The puspose of this standard is to provide guidance for the design of the nuclear power plant control room complex, which must meet applicable criteria in Appendix A of 10 CFR 50. Requirements are established and recommendations are offered to aid the designer in meeting the applicable general design criteria.

\section{AFPLICATION}

This stendard provides guidance for the design of nuclear power plant contral rooms which meeis the criteria in Appendix A, 10 CFR 50. 
Atmerican Nuclear Society. (1978). American national standard for selectian and training of nuclear power plant personnel (ANSI/AN5 3.1-1978). LaGrenge Park, ll.: Author.

\section{ABSTRACT}

This report provides criteria for the selection and training of personnel for stationary nuclear power plants. It addresses itgelf to the qualificetion, responsibilities, and training of persennel in operating and support organizations necessary to efficiently operate a nuclear power plant.

\section{APPUCATION}

This report is intended to provide support for training personnel, supervisors, and licensing personnei. 
American Nuclear Society. (1979). American national standard guidelines for considering user needs in computer program development (ANSI/AN5 10.5-1979). LaGrange Park, IL: Author.

\section{ABSTRACT}

This report provides guidelines for accommodating user needs in prepering computer programs for scientific and engineering applications. These guidelines were developed to ensure proper application and to simplify using the computer program.

\section{APPLICATION}

This report is intended for use by data processing personnel and computer programmers for application in their own programs. 
American Nuclear Society. (1979). Immediate evacuation signal for use in industrial installations (ANSI/ANS N2.3-1979). New York: Author.

\section{ABSTRACT}

This standard defines the characteristics of signals for situations requiring prompt evacuation of personnel to prevent serious injury. Devices required to activate the signal are discussed although not specifjed. The reliability requirements of the signal-generating system are specified. Operational testing requirements are specified fo: the signalgenerating system.

\section{APPUICATION}

This standard wes developed for use in installations where ionizing radiation exposures might occur, out it may be used for other establishments where immediate evacuation is required. 
American Nuclear Sociaty. (1983). Criteria for rennte shutdown for light water reactors (ANSI/ANS 58,6-1983). LaGrange Park, IL: Aithor.

\section{ABSTRACT}

This report provides design criteris for specific controls and manitoring ezuipment which are utilized during a safe shutdown condition. Control locations are plised in areas that are physically remote from the control room. These control locations are utilized only when control room access is rot possible or desirable. Verious standards are applied in the design, cable spreading, and auxiliary locations of controls and transfer devices.

\section{APPLICATION}

This report is utilized in remote shutdown criteria development in either normal operating modes or emergency procedures. 
Analyois and Technolcgy. (1983). Guidelines for job and task analygis for DOE nuclear facilities (Repent No. DOE/EP-0095). Waghington, DC: Department of Energy.

\section{ABSTRACT}

The guidelines are intended to be responsive to the need for information on methodology, procedures, content, and use of job and tagk analysie since the establishment of a requirement for position takk analysis for Category $A$ reactors in DOE 5480.1A, Chepter VI. The guide describes the general approach and methods currently being utilized in the nuclear industry and by several DOE contractors for the conduct of job and task aralysis and applications to the development of training pragrams or evaluation of existing prograns. In addition, other applications for job and task analygis are described, including: operating procedures development, personnel management, system design, communications, and human performance predictions.

\section{APPLICATION}

This guide outlines the job and task analysis process necessary for position task analysis projects for DOE Category A reactors. This information could also ve helpful for similar projects in other DOE facilities. 
Anderson, J.L. '1981). Operational aids for reactor nperators. Interim repnnt; ORNL foreign trip report (ORNL/FTR-1032). Washington, DC: Nuclear Regulatory Commission.

\begin{abstract}
This trip report covers participation in two workshops at the Halden Reactor Project, Sarpsborg, Norway, and a visit to operating reactors in the Linited Kingdom. Of particular note are the following:

1. The intent of the Halden Reactor Project to procure a new simulator for operator performance experiments.

2. The development of functional and design requirements for a stand-alone system to simplify the presentation of alarm information.

3. The relative aggressiveness with which the UK has implemented computer technology in their reactors and the apparent wealth of operating experience this has generated.
\end{abstract}

\title{
APPLICATION
}

This Lrip was generated by an NRC.sponsored research program, "Operational Aids for Reactor Operators." The program's oj jective is to provide a technical basis for developing design requirements, developing reguletory review criteria, and assessing the impact on sáfety for mathods to enhance the capabilities of reactor operators. 
Bagehi, C.N., \& Gottilla, S.C. (1981, February). Application of human engineering criteria to ennunciator display systems in a large fossil pover station. Proceedings of the IEEE Power Engineering Society Winter Meeting, Atlanta, GA.

\section{ABSTRACT}

This paper present: a conceptual design of a human engineered alarm system for a large fossil-fueled power generating station. Well-known human factors engineering principles have been incorporated into the design. Main features of this design are integration of hard-wired annunciators, localized alarms, and CRT alarms into a comprehensive syitiem.

\section{APPLICATION}

The primary objective is that the alarm interface between tine operntor and the plant during a multifaceted emergency should become manageable and useful to the cperator. 
Baker, J.T. (1980, February). Automated preventive maintenance program for service industries and public institutions. Industrial Enqineering, 18-21.

\section{ABSTRACT}

The maintenance of a company's physical plant has always been extremely important. This article outlines the important aspects of a facility maintenance program, as well as an automated program. Also outlined are ways to implement the program.

\section{APPUCATION}

This program for a n:ulti-facility operation can be adapted for other applications. 
Benks, W, W. (1980). 5ome suggestions for humen engineering design quidelines relating to CRT displays and software development (Report No. SD-D-80-002). Idaho Falls, ID: ECd G Idaho, Inc.

\section{ABSTRACT}

The present set of guidelines was developed using several techniques including analysis of existing literature, review of recent studies, and spplication of standard human engineering principles. Interface guidelines relating to CRT displays and softwere development are developed for the following areasi display formats, frame content, command language, recovery procedures, user entry techniques, and response time considerations. The chief characteristic of these guidelines is specificity, reflecting specific issues rather than general considerations. In addition, wherever possible, stress is placed on quantitative rather than qualitative considerations. At the time of publication, these guidelines viere not complete or final.

\section{APPLICATION}

This report contains a series of specific guidelines which, it is hoped, will aid in the designn of visual interfaces and contribute to more effective man-computer interactions. 


\section{CRTs, VOTs, SPOS}

Banks, W.W. (1981). Human enqineering CRT display development quidelines (Report No. SD-B-8I-002). Idaho Falls, ID: EG\&G Idaho, Ir.c., System Safety Division.

\section{ABSTRACT}

This internal company report contains epecific and general ģuidelines for designing electronic visual displays (CRT8) to enhance the interface between man and machines. These guidelines cover the following areas: general considerstions, display formats, frame content, color, command language, recovery procedures, user entry techniques, response time considerations, and unobtrusive assessment. The report focuses on quantitative rather than qualitative considerations of CRT display guidelines.

\section{APPLICATION}

Since CRT disploys are the dominant medium: for users of interactive computing and control systems, guidelines are needed to design effective interface devices. The report covers aspects of CRT man-machine interface design including displays, procedures, and software. 
Benks, W.W. \& Boone, M.P. (1981). A method for quantifying control ecces ibility. Human Factors, 23, 299-303.

\section{ABSTRACT}

A method of statistically quantifyirg the accessibilit.' of controls is proposed and validated. The resulting index of accessibility $\left(\mathrm{I}_{a}\right)$ takes into account three sources of varialility: operators's -rh envelope, frequency of use, and relative physicai position of contro!s with respect to the operator. Operator ratings and measurement (percent) of controls reached were highly correlated with $\mathrm{I}_{\mathrm{a}}$ values, lending support to the notion that $I_{a}$ is sensitive to very small changes in control placemert.

\section{APPLICATION}

The purpose of the present study is to test the feasibility of a method for quantifying selected human factors design criteria which originally elicited a subjective or qualitative judgment. The objective is to provide a technical basio for developing design requirements and regulatory review criteria, and for assessing the impact on safety for methods to enhance the capabilities of reactor operators. 


\begin{abstract}
Banks, W.W. \& Boone, M.P. (1901). Nuciear contre' room an:unciators: Problems and recommendations (NUREG/CR-2147). Washingtos DC: Nuclaar fegulatory Commission.
\end{abstract}

\begin{abstract}
This report provides an extensive analysis of two test power reactors and two commercial pressurized water reactors. Serious prublems were uncovered with the control room annunciators. In "erviews were conducted with operators, shift supervisors, managers, and maintenance workers. As a result of the interviews and inspections, specific problems were identified. Recommendations were made for improvement in system engineering standerdization.
\end{abstract}

\title{
APPLICATION
}

This report is intended for application in the systems design, emergency planning, and human factors engineering aspects of nuclear inn :rol rooms. 
Banks, W.W. \& Clark, M.T. (1981). Some human engineering color considerations using CRT displays: A review of the literature (Report No. SD-B-81-001). Idaho Falls, ID: EGdG Idaho, Inc.

\section{ABSTRACT}

The purpose of this study is to provide an in-house docurivent to answer many user and programmer questions related io color-generated CRT displaye. The scope of the work is limited to the following areas: (1) accuracy in subject identification; (2) color enhancement for redundancy attributes; and (3) speed of information scquisition. The major emphasis is placed on empirical data collected from end-user test a jecta.

\section{APPLICATION}

This study provides answers to questions which, it is hoped, will aid computer users and programmers in more effective use of color-generated CRT displays. 
CRTs, VDTs, SPDS

Banks, W.W., Gertman, D.L. \& Petersen, R.J (1982). Humen engineering design considerations for cathode ray tubergenerated diaplays (NUREG/CR-2496). Washington, DC: Nuclear Regulatory Commission.

\section{ABSTRACT}

This report ideritifies relevant issues related to humen performance ... confunction with the use of cathode ray tube-generated displays. Twelve primary source documents were identified for human engineering content seview. From these documents a set of 22 variables was selected and analyzed. Each variable is discussed in terms of its impact, relevance, and validity with regard to various standards that have evolved over the past 20 years. Studies related to each standard were also identified and cited that either support or weaken a particular standard. The conclusions drawn in this report indicate that there are areas needing further investigation before valid standards can be generated. Hov'ever, there are many current standsrds that have emple research support to justify them as candidate standards for use by the Nuclear Regulatory Commission. Suitability of these varicus standards is discussed.

\section{APPLICATION}

The preliminary findings in this report suggest that human factors engineering researci is needed in the following areas of CRT-generated displays: image distortion, display formats, work surface light reflection, cognitive fidelity, response time, and phosphor types. 
CRTA, VDTE, SFDS

Banks, W.W., Meyer, O.\&. Clark, Mt (1980, August). Human factors considerations in the design of nuclear process displays. Paper presented at the Engineering Technology Conference, San Francisco, CA.

\section{ABSTRACT}

Process graphic CRT displays in the nuclear industry are the current focus of engineers and scientists involved in advanced' display/control : "elopment. These types of graphic presentations must be cepable of presenting a wide range of information to meet a diversity of human information requirements. These new displays often present a number of new design problems for both engineers and human factors scientists, while at the same time they provide solutions to other problems. For example, advanced control displays must project a highly flexible system of overlapping schematic information end yet simultaneously minimize the effect of too much information, clutter, noise, and visual symbol inter ference which impedes a clear, concise transfer at the man-displey interface.

\section{APPLICATION}

It is the interit of this paper to orgenize and present cognizant literature and issues related to hurnan factors and process control CRT displays. 
Banks, W.W. \& Sprague, R.L (1982). The physiological and pgychological effects of high presuure sodium lighting on graphics arts personnel: A critical review. Idaho Falls, D: EG\&G Idaho, lnc.

\section{ABSTRACT}

An hintengive literature review was initiated to determine whether or not sound evidence exists to support the hypothesis that High Pressure Sodium Vapor Lighting (HPS) may be causatively related to degraded visual performance of graphics arts workers. The literature review yielded rather strong and consistent results indicating that the narrow bandwidth light produced by HPS significantly degrades certain human oculomotor functionis, distorts color perception across the color spectrum (especially in the extreme ranges, such as blue and red), and is highly carrelated with psychological reports of blurring, eye fatigue, dizziness, and headaches. Also, measurements taken in the graphics arts work area produced a calculated color sendition index range of 25 to 67 , well below the minimum acceptable standard of 90 as published in the American National Standards for color rendition suggested for graphics arts workera.

Economic aspects of lighting were found to be major concern in the literature because of the high ratio (approximately 1:250) between lighting cost and productivity costs. Given this ratio, it appears that a one-half of one percent increase in production would be more than enough to justify the doubling of lighting expenditures. The raport recommends a number of approaches to enhancing the performance and productivity of graphics arts employees through changes to the existing lighting environment.

\section{APPLICATION}

Although the specific focus here is on lighting in the context of graphics production, the findings are applicable to any environment (such as a control room) where reading of displays and indicators takes place under artificial lighting. 
Barks, D.B., Kozinsky, EJ. \& Eckel, 5. (1982). Nuclear fower plant control toom task analysis: Pilot study for pressurized water reactors (NUREG/CR-2598). Washington, DC: Nuclear Regulatory Commission.

\section{ABSTRACT}

The purposes of this riclear plant task analysis pilot study were:

1. To demonstrate the use of task analysis techniques on selected abnormal or emergency operation events in a nuclear power plant

2. To evaluate the use of simulator data obtained from an automated Performance Measurement System (PMS) to supplement and validate data obtained by iraditional task analysis methodz

3. To demonstrate sample applicetions of task analysis data to address questions pertinent to nuclear power plant operational sefety: control raom layout, staffing and training requiremente, operating procedures, interpersonal communications, and job performence aids.

Five data sources were investigated to provide information for a task analysis. These sources were (1) written operating procedures (event-based); (2) interviews with subject matter experts (the control room operators); (3) videotapes of the control room operators (senior reactor operators and reactor operators) while responding to each event in a simulator; (4) walk-/talk-throughs conducted by control room operators for each event; and (5) simulator data from the PMS.

A Westinghouse pressurized water reactor nuclear power plant simulator was utilized in this study. A simulator gives researchers the ability to observe actual control manipulations during accident scenarios. Four abnormal or emergency events were studied: nuclear instrument failure; small break loos of coolent accident (LOCA); steam generator tube leak; and inadvertent safety injection at power. Upon completion of the task enalyses, computerized data reduction was perfurrned. A PRIME I-1000 computer was used to manage the task analytic data base.

\section{APPLICATION}

This task analysis will be of interest to those warking in the areas of control room design, procedures, job performance, and simulators in conjunction with training. 
Bartter, W.D., Siegel, AL \& Foderman, P.J. (1982). Job analyels uf the maintenence supervisor and instrument and control supervisor positions for the nuclear power plant maintenance personnel reliability model (NUREG/CR-2668). Wastington, DC: Nuclear Regulatory Commission.

\begin{abstract}
This report attempts to define and elaborate the acto of maintenance technicians in nuclear power plents. The methods, procedures, and results of an analysis of the job of supervisors of maintenance mechanics and of instrument and control technicians in such plante are presented. The results of auch analyses have direct implications relative to the orgenization and cantent of a nuclear plant maintenance reliebility madel.
\end{abstract}

\title{
APPLICATION
}

This study is applicable in the area of task analysis in relation to performence, time, safety, training, and various other abilities for task performance. 
Bauman, M.B., Davideon, M.K. \& Van Cott, H.P. (1984, Dctober). Enhancing plant effectivelıess by impraving organizational communication. Proceedings of the Human Factors Society - 28th Arnual Meeting, San Antonio, TX.

\section{ABSTRACT}

The purpose of this EPRI-sponsored study is to investigate the impact of communication problems on nuclear power plant (NPP) operations and to design, implement, and evaluate alternative programs that address nuclear power plant communication issues, Preliminary survey results from four nuclear power plants showed that six communication areas warranted special attention. These were: timeliness, redundancy, withholding of information, feedback, information amount, and quality of work-related documentation. Two approaches that have been developed to address plant-specific problem areas are presented. One approach irvolves evaluating the ef fectiveness of automated work request systems at two plants as mechanisms for improving interdepartmental communications and job performance. Another focuses on determining the effectiveness of interdepartmental meetings for improving organizational communication. The methods for longitudinally evaluating the effects on organizational cornmunication and plant effectiveness are also presented.

\section{APPLICATION}

This report presents an approach for assessing departmental interfaces and plant communication in the work request process. Methods for enhancing plant effectiveness through improved communication and coordination of work are discussed. 
Bauman, M.B., Pein, R.F., Van Cott, H.P. \& Davidson, M.K. (1983). Survey and analygis of work structure in nuclear power plants (Repart No. EPRI NP-3141). Palo Alto, CA: Electric Power Research lrastitute.

\begin{abstract}
Work structure factors are those that relate to the way in which work at all levels in a plant is organized, staffed, managed, rewarded, and perceived by plant personnel. Research over many years has demonstrated that these work structure factors are closely correlated with organizational effectiveness, safety, and profitability. The work structure of ten nuclear power plants was assessed using questionnaires. Structured "critical incident" interviews were conducted to verify the questionnaire results. The study revfaled that a variety of work structure fector problems do exist in nuclear power plants. The study recommends a prioritized set of candidate research issue; to be considered as part of EPRI's Work Structure and Performance Research Program.
\end{abstract}

\title{
APPUCATION
}

This study demonstrates the importance of work structure in effective nuclear power plant operations. The findings may provide insights to nuclear power plant personnel regarding sources of existing problems and methods for improving organizational effectiveness. 
Basman, M.B., Pain, R.F., l'an Cott, H.P. \& Davidson, M.K. (1983). Work structure in nuclear power plants. Proceedings of the Human Factors Society - 27 th Annual Meeting, 1, 571-575.

\section{ABSTRACT}

This paper describes the assessment of the work structure of ten nuclear power plants. Questionnaires were given to a cross-section of personnel, and structured "critical incident" interviews were conducted to verify the yuestionnaire results. The atudy revealed that a variety of work structure factor problem areas do exist in nuclear power plents.

\section{APPLICATION}

This report provides information useful to all plants in identifying priority problem areas within the work structure. 
Beare, A.N., Crowe, D.S., Kozinsky, E.J., Barks, D.B. \& Haas, P.M. (1982). Criterin for safety-related nuclear power plant operator actions: Initial boiling water reactor (BWR) simulator exercises (NUREG/CR-2534), Washington, DC: Nuclear Regulatory Commission.

\begin{abstract}
The primary objective of the Safety-Related Operator Action Program at Oak Ridge National Leboratory is to provide a data base to support development of criteria for safety-related action by nuclear power plant operators. This report presents initial data obtained fiom ten exercises conducted in a boiling water reactor power plant control room simulator. The ten exercises were performed by 24 groups of operators from three utilities. Operator performance was recorded automatically by a program called the Performance Measuremeit System sun on the simulator's computer. Data tapes were subsequently analyzed to extrast operator response time (RT) and error rate information. In addition, demographic and subjective data were collected and analyzed in an attempt to identify and evaluate the possible effects of selected performance-shaping factors on operator nerformance. Operator RTs to the simulated events generally occurred within the intervals allowed in the draft ANSI-N660 design standard; however, they did not appear to be systernatically related to the severity of the event, which was the basis for ellocation of time margins in the standard. More collective experience in power plant operations was weakly correlated with faster responses. Limited data on omission errors yielded an error rate of greeter then five percent.

The data collected will be compared to field data being collected on similar malfunctions. That comparison will provide a basis for extrapolation of simulator data to actual operating conditjons. A base of operator perforinance data developed from simulator experiments can then be used to establish criteria and standards, evaluate the effects of performance-shaping factors, and support safety/risk assessmerit analyses.
\end{abstract}

\title{
APPLICATION
}

This may be of iriterest to those writing their own data bases or simulating nuclear power plant opersicions. 
Beare, A.N., Dorris, R.E., Bovell, C.R., Crowe, D.S. \& Kozinsky, E.J. (19g3). A simulatarbased study of human ercors in nuclear power plant control room task? (NUREG/CR3309). Washington, DC: Nuclear Regulatory Commission.

\section{ABSTRACT}

The purposes of this study were to empirically establish error rates for control selection and operation during the performance of proceduralized takks in nuclear power plant control rooms during simulated casualties, and to campare the observerd error rates with the human error probabilities in the Hancbook of Human Reliability Analysis with Emphasis on Nuclear Power Plant Applications, NUREG/CR-1278.

\section{APPLICATION}

This report provides a review of human factors analysis in the following areast performance models, risk assessment, error probabilities, and reliability onalysis within date collection procedures. 
Beare, A.N., Dorris, R.E. \& Kozinsky, E.J. (19e2). Response times of nuclear power plant operations: Comparison of field and simulator data. Proceedings of the Human Factors Society - 26th Annual Meeting, 669-673.

\begin{abstract}
This report presents preliminary comparisons of field and simulator performance data for nuclear pawer plant operators. The performance measure used was the time for operators to initiate the first correct manual action in response to an ebnormal or emergency event. Response times (RTs) for experienced operators in the simulator were generally shorter and less variable than in the field data. Two classes of events were distinguished: step events which occur suddenly and ramp events which develop more slowly. For all events, the range of RTs was very lasge, with the 95th percentile RT averaging 5 times the 50th percentile RT. Both the 50th percentile RT and the range were much larger for ramp than for step events in the field, but not in the simulator. To date, simulator events have not modeled the wide variety of circumstances in which field events are embedded, and which are thought to be responsible for the extreme variability of RTs for field events.
\end{abstract}

\title{
APPLICATION
}

This paper presents actual data on performence differences on simulators and in the field. This information may prove useful to training specialists. 
Bell, B.J. \& Swain, A.D. (1983). A procedure for conducting a human reliability analysis for nuclear oswer plants (NUREG/CF-2254), Washington, DC; Nuclear Regulstory Commission.

\section{ABSTRACT}

This document describes in detail a pracedure to be followed in condueting a human reliability analysis as part of a probabilistic ribk assessment when such an analysis is performed according to methods deseribed in NUREG/CR-1278, "Handbook of Human Reliability Analysis with Emphasis or. Nuclear Pawer Plant. Applications." An overview of the procedure describing the major elements of a human reliatility analysis is presented along with detailed descriptions of each element and an example of an actual analysis, An appendix consists of some sample human reliability analysis problems for further study.

\section{APPLICATICN}

This document wouid be useful for persons interested in or conducting human reliability analysis as part of a probabilistic risk assessment. 
HFE (Cenoral)

Bennett, C.A (1977). Spaces for peaple: Human factars in deälgn. Engluwoud Cliffo, NJ: Prentice-f bll

\section{ABSTRACT}

It is assumed that formal interior design coursework and experience teach design. Rather, this book is meant to present what may be additional knowledge on accommodating people while designing. Topics include design of individual, shall or large speces; luminous, sound, and thermal environments; and how to "put it all toyether." Certain auxiliary nondesign topies of importence to the designer are also lncluded.

\section{APPLICATION}

This book is intended for any desigres of interior spares, whether the practicing professional or the student of interior design or architecture. 
Blackman, H.5., Gurtman, D.i., Gilmore, W.E \& Ford, R.E. (1983). Noninteractive simulation evaluation for CRT-genereted displaye (NUREG/CR-3556). Washington, DC: Nuclear Regulatory Commissior.

\section{ABSTRACT}

The United States Nuclear Regulatory Commission (USNRC) is sporisoring an ongoing research program to develop methods of assessing various types of computergenerated displays currently being implemented in nuclear power plant control rooms. The purpose of this report is to present a noninteractive simulation technique for the evaluation of computer-generated displays. Four safety parameter display formats were evaluated in two separate experiments. Three formats were evaluafed in Experiment 1 (STAR, BAR, METER). Two format were evaluated in Experiment II (BAR, P.T map). All formats contained top-level safety parameters minimally necessary for the safe operation of a pressurized water reactor at the Loss-of-Fluid Test (LDFT) reactor. Subjects of the experiments were current or former operators at the Loss-of-Fluids Test (LOFT) reactor. The results of this experiment have indicated that the noninteractive technique can be used to evaluate the detection and recognition of transients in safety parameter display evaluation. In addition, the data suggest thet given a reliable set of parameters and good human engineering that the graphical format of the display has negligible impact on performance. The implications of these results are discussed in terms of future work and display design.

\section{APPLICATION}

This report is intended to provide methods of evaluating various displays. Human factors engineers and control room design engineers may be able to apply the findings within this report. 
Blackmen, H.S., Gertman, D.L. \& Petersen, R.J. (1983). PBF task and training requirements analysia (Report №. EEG-REP-6274). Idaho Fells, ID: EG\&G Idelio, Inc.

\begin{abstract}
Task analyses were used to assist in identifying improvements needed in the training curriculum for selected positions at the Power Burbt facility (PBF). Four positions were examined: Experiment Power Reactor Operator, Experiment (EPRO-EX); Experiment Power Reactor Operator, Plant (EPRO-P); Experiment Power Reactor Operator, Console (EPRO-CD); and Shift Supervisor (SS). A complete position task listing and core of tasks defined in terms of (a) level of difficulty to perform, (b) severity of consequence if performed improperly, and (c) associated error probability were identified by aach position. The systems, academic, and administrative knowledge needed by job incumbents to perform each task was noted. Strategies for teaching the knawledge associated with these tagks are presented.
\end{abstract}

\title{
APPLICATION
}

This report may prove useful to indiviciuals involved with job or task analysis activities. It would be especially useful to DOE personnel. 
Bockhold, G., Jr. \& Rath, D.R. (1978). Performance measuremente system for training simuletore (Report No. EPRI-NP-783). Palo Alto, CA: Electric Power Research Institute.

\section{ABSTRACT}

In the first project pinase, the project team has designed, installed, and test-run on the Browns Ferry nuclear power plant training simulator a performence measurement system cepable of automatic recording of statistical information on operator actions and plant response. Key plant veriables and oper at ir acticns were monitored and anelyzed by the simulator computer for a selected set of four operating and casualty drills. The project has the following objectives: (1) to provide an empirical data base for statistical analysis of operator reliability and for allocation of safety and control functions between operators and automated controls; (2) to develop a method for evaluatior. of the effectiveness of control room designs and operating procedures; and (3) to develop a system for scoring aspects of operator performance to essist in training evaluations and to support operator selection research.

The performance measurement gystem has shown potential for meeting the research objectives. However, the cost of training simulator time is high; to keep research program costs reasonable, the measurement system is being designed to be an integral part of operator training programs. In the pilot implementation, participating instructors judged the measurement system to $b \varepsilon$ a valuable and objective extension of their abilities to monitor trainee performence.

\section{APPLICATION}

An automatic performance mezaurement system tested at Browns Ferry is discussed. Financial implications are also reviewed. 
Bolton, P.A., Faigenblum, J.M., Hope, A.M. \& Rankin, W.L. (1984). Simulator fidelity and training effectiveness: A comprehensive bibliography with relected annotations (NUREG/CR-3726). Washington, DC: Nuclear Regulatory Commission.

\begin{abstract}
This document contains a comprehensive bibliography on the topic of simulator fidelity and training effectiveness, prepared during the preliminary phases of work on an NRC-sponsored project on the Role of Nuclear Power Plant Simulators in Operator Licensing and Training. Section A of the document is an annotated bibliography consisting of articles and reports with relevance to the psychological sepects of simulator fidelity and the effectiveness of training simulators in a variety of settings, including military. The annotated items are diawn from a more comprehengive bibliography, presented in Section $B$, listing doctiments treating the role of simulators in operator training both in the nuclear industry and elsewhere.
\end{abstract}

\title{
APPLICATION
}

This report provides references which may be used by curriculum developers in developing guidelines for a variety of applications. The report itself is a bibliography with some annotations. 
Boone, M.P. \& Banks, hi.W. (1980). Human factora enqineering evaluation of the advanced test reactor contral room (Report No. EGG-SSOS-5288). Idatio Falls, ID: EGaG Ioiaho, Inc.

\begin{abstract}
This informal working clocument describes the results of a human engineering ev suluation of the Advanced Test Reactor (ATR) Cortinol Room. Problem areas of the control room ere identified, and specific recommendations are made for immediate and long-term improvements in man-machine interface design, human factors engineering of controls and displays, and overall control room design and configuration. Recommendations for future redesign include suggestions regarding use of control technology, provision of abnormal condition indicators, and reduction of unnecessary operator workload.
\end{abstract}

\title{
APPLICATION
}

Recommendations presented in this report are applicable to improvement, from a human engineering standpoint, of the control room design of the Advanced Test Reactor (ATR) specifically, and other process control operations -nd control rooms generally. 
Bott, T.F., Kozinsky, E, Crowe, C. \& Haas, P.M. (1981). Criteris for safety-related nuclear power plant operator ections: hitial pressurized water reactor (PWR) simulator exercises (NUREG/CR-1908). Washington, DC: Nuclear Regulatory Commission.

\section{ABSTRACT}

Nuclear piant control room simulator exercises for geven pressurized water reactor (PWR) events were conducted with ten control room teams. Operator performence was recorded by an automatic Performance Measurement System (PMS) and by subjective evaluation. Response times and error probabilities were estimated for selected actions. The effect of some experimental variables on operator performance is discussed. Application of the response time data to ANSI Standard N660 is included. The data collected will later be compared to field data being coilected for similar events in order to provide a basis for extrapalation of simulator data to actual operating conditions.

\section{APPLICATION}

A base of human performance data will be developed from the simulation experiments which can be used to establish criteria and standards, evaluate effects of key performance-shaping factors, and support sajety/risk assessment analyses. 
$\mathrm{CRT}_{8}, \mathrm{VDT}_{8}$, SPDS

Bray, M.A., Petersen, R.J., Clark, M.T. \& Gertman, D.I. (1981). Advanced diagnostic graphice (Report No. EGG-M-(19581). Ideho Falla, ID: EG\&G Idaho, Ine.

\section{ABSTRACT}

This paper is from a CSNI specialist meeting on operator training and qualifications, and reports NRC-sponsored research at Idaho National Engineering Laboratory involving evaluations of computer-based diagnostic graphics. The specific targets of current evaluations are multivariate data display formats which may be used in Safety Parameter Display Systems (SPDS) being developed for nuclear power plent control rooms.

\section{APPLICATION}

The purpose of the work is to provide a basis for NRC action in regulating licensee SPUSs or later computer/CRT applications in nuclear control rooma. 
Braoke, J.B. \& Duncan, K.D. (1983). A comparison of hierarchically paged and scrolling displays for fault finding. Ergonomics, 26, 465-477.

\begin{abstract}
The selection of test points when fault finding with a hierarchically paged dioplay is more efficient than when using a scrolling display. However, this difference is not found with more able subjects. An unexpected finding is that both displays seem to facilitate more consistent performance than that obtained when the operator's view of the system is unrestricted. The effect of restricting system information by a "window," as done by both types of display, is discussed in terms of strategies operators may adopt in consequence, in particular strategies to cope with memory loed.
\end{abstract}

\title{
APPLICATION
}

Efficient human information processing is essential to jobs where information is received through a CRT and time and decision making is of importance. 
Brown, C.M., Burklea, H.V., Mangelsdorf, J.E, Olsen, R.A. \& Williams, A.R., Jr. (1981). Human factors engineering standards for information processing oystems. Sunr.yvale, CA: Lockheed Missile \& Space Company.

\section{ABSTRACT}

This document presents human factors standards and guidelines for the human interface with computer systems. The general topics for which critería are presented include:

- Operating System Characteristics

- Display Format

- Language and Coding

- User Cantrol of the Interaction Sequence

- Online Cuvidance Capabilities

- Input Precedures

- Color Displays.

Each design principle is presented either as a standard or as a guideline. For standards, compliance is considered mandatory unless a specific exemption is granted by data base management. For guidelines, compliance is important for a good user interface, but may not be feasible in all situations.

\section{APPLICATION}

The goai of this document is to aid system designers of software, applications, and display formats in developing user-oriented, people-friendly systems. 
Brune, R,L \& Weinstein, $M_{0}$ (19RD). Procedures evaluation checklist for maintenance, test and calibration procedures (NUREG/CR-1369). Wabhington, DC: Nuclear Regulatory Commission.

\begin{abstract}
This document describes the checklist to be used by the U.S. NRC Office of Inspection and Enforcement inspectors for evaluating maintenance, rest, and calibration procedires and provides guidelines for its spplication. The procedures evaluation checklist is the praduct of a humen fectors study of nuclear power piant operations and procedures sponsored by the Office of inspection and Enforcenient. A detailed description of the study is provided in a coripanion document, Development of a Checklist for Evaluating Maintenance, Test and Calibration Procedures Used in Nuclear Power Plants, NUREG/CR-1368, SANDBD-7053.
\end{abstract}

As part of the study, abstracts of licensee event reports (LERs) submitted by all plants during the four-year period 1975-1978 were reviewed. The purpose of the review was to identify the specific kinds of procedures-related personnel error that have been assaciated with the performance of maintensnce, test, and calibration activities. A total of 751 LERs were attributable to procedural deficiencies. An analysis identified eight categories of performance errors resulting from procedural deficiencies.

\title{
APPLICATION
}

The checklist is intended to aid Office of Inspection and Enforcement inspectors in identifying procedural deficiencies that can lead to errors in performance. Each of the procedures avaluation criteria contained in the checklist deais with procedural characteristics related to one or more categories of performance error. The use of a procedure that is deficient with respect to these criteria can lead to errors in performance. 
Brune, R.L. \& Weinstein, M. (1981). Checklist for eygluating emergency procedures used in nuclear power plants (NUREG/CR-2005). Waahington, DC: Nuclear Regulatory Commission.

\section{ABSTRACT}

This document describes a checklist to be used by U.5. Nuclear Regulatory Commission Office of Inspection and Enforcement inspectors during their evaluation of emergency procedures. The ohjective of the checklist is to aid inspectors in identifying cineracteristics of procedures that can lead to operator performence deviationa. Methods of performing the evaluations are described and suggestions for applying the checklist to increase the effectiveness of the inspection process are made.

\section{APPLICATION}

This checklist could prove useful in a self-evaluation of current procedures or used as a step in the development process for new procedures. 
Burgy, D.C., Doyle, P.A., Barsam, H.F. \& Liddle, R.J. (1580). Agplied human factors in power plant design and operation. Columbia, MD: General Physics Cirporation.

\begin{abstract}
This textbook provides an introduction to human factors engineering principles and techniques and their application to power piant design end operation. Individual chapters degl with: recent government recommendations and future regulation relating to control room improvement; the outlcok for research funding; systems analysis in human factors engineering; performance evaluation techniques; effects of stress and fatigue on operator performance; the simulator as a training device and research tool; the role of hurnan factors engineering in training; assessment of equipment reliability and maintainability from a human factors engineering standpoint; evaluation of plant operability using human factors anelysis techniques; use of human factors engineering evaluation tools to determine and recommend control room improvements; and advanced power plant control room coricepts. A comprehensive bibliography lists source and reference materials relevant to this field.
\end{abstract}

\title{
APPLCATION
}

An introduction to the philosophical and technical bagis for applying human factors erigineering to the improvement of power plant control room design and operation. Potential applications include: design of training programs and plant systems; development of operational procedures; assessment and eveluation of training programs, equipment and syitems, and operational procedures; and use of simulators. 
Burgy, D.C., Newell, W.J. \& Van Cott, H.P. (1982, Octot:-:) Task analygis of nu-lear power plant control roorr. crews data collection approach end methodology. Peper presented at the Human Factors Society - 26 th Annuel Meeting, Seatile, WA.

\begin{abstract}
This paper describes the data collection approach and methodology used to conduct a task analysis of nuclear power plent control room crews. The objective of the research project, funded by the NRC Office of Nuclear Regulatory Research, is to provide task data for evaluating six ereas: (1) human engineering designs of new control rooms anc retrofitting of current control rnoms, (2) the numbers and types of control room operators required with requisite skills and knowledges, (3) operator qualification and training requirements, (4) normal, off-normal, and emergency operating procedures, (5) job performance aids, and (6) communications. The task analysis methodology used in this project is discussao and compared to traditional taek analysis and job analysis methods. A data collection approach is described which focuses on a generic structural framework for assembiing the multitude of task data that will be observed. Control room crew task data is observed and recorded wition the context of an "operatiry sequer-e." The data collection will be conducted at eight power plant sites by teams comprised of human factors and operations personnel. Plants were sampled according to NSS5 vendor, vintage, simulatos availability, architect-engineer, and control room configuration. The results of the data collection effort will be compiled in a computerized task data base. Preliminary discussion of illustrative examples to demonstrate suitability for data analysis will be presented.
\end{abstract}

\title{
APPLICATION
}

The information in this paper is useful for individuals or departments involved in task and job anelysis, Data collection approaches and methodology are discussed. 
BWR Owners Group.(1980, October). Control room gurvey chechlist. Included in manual prepared for Control Room Survey Workshop: Human Factore Engineerins; cunducted by General Electric Company.

\section{ABSTKACT}

This workshop provides a general intraduction to the Control Room Survey Program, including historica! background and HFE principles. A Contral Room Survey is conducted to meet $\mathrm{ARC}$ requirements fur eqfe'y review of design and procedures, identify modifications in the operator-control room interface to minimize the potontial for hiuman error, and determine an implementation plan for corrective action.

\section{APPLEÁATON}

The topics covered by this workshop can help train team riembers in the perfurmance of Control Room Survey, standardize survey methods, and organize aetual survey teams. 
Cakir, A., Hart, D.3., and Stewart, T.F.M (1980). Visual display terminels: A manual covering ergonomics workplace deaign, health and safety, task and organizations. New York: John Wiley \& Sons.

\section{ABSTRACT}

The rnain purpose of this report is to provide the designere, planners, and users of computer syatems with the most recent ergonomics knowledge ralevant to the design and selection of VDTs and VDT workplaces. This knowledge has been derived from a large number of experiments and field studies conducted by the present suthors and meny others in recent years.

\section{APPLICATION}

This book is useful to individuals designing or modifying VDT interfaces or workstations. Five different areas are covered: (1) how a VDT works; (2) the VDT as a systems component; (3) jight end vision; (4) ergonomics of VDT 3 ; and (5) VDT workplaces. 
Procedures

Canadien Standarda Aasociation. (1979). Qperations quality assurance for nuclear power plantB (CSA N286.5-1979). Rexdale, Ontario, Ceneda: Author.

\section{ABSTRACT}

This report applies to the operations of all safety-related systems and es;ipment. Described in the report are requirements of a quality agsurance program related to implementing the guidelines through detailed manegement of operations quality. The areas examined are policy, programs, review of programs, training, verification, operations, performance, and corrective actions. Emergency procedures are identifisd and procedures are prepared for implementation if needed.

\section{APPLICATION}

This report provides guidelines for quality control in nuclear power plants. Emphesis is placed on the operational aspects of quality easurante and orgenizational criteria. 
HFE (General)

Cerd, S.K., Moran, T.P., \& Newell, A (1983). The peychology of human-computer interaction. Hilladale, NJ: Lewrence Erlbaum Aesociates.

\section{ABSTRACT}

This book lays a scientific foundation for an applied psychology concerned with the human users of interactive computer systems An empirically-based cognitive theory of skilled human-computer interaction was constructed as a keystone for linking science and application. The theory is shown to be a consistent extension of the science of human information processing. It is also simplified into practical engineering models, which are the tools for designers to apply the theory.

\section{APPLICATION}

This nook is intended for persone interested in the topic of human-computer interaction - cognitive osychologists, computer scientists, system designers, human factors specialists, or man-machine engineers. 
Advanneed Contral Room

Clark, M.T., Banks, W.W., Blackman, H.S., \& Certmen, D.L. (1982). Advanced display concepte in nuclear control rooms. Manuseript submitted for publication.

\section{ABSTRACT}

Precursors necessary for the development of a full-8cale predictor display/control system have been under development since the mid-1940s. The predictor display itself has been available for use in manual control systems since 1958. However, the nuclear industry has yet to explore the uses and benefits of predictor aystems. This paper provides information on the application of this technology to the nuclear industry. The possibility of employing a simulation-based control oystem for nuclear plent systems that currently use conventionel euto/manual schemes is discussed. By employing simulationbased systems, a predictor display could be made available to the operator juring manual operations, thus facilitating control without outwardly affecting the overall control siheme.

\section{APPLICATION}

This paper describes options for applying predictor dieplay/control technology in nuclear power plant control raoms. 
Clerike, Mi.M., Garin, J. \& Preston-Anderson, A. (1981, October). Development ci u standerd methodology for optimizing remote visual display for nuclear maintenance tasks. Proceedings of the Human Factors Society - 25th Annual Meeting.

\section{ABSTRACT}

The aim of the present study is to develop a methodology for optimizing remote viewing systems for a fuel recycle facility (HEF) being designed at Oak Ridge National Laboratory (ORNL). An important feature of this design involves the Remotex concept - advanced servo-controlled master/slave manipulators with remote television viewing - which will totally replace direct human contact with the radioactive environment. The ${ }^{n}$ ore, the design of optimal viewing conditions iz a critical component of the overall man/machine system.

\section{APPUICATION}

This report presents a methodology for optimizing remote visual displays for nuclear maintenance tasks. The usefulness of this approach has been demonstrated by preliminary specification of optimal closed-circuit TV systems for such tasks. 
Cochran, D.J. \& Riley, M.W. (1982). An evaluation of handle shapes and sizes. Proceedings of the Human Factors Society - 26th Annual Meeting, 408-412.

\begin{abstract}
In many industries there are numerous hend tools in use which very considerably in handle size and shape with no apperent reasons. This research sought to investigate capabilities of males and females on two-thrust maximum foree tests, using various shapes and sizes of handles. To accentuate the characteristics of each size and shape, the force tests were conducted with the coefficient of friction between the hand and the handle surface reduced by the use of a disposable plegtic glove and the application of a slippery film.
\end{abstract}

\title{
APPLICATION
}

Persons interested in selecting the shape and size of a handle to be used in push/pull situations may find this eva!nation helpful 
Cochren, D.J. \& Riley, MW. (1983). An examination of the speed of manipulation of various sizes and shapes of handles Proceedings of the Human Factors 5ociety 27th Annual Meeting, 1, 432-436.

\section{ABSTRACT}

This research examined the effects of handle size and shape on two types of manual manipulation of handles. The first task evaluated was one in which the subject roteted a handle 1800 in his/her hand ane way, then reversed the rotation for $180^{\circ}$ in the opposite direction. On this task smaller handles could be manipulated faster. Also triangular hancles were significantly slower to manipulate than all other shapes tested except the square ones The second task evaluated the opeed of flipping a handle in the hand. For this task shape had no signifjeant effect on the time but size did. Once again, the smaller handles cruld be manipulated quicker then the larger ones.

\section{APPLICATION}

This is a useful guide in selecting size and shepe of handleg for takk-dependent hand tools. 
Other

Code of federal requlations: 10 - Energy, parts 0 to 199 (rav. ed.), Appendix A, Criterion 19. (1984). Washington, DC: U.5. Government Printing Office.

\section{ABSTRACT}

Criterion 19, "control room," of 10 CFR 50 (Appendix A) specifies the functions that a nuclear power plant control rorm and remate equipment must be able to perform with respect to safe operation of the plant end shutdown of the reactor. The control room must be able to maintain the plent in a safe condition under accident conditions, including loss-at-coolant accidents. Rediation protection must be provided under such conditions sufficient to preclude personnel exposures in excess of five rem whole body or pert body equivalent. Remara equipment must be provided with a design capability for both hot and cold shutdown of the reactor.

\section{APPLICATION}

This contains one of the federal regulations arising out of TMI-2, governing control room/remote equipment capabilities under bath normal and accident conditions. 
Comer, MK., Kozinsky, E.J, Eckel, J.5. \& Miller, D.P. (1983). Human rellability data bank for nuclear power plant operations. Volume 2: A data bank concept and system description (NUREG/CR-2744/2 of 2). Washington, DC: Nuclear Regulatory Commission.

\section{ABSTRACT}

The U.S. Nuclear Regulatory Commission (NRC) is conducting a research program to determine the need for a human reliability data benk unique to the nuclear induatry. Humain performance data conteined in such a data bank would be used to conduct humen reliability analysis (HRA) segments of probabilistic risk assessments (PRAs) of nuclear power plants.

\section{APPLICATION}

This report provides information on the human reliability data bank concept which may be tested in order to determine the effectiveness of the data bank cancept. Data includes storage by equipment standards, humen actions at the system leveh and individual control display levels. 
Corcoran, W.R., Church, J.F., Crosa, M.T., \& Porter, N.J (1981, April). Plant deaiqner's view of the operator's role in nuclear plant gafety. Paper presented at the ath Symposium on Training of Nuclear Faclity Personnel, Gatlinburg, TN.

\begin{abstract}
The nuclear plant operator's role aupporto the design assumptions and equipment with four functional tasks. He must set up the plent for predietable response to disturbances, operate the plant 80 as to minimize the likelihood and severity of event initiators, assist in accomplishing the safety functions, and feedback operating experiences to reinforce or tedefine the safey analyses assumptions. The latter tole enhances the operator effectiveness in the former three roles. The Safety Level Concept offers a different perspective that enables the operator to view his roles in nuclear plant aafety. This paper outlines the operator's role in nuclear sofety and classifies his tasks using the Safety Level Concept.
\end{abstract}

\title{
APPLICATION
}

This paper will be of interest to anyone involved in control room design or in the operator's role in nuclear safety. 
Maintenance \& Reliability

Cunningham, C.E. \& Cax, W. (1972). Applled maintainability enginees ing. New York: John Wiley \& Sons.

\section{ABSTRACT}

This book gives examples and methodology for each maintainability task, with a complete chapter for each numbered paragraph of the MIL-STD-470 standard. It will provide implementation guidenee for human factors specialists, maintainability engineers, and equipment design engineers.

\section{APPLCATION}

This book will provide implementation guidance to the maintainability engineer or organization delegated to the responsibility of compliance with the definition of maintainability as given in MIL-STD-721. 
CRTs, VDTa, SPDS

Danchak, MM. (1977). Alphanumeric displays for the man-process interface. Paper prosented a' meeting of Instrument Society of America, Niagars Falls, NY.

\section{ABSTRACT}

Display techniques used for printers are often carried over to CRTo with little regard for the drastic change in display medium. This paper attempts to recognize that change and offers suggestions for the intelligent design of such computer output. The basic characteristics of CRTs are surveyed and the attributes of alphenumeric characters discussed from the human standpoint. The characters are then integrated to form display pages that satisfy the operator's need for information. Recommendations are made for creating the mote traditional lists of alphenumeric information as well as the unusual layouts necessary for process control. All the recommendations are then summarized for easy reference and implementation.

\section{APPICATION}

The recommendations are summarized for the convenience of display designers. Briefly, the attributes of the operator, rather than the computer, must dictate the design of alphanumeric CRT displays. 
Danchak, M.M. (1981). Techniques for displaying multivariate date on cathode ray tubes with applications to nuclear process control (NUREG/CR-1994). Washington, DC: Nuclear Regulatory Commission.

\section{ABSIRACT}

Current methods of graphic display design uaing cuthode ray tubes depenc solely on the skill of the designer for choosing the eppropriate display technique. This report formalizes the selection process by describing 65 graphical representations and categorizing them according to the type of data they hest portray. The use of the diapiay is alao accounted' for by attaching a "use category," sush as a qualitative reading, to e sh techrique. The representation selection process is then formalized by asking the dezigner to consider both data and use. Recommendations for techniques al'e given for the various data types and uses. The method was applied to data for representation of the multivariate state of a typical nuclear power plent under both normal and transie.nt conditions. Nine alternative techniques were tested, three of which - Circular Profiles, Chernoff Faces, and Fourfold Circular Displays - vere considered very adequate for the date and use given.

\section{APPLCATION}

This report would be most useful to personnel working in data display, control room operations, and nuclear control room design systems. 
Danchak, M.M. (1982). Alarms within advanced display systems: Alternative and performance measures (N"JREG/CR-2776). Washington, DC: Nuclear Regulatory Commission.

\begin{abstract}
This study surveys five advanced alarm handling systems in industries having problems sirnilar to nuclear process control. The survey identifies the uritquenens of each system as well as features common to all. One such common feature is the use of alphanumeric alarm message strings displayed on cathode tay tubes (CRT). The study presents altel.atives for display of this information al.d dynamic techniques for the addition and deletion of alarms. A software package is described that incorporates the aiternatives and allows low-fidelity experiments to be coriducted in en snvironment that simuletes nuclear process control. The package was used to test static aspects of alarm CRTs and led to the conclusion that quantitative daia should come before qualitative data in alorm message strings. Methods for low-fidelity testing of displey dynamics aro also discusse:?
\end{abstract}

\title{
APPLICATION
}

This roport is intended to illustrate that a fundamental change is needed in the areas of human factors engineering and system evaluation. 
Das, B. * Grady, R.M. (1983). Industrial workplace layout deatgn. An applicetion of engineering enthrepometry. Ergonomic8, 26, 433-446.

\begin{abstract}
Workplece layout design perametere or dimensiono were determined mathematically by using the existing enthropometric date, for performing industrial takks u? sitting, standing and a combination of sitting and standing positions for the general male, femole and a combination of male and female operators and the individual male and female operatars for the 5th, 50th, and 95th percentiles. The nate were duly adjusted to account for the clothing, shoe and posture allowances. The reach dimensions were based on the most commonly used industrial operations which requira a grasping movement. Appropriate allowances ware provided to adjust the reach dimensions for other types of operations. The horizontal and vertical clearance dimensions and reference points for the horizontal and vertical clearances were established. For the determination of the normal working area in the horizantal plene, Squires' concept was recommended in preference to Farley's concept.
\end{abstract}

\title{
APPLICATION
}

Since the design af a workplece is related to performance, this peper presents a useful guide for proper ergonomic design. 
Deeb, J., Drury, C.G. \& Begbie, K. (1983). Handle positions in a holding task as a function of tesk heignt. Prnceedings of the Humen Factors Society - 27th Annual Meeting, 1 , $422-426$.

\begin{abstract}
Six handle positions in a two-hended container holding takk were tested with the container at floor, waist and shoulder heights. Hendle position effects on forces exerted, heart rate and psychophysical indices were large, comparable to a 25 percent change in container weight As in a previous study (at waist height only) and an industrial survey, handle positions providing both horizontal and vertical stability were better than symmetrical positions. Optimal angles of handle to container changed greatly with task height, giving almost horizontal angles at floor level and almost vertical angles at waist and shoulder level. implications for the design of handle cutouts on containers are discussed.
\end{abstract}

\title{
APPLICATION
}

Persons who are looking for optimal handle positions which cause the least exertion and discomfort can find a good reference here. 
Department of the Air Force. (198D). AFSC debign handbook 1-3: Humen factors engineering (3rd edition, Reviaion 1)(AFSC DH 1-3). Andrews AFB, DC: Headquarters Air Force Systems Command.

\section{ABSTRACT}

This handbook provides systern designers with h!man factors engineesing (HFE) design principles, information, guidence, and criteria; and estabishes a central source of HFE design data (any type of factual information that can be used as a besis for design decisions).

\section{APPUCATION}

Chapters include topics on human engineering, biomedical/life aupport, personnel and manning, training and training equipment, job performance aida, and test and evaluation 
Depsirtment of Defense. (1975). Military standardization handbook: Human factors engineering design for Army material (MIL-HDBK-759), Redstone Arsenal, AL: U.S. Army Missile Command.

\section{ABSTRACT}

The purpose of this report is to establish in handbook form general data and detailed criteria for humen fectors engineering applications in the design and development of Army material.

\section{APPLICATION}

This manual provides specifications for training curriculum, physical criteria, ergonamics, maintenance tasks, and a section on huriran factors in test and development evaluation. 
Department of Defense. (1977). Technical writing style guide (MIL-HDBK-63030-1 (TM)). Washington, DC: Author.

\section{ABSTRACT}

This guide complements the Technical Manual Writing Handbook (MIL-HDBK. $63038-1$ (TM)). The intent of this manual is to highlight and summarize the important elements of technical writing style as compared to literary writing. Also considered are the problem areas in which frequent mistakes are made in technic al writinc.

\section{APPLICATION}

The guidelines presented supplement official specifications by describing specialized applications of established principles, and by making orderly choices among approved variations in style. This guide could prove useful for individuals involved with writing procedures or developing Writer's Guides for procedures. 
Department of Defense. (1979). Humen enqineering requirements for military system8, equipment and facllitiea (Mll-H-46855B), Washington, DC: Author.

\begin{abstract}
This application establishes and defines the requirements for applying human engineering to the development and acquisition of military oystems, equipment, and facilities. These requirements include the work to be accomplished by the contractor or subcontractor in conducting a humen engineering effort integrated with the total sysiem engineering and human development effort. These requirements are the basis for including human engineering during proposal preparation, bystem analysis, task analysio, system design (including computer software design), equiprnent and facilities design, testing, and doc . mentation and reporting.
\end{abstract}

\title{
APPLLCATION
}

This handbook provides general information on humen engineering. This information would be useful to persons involved with system analysis, task analysis, system design, test and evaluation, documentation or reporting. 
Department of Defense. (1981). Military gtandardi Humen engineering design criterio for military systems, equipment and facilities (MIL-STD-1472C). Washington, DC: Author.

\section{ABSTRACT}

This standard establishes general human factore engineering criteria for design end development of military systems, equipment and facilities. The purpose is to present human engineering design criteria, principles and practices to:

a. Achiave required performance by operator, control, and maintenance personnel

b. Minimize skill and personnel requirements and training time

c. Achieve required reliability of personnei-equipment combinations

d. Foster design standardization within end among systems.

\section{APPLICATION}

This document provides design criteria for operations, maintainability, and testing. It also provides anthropometric data for the full range of women and men. 


\title{
Training
}

Department of Energy. (1983). Guidelines for job and tack analygis for DOE nuclear faclities (Report No. DOE/EP-O095). Washington, DC: Author.

\begin{abstract}
The guidelines are intended to be responsive to the need for information on methodology, procedures, content, and use of job and task analysis since the establishment of a requirement for position task analysis for Category $A$ reactors in DOE 5480.1A, Chapter Vl. The guide describes the general approach and methods currently being utilized in the nuclear industry and by several DOE contractors for the conduct of job and task analygis and afplications to the development of training prograins or evaluation of existing programs. in addition, other applications for job and task analysis are described including: operating procedures, development, personnel management, system design, communications, and human performance predictions.
\end{abstract}

\section{APPLICATION}

This document would be useful to persons, particularly DOE personnel, involved with job or task analysis. 
Department of Energy. (1984). Guidance for training program evaluation (Report $\mathrm{No}$. DOE/EV/10782-T1), Washington, DC: Author, Office of Scientific and Technical Information.

\section{ABSTRACT}

The subject guide was developed in response to the requirements contained in DDE Action Plan DOE/S-0007 to develop criteria and guidance for use b; the field for assessment and validation of reactor operator training programs at DOE Category $A$ reactors.

A general framework for the systematic evaluation of training programs for DOE Category A reactors is given. The evaluation process recommends self-evaluation by the operating contractor followed by a comprehensive review by the local field office. The guide also outlines good practices and evaluation factors in seven review areas.

\section{APPLICATION}

This report provides general guidance for producing training pragrams at DOE Category A reactors. 
DeSteese, 3G., Pelto, P.J., Rankin, W.L, Rideout, T.B. \& Shikiar, R. (1982). Humen factors affecting the reliability and safety of LNG facilities, Volume 1, control panel design enhancement (Report No. GRI-81/0106.1). Chicago: Gas Research Institute.

\begin{abstract}
The principal objectives of this project phase were to ( 1 ) expand the relevant human error probability (HEP) data base, (2) develop human factors (HF) design guidelines for LNG control panels, and (3) identify research needed to improve HF considerations in other LNG plant systems and aperations. The existing HEP data bese applicable to LNG facilitles was expanded to nine task categories containing human error rate information from analcgous activities in other industries. HF considerations in control room desigr wese ranked according to patential impacts on plant reliability and safety. An assessment of five representative LNG control panels showed signific ant HF design quality variations. Detailed HF design g'jidelines were developed for workspace, labels and location aids, controls, displays, annunciators, gas and flame detectors and emergency shutdown systems. Examples show HF enhancement resulting from application of these guidelines to existing panel designs and the layout of a model panel. A checklist with over 270 checkpoints was developed to facilitate control pane] design evaluation. This checklist and the guideline package are of potential practical value to utilities engaged in evaluating or improving HF design of control penels at individual plants. Thirteen projects are recommended to extend considesation of HF effects into other aspects of LNG facility design and speration.
\end{abstract}

\title{
APPLICATION
}

Persons interested in expanding their relevant HEP data base and developing hurian factors design guidelines for LNG control panels will find this a ubeful resource. 
DeSteese, J.G., Pelto, P.J., Rankin, W.L, Rideout, T.B. \& Shikiar, R. (1982). Human fectors affecting the reliability and safety of LNG facilities, Volume 2, control panel design quidelines and checklist (Report No. GRI-81/0106.2). Chicago: Gas Research institute.

\section{ABSTRACT}

The principal objectives of this project phase were to (1) exparid the relevent human error probability (HEP) data base, (2) develop human factors (HF) desigr guidelines for LNG control panels, and (3) identify research needed to improve HF considerations in other LNG plant systems and operations. The existing HEP data base applicable to LNG facilities was expanded to nine task categories cantaining humen errar rate information from analogous activities in ather industries. $H F$ considerations in control room design were ranked according to potentia! impacts on plant reliability and safety. An assesament of five representative LNG control panels showed significant HF design quality variations. Detailed HF design guidelines were developed for workspace, labels and location aids, controls, digplays, annunciators, gas and flame detectors and emergency shutdown systems. Examples show HF enhancement resulting from application of these guidelines to existing panel designs and the layout of a model panel. A checklist with over 270 checkpoints was developed to facilitate control panel design evaluation. This checklist and the guideline package are of potential practical value to utilities engaged in evaluating of improving HF design of control penels at individual plants. Thirteen projects are recommended to extend consideration of HF effects into other aspects of LNG facility design and operation.

\section{APPLICATION}

Persons interested in expanding their relevent HEP data base and developing human factors design guidelines for LNG control panels will find this a useful resource. 
Dowling, E., Bybee, R., Shulkla, J., Howland, R., Blomanes, B. \& Netlend, K. (1976). Assessment of technologies essential to the application of advanced oystems for process control (EPRI NP-640). Palo Alto, CA: Electric Power Research Institute.

\begin{abstract}
This report assesses the adequacy of certain underlying technologies which may be required for the successful design and implementation of "advenced computer supported control rooms". The assessment is based upon the answers provided by Babcock and Wilcox, General Electric and the Institutt for Atomenergi to a deteiled set of technical questions developed by EPRI (the questions and answers are documented in the appendices to this report). Among the technical areas addressed are: definition and justification of functional and design requirements; information assimilation techniques; operability; validation; reliability; and maintenance sapabilities. The rejort discusses the need for techniques to evaluate the impact of difterent design alternatives on aperator performance, the increasing importance of software validation to assure adequate availability, and the role of utility personnel in the support of hese systems.
\end{abstract}

\title{
APPLICATION
}

This report woulcs be useful to anyone interested in applying the technology of computer-based systems to advanced cantrol room design. 
Doyle, P., Lothar, S. \& Brewer, 5. (1983). An evaluation of the equipment tegging process in nuclear power stations. Proceedings of the Human Factors Society -27 th Annual Meeting, 1, 93-96.

\section{ABSTRACT}

The technique of "tagging" involves identifying inoperable equipment with small tags or other indications and maintaining records of equipment status. Operator reliability in the proper placement of tags is a function of training, good tagging procedures, adequate equipment identification techniques and tag design, among other things.

\section{APPLICATION}

This investigation of the tagging process ir nuclear power plants idencified problems in the areas of procedures, orientation aids, and labeling. 
Dutton, JW. \& Brown, W.R. (1981, April). Human factors in training. Paper preseniad at 4th Symposium on Training of Nuclear Facility Personnel, Gatlinburg, TN

\section{ABSTRACT}

The human factors concept is a focused effort directed at those activities which require human involvement. Training is, by its nature, an activity totally dependent on the human fector. This paper identifies several concerns significant to training situatione and discusses how human factor awareness cen increase the quality of learning. Psychology in the training arena is applied human factors. Training is a method of communication represented by sender, medium, and recejver. Two-thirds of this communications model involves the human element directly.

\section{APPLICATION}

This paper concerns increasing the quality of training by using humen factors concepts. 
Easterby, R, Kroemer, K.H.E \& Chaffin, D.B. (Edg). (1980). Anthropometry and biomechenics, theory and appllication. New York: Plenum Press,

\section{ABSTRACT}

This book is the result of a conference of which the aim was to (1) review the current statua of anthropometric and biomechanical data, (2) consolidate the theoretical and methodological advances in biomechanical studies, (3) to evaluate the role of computer-assiated techniques in the ecquisiton, presentation, and application of biomechanical and anthropon etric data, and (4) to provide a source boak by way of publishing comprehensive proceedings, for usu by researchers and practitlonera alike.

\section{APPLICATION}

This source book of comprehensive proceedings is of use to those interested in the anthropometrics and biomechanics of humens at work. 
HFE Requirements \& Studies

Edsberg, E. (1981). Human factors engineering in control system design. Halden, Norway: Institutt for Energiteknikk, OECD Hglden Reactor Projact.

\begin{abstract}
The human factors engineering professional is a new participant in planning and designing complex control systems such as nuclear power plant control rooms. The role of the oporating crew and the task allocation between crew and automatics is now an issue within the nuclear pawer communlty. The importance of crew qualificatione end of a well-de:igned organization as an infrastructure for control room operations is becoming evident. Computer technology is characterized by more accurate, more reliable, more digested, and above all more information to the crew on plent situations. HFE can make its contributions within many of these problem areas, but the major effort will have to be undertaken by the nuclear power industry itsolf, and its people.
\end{abstract}

\title{
APPLICATION
}

This report describes intelligent use of all the man-machine interaction possibilities without inundating the crew with new and aophisticated operator support aids. 
El-Bassioni, A.A., Hedrick, R.A., Starostecki, R.W. \& Penland, J.R. Review of standards and requirements affecting human factors in nucleer power plent control rooma. Oak Ridge, TN: Oak Ridge National Loboratory.

\section{ABSTRACT}

The study provides a ciesr and documented understending of the current requirements and design practices in the nuclear industry to: (1) evaluate and enhance the design of the control rcom to support the operator, and (2) develop operator aids to enhance the information provided to the operator. These purposes are approached by tabulating codea, standards, and design practices of the nuclear induatry as they relate to operator performance and reliability. In perticular, current requirements and practices of the IEEE, the ANS, and the NRC are examined and then plenned directions are identified.

\section{APPLICATION}

The results of this study provide the necescary data base for the new designers entering the nuclear control room design market. It also provides a iirst supportive step in evaluating the adequacy of these requirements Impacting the hisnan operators' interface with the plant. 
Electric Power Research Inatitute. (1982). Accident sequences for design, velidation and training - Safety parameter digplay system (Report No. EPRI-NSAC-40). Palo Alto, CA: Author, Nuclear Safety Analysis Center.

\section{ABSTRACT}

This report presenty a methodology for selecting simulated real-time accident sequences. It is based on the Zion probabilistic risk assessment. Three compact accident sequence sets that can be used at the various stages in implementing a Safety Parameter Display System (SPDS) are described. The study demanstrates that a limited number of sequences (29) is adequate to test the complete range of potential accidents and the optiors for their termination.

\section{APPLICATION}

The methodology presented c6n help select simulated real-time accident sequences that can be used as important tools in the development, validation, and operator training for an SPDS. 
Electric Power Research Inatitute. (1982). Evaluation of safety parameter display concepts (Volumas 1 and 2) (Report No. EPRI NP-2239). Palo Alto, CA: Author.

\section{ABSTRACT}

Two experimental concepto for a Safety Parameter Display System (SPDS) were evaluated to assess benefits and potential problems associated with the SPDS concept and its integration into control room operations. In Volume 1, the background of the SPDS is provided, and a description of the evaluation - including details of data collected and analyzed on crew responses to seven simulated accident conditions - is given. Volume 2 contains Appendix G, Protocols: Trensient Timelines, and Appendix $H_{3}$ Decioion Chaits.

\section{APPLICATION}

The contents of this report are useful as a model for the evaluation of dispiry systems and concepts. The two SPOS concepts themselves have potential applicability to the display of safety-related parameters. 
Embrey, D.E (1963). The use of performance shaping factors and quancified eypert judgement in the oyaluation of human reliability: An initial appraisal (NUREG/EF. 2986). Washington, DC: Nuclear Regulatory Commission.

\begin{abstract}
The first part of the report considers the naturs of human reliability assesgrnent, and the techniques currently emplayed. It is concluded that most approaches are limited by the availability of data. Approaches to the subjective assesament of error are surveyed. A particular technique which has been developed, the Success Likelihood Index Methodology (5LIM), is deseribed in detail, together with the practical steps for its implementation. The results from a trial application of a questionnaire designed to elicit judges' perceptions of the relative importance of performance shaping factore in determining humen reliability are analyzed. A revised form of the questionnaire is presented for future use. A pilot experiment to investigate the relationship between subjectively derived indices of success for six tasks and their objective probability of success is dascribed. The results indicate that SLIM has potential value as a predictiv s technic.ue. Some requirements for a program of research to produce a generally applic able methodology are set out.
\end{abstract}

\title{
APFIICATION
}

The report discusses human reliability assessment and the associated techniques. One technique, Success Likelihood Index Methodology (SLIM), is presented in dept\} Persans interested in or enticipating the assessment of human reliebility may find this report ugeful. 
Embrey, C.E., Humphreys, P., Rose, E.A., Kirwan, B. \& Rea, K. (1984). SLIM-MAUD: An approach to assessing human error probabilicies using atructured expart judgment (NUREG/CR - 3518). Washington, DC: Nuclear Regulatory Commission.

\section{ABSTRACT}

This two-volume report presents the procedures and analyses performed in developing an approach for structuring expert judgments to estimate human error prc'sabilities. Volume 1 presents an overview of work performed in developing the approach: SLM-MAUD (Success Likelihood Index Metliodology, implemented through the use of an interactive computer program called MAUD - Multi-Attribute Utility Decomposition). Vol Jme II provides a more detailed anaiysis of the technical issues underlying the approacis.

\section{APPLICATICN}

This repnrt describes the SLIM-MAUD method for estimating human error probabilities. This approach and the technical issues underlying th. approach are discussed. 
The Emergency Operating Procedures Implerrientation Assistance (EOPIA) Review Group. (1982). Emerger y Operating Procedures Implementation Asaistance Program (Report No. INPO Bz-013). Atlanta, GA: Institute of Nuclear Power Operations.

\begin{abstract}
ABSIRACT
The purpase of this pragram description document is to provite information that can be used by a utility in developing its approseh to implementing the new emergency operating orocedures (EOPs). The Energency Operating Procedures Implementation Assistance (EOPJA) Program identifies how assistance will be provided to the individual utility for use in implementing new EOPs. Members from the four nuclear industry groups participated in the evolution of this program: the Nuclear Reguletory Cummission, the owners group/NSSS vendors, INPO, and several individual utilities.

This document does not provide guidance and is for general information only. Four areas are identified in which development of guidance documents would assist the individual utility in implementing its EOPs. Assistance will be provided in the form af the companion documents to be published later.
\end{abstract}

\title{
AFPLICATION
}

This is the first document in INPO's Emergency Operating Pracedures Implementation Assistance (EOPIA) Raview Group series. This document describes the EOPIA opproest to the EOP upgrade. Together with the companion documents the report is uteful to ptants implementing Procedure Generation Package projects. 
The Emargericy Cperating Procedures Implementation Assistance (EOPIA) Review Group. (1902). Emergency Operating Procedures Writing Guideline (Report No. INPO 32-017). Atlanta, GA: Institute of Nuclear Power D:erations.

\section{ABSTRACT}

This Emergancy Operating Procedures Writing Guideline was developed by the Emergency Cperating Procedures Implementation Assistance (EOPIA) Review Group to assist individual utilities in developing or improving a plant-specific emergency operating procedure (EOP). Information is provided on improving or developing a plant-specific vrriter's guide for EOPs. Examples are provided of a writer's guide outline, a writer's guide and a procedure.

\section{APPLICATION}

This document provides useful information and guidance for developing plartspecific writers guides and writing emergency procedures. This is one document in INPU's EOPIA Review Group serjes. 
The Emergency Operating Procedures Implementation Assistance (EOPIA) Review Grcup. (1983). Emergency Operating Pracedures Implementation Guideline (Report No. INPO 82-016). Atlanta, GA: Institute of Nuclear Power Operations.

\section{ABSTRICT}

This document provides guidence to utilities for use in developing their impiementetion plans for emergency operating proceduses (EOPB). This document presents basic elements of an implementation plan for EOP, starting with the receipt of the emergyney operating procedure guidelines (EPGo). The following elements are presented and discussed:

- Shift characteristics

- Procedure systern and network

- Use of emergency operating procedure guidelines

o Writer's guide for EOPs

- EOF verification

- EOP validation

o Training

- Revision, review, and approval process

- EOP control

- Supporting documentation control

- Experience feedback.

\section{APPLICATION}

This document provides guidance for plants undertaking implementation programs for new EOPs. This is one document in INPO's EOPJA Review Group series. 
The Emergency Operating Procedures Implementation Assistance (EOPIA) Review Group. (1983). Emergency Operating Procerfures Validation Guideline (Report No. INPO 83.006). Atlanta, GA: Institute of Nuclear Power Operations.

\section{ABSTRACT}

The our:pose o" this quideline is co provide information that can be used by a utility in ieveloping its Emergency Operating Procedure (EOP) Validation Program. This document provides quidance in three major areas of an EOP validation program. These areas $\mathrm{dr}$ : the program objective, progrem evaluation criteria, and program process.

The program objective is to determine if the control room operators can menage emergenc; conditions in the plant usir. the EOPs. The program evaluation criteria are used to determine if the validation plinciples are satisfied. The program process supports the act wal performance evaluation.

This document is presented for guidance only. Its program is not intended to duplicate existing efforts in :OP review and approval processes. EOP validation as presented in this document is a performance evaluation that addresses whether t've EOPs are ue , le and cperatiounally correct.

\section{APPLICATION}

This document provides one perspective on the development of EOP validation programs. Differences between verification and validation are clearly explained. This is one document in INPD's EDPIA Review Croup series. 
The E- srgency Operating Procediaze Implementation Assistance (EOPIA) Review Group. (1983). Emergency Operating Procedures Verificetion Guideline (Keport No. INFO 83-004\%. Atlenta, GA: institute of iluclear Power Dperations.

\section{ABSTRACT}

The purpose of this guideline is to provide information that can be used by a utility in developing its Emergency Operating Procedure (EOP) Verification Program. This document provides guidance in three majer areas cf an EOP erification program. These areas are the program objective, program evalustion criteria, and program process.

The program objective is to determine that consistency has been maintained between the EOP6 and the EOP source documents. The program evaluation criteria are used to deterrnine if the verification principles are satisfied. The program process supports the actual comparative evaluation.

r.OP verification as presented in this document is a comparative evaluation that addresses whether the EOPS are written correctly and are technically accurate.

\section{APPUICATION}

This document provides one perspective on the development of EOP verification programs. Differences beiween verification and "aljdation are clearly explained. This is one document in INPO's EOPIA Review Group series. 
Enander, A. (1983). Performance and sensory aspects of work in cold enviranments: A review. Ergonomics, 27, 365-378.

\section{ABSTRACT}

Many people are occupationally exposed to cool or cold enviranments in which human performance and confort may be affected. Research results on menual function and other performance measures together with certain subjective effects relevarit to work in moderate cold are reviewed. The considerable individual differences in reactions to work in the cold are highlighted, and the difficulties in establishing relationships between physio!ngical measures of cooling, performance and sensory reactions are discussed. It is suggested that an integration of these three aspects is a necessary basis for understanding human resctions to work in the cold and for improving equipmerit, training and work routines.

\section{APPLICATRON}

This is a good guide for those interested in effects of cold or cool environments on performance. 
Engel, S.E. \& Granda, R.E (1975). Guidelines for man/displey interfaces (IBM Technical Report No. TR 00,2720). Poughkeepsie, NY: IBM Poughkeepsie Laboratory.

\begin{abstract}
This report documents a set of human factors guidelines relating to the interface oetween a user of an interactive computing nystem and a displey terminal connected to the system. Though intended primarily for the use of developers of coftware for an interactive system, many of the guidelines should be of interest to hardware developers. Areas covered include display frame layout, frame content, command languages, error prevention and recovery, response times and behavioral principles.
\end{abstract}

\title{
APPLICATION
}

The guidelines dealing with consistency of presentation, information presentation, and labeling are applicable across a wide range of man/terminal interfaces. The infortiation presented is use ful primarily to software developers. 
linlarged Nordic Cooperative Program on Nuclear Sutety. (1981, June). NKA/KRU project on operator training, contral room design end human reliability publications list. Nordic Coordinating Committee for Atomic Energy.

\section{ABSTRACT}

This publication summary is one of a set of documents which constitute the official reporting of the NKA/KRU project on control room design, operator training, and human reliability. While each of the technical reports has its own annotated bibliography, this collection lists all reports, working papers, etco, in chronological order by country for each of the three major areas of work.

\section{APPLICATION}

This is a comprehensive bibliography of source and reference materials relevant to the NKA/KRU project on control room design, operator training, end human reliability. 
HFE (Genersi)

Failure Analysis Assaciates. (1979). The role of personnel errors in power plant equipment reliability (Report No. EPRI AF-ID4I). Palo Alto, CA: Electric Power Resoarch Institute.

\begin{abstract}
This study is a preliminary quantification of the impact of personnel error on the avrilability of a cross-section of fossil fuel power plents. Information was collected from three sources: (1) personal interviews with knowledgeable representatives of nine utilities and staff of three vendors, (2) analysis of the trouble memos of two utilities, and (3) a survey of 38 utilities. Although the interviews revealed that personnel errors significantly affect equipment availability, specific daia are incomplete, emphasize equipment failure rather than human error, and differ greatly depending upon the information source. Written reports and survey data indicate in excess of 20 percent of all power plant system failures are probably the result of human error. The resulting loss in power generation capability is estimated to exceed 112,000 megewatt hours per averege 300 megawatt unit per year. Boilers and boiler tubes were the components reported to be most often affected by personnel errors, and operator errors are identified more often than maintenance errors. The specific root causes of major problem areas were not clearly identified in most cases, but utilities generally agree that improved training and, to a lesser extent, reduced personnel turnover and equipment designs which better consider human capabilities will reduce personnel errors.
\end{abstract}

\title{
APPLICATION
}

This is a review of the type of personnel errors in a cross-section of fossil-fueled power plants. Difficulties in specifying cause of equipment failures are also discussed. 
Felker, D.B. (Ed.). (1980). Document design: A review of the relevant research (Report No. AIR-75002-4/80-TR). Washington, DC: Americen Institutes for Research.

\section{ABSIRACT}

The overall goal in this review was to develop a document design research literature. The approach was to examine research from different disciplines tnat relate to document design. In addition, a chapter in the form of a case study that illustrates the deveiopment of an actual document design experiment was included.

\section{APPLICATION}

The information contained in this review would be useful to anyone preparing writer's guides, procedures, or ather documentation. 
Finlayson, F.C. (1977). Control room humen enginearing influences on operator performance. In Thermal reactor safety, Volume I. LaGrange Park, IL: Americen Nuclear Society.

\section{ABSTRACT}

This paper presents some of the major results of an evaluation of the effect of human engineering on operator performance in the control room. Primary attention is given to discussion of control room and control system design influence on the operator. Brief observations on the influerices of operator characteristics and job performance guides (operating procedures) on performance in the control room are also given.

\section{APPLICATION}

Under the abjectives of the study, special emphasis is placed on the evaluation of the control room-operator relatianships for severe emergency conditions in the power plant. Consequently, this presentation is restricted largely to material related to emergency conditions in the control room, though it is recognized that human engineering of control systerns is important for many other aspects of plant operation. 
Finnegan, J.P. (1980). Workshop proceedings: The role of personnel error in fossil fuel power plant equipment reliability (Report No. EPRI-AP-1470). Palo Alto, CA: Electric Power Research Institute.

\begin{abstract}
This warkshop was convened in response to emerging utility co.ıcern as the concluding part of the EPRI-sponsored study conducted by Failure Analysis Associates on "The Role of Personnel Errors in Power Plant Equipment Reliability." The purposes of the workshop were to (1) review the results of the study, (2) examine the nature of some personnel errors which affect fossil-fuel power plant equipment reliability, (3) establish priorities and goals aimed at error reduction, and (4) initiate technical planning of the necessary long-range efforts. The workshop began with presentations by utility representatives and human factors engineers. After general discussion, the attendees divided into three working groups. Various aspects of the problem were discussed and potential solutions were identified within each group and discussed with the general audience. Transcripts of each formal presentation and summaries of working graup recommendations are included.
\end{abstract}

\title{
APFIICATION
}

Persons interested in reducing personnel errors may find this paper helpful. 
Fischetti, M.A., Adam, J.A., Eisenhut, D.G. \& Horgen, J. (1984, April). TMI plus 5: Nuclear power on the ropes. Spectrum, 26-55.

\section{ABSTRACT}

The 1979 accident at the Three Mile Island (TMD) nuclear prent triggered a domino reaction that threatens the future of the U.S. nuclear power industry. This five-part special report covers (1) TMI cleanup, (2) the NRC's generation of a plan to alter existing nuclear reactors, (3) the improvements of nuclear hardware, (4) learning fron incidents at sites other than TMI, and (5) the remaining challenges.

\section{APPLICATION}

Those interested in a compact review of the last five years at TMI will find this a useful set of articles. 
Foley, J.P., Jr. (1973). Task analysis for job performence aids and related training (Report No. AFHRL-TR-72-73). Wright-Patterson AFB, OH: Air Force Human Resources Laboratory. (NTIS No. AD771001)

\section{ABSTRACT}

This peper presents several appects of task analyses for maintenance jobs when these analyses are used $a$ g beses for the developinent of Job Performance Aids (JPAs) and job-oriented training. An effort is made to standardize the task analysis process so that a true systems approach can be applied to the development of maintenance instructions and training for maintenance.

\section{APPLICATION}

This document is useful for guidarice for the development of job performance aids. 
CRTs, VDTh, SPOS

Computer-Easecisystems

Displays \& Controls

Frey, P.R. \& Kismer, R.A. (1982). A survey of metinods for improvina operator acceptance of computerized gids (NUREG/CiR-2586). Washington, DC: Nuclear Regulatory Commission.

\section{AESTRACT}

A review of the available litereture revealed about 70 papers that deal with acceptance problems in computerized systams. Two atteinpts are mede to define and measure the characteristics of a user-acceptable system in non-nuclear industries. The primary acceptence considerations during operations were found to be system availability and system calibration. Additional research was recommended to more accurately define the characteristics of a usf:r-acceptable system for nuclear power plant operators.

\section{APPLICATION}

This report describes factors related to user acceptance of computerized aids used in the nuclear power plant control room. 
Friar, D.E., Fowler, D.R. \& Brown, W.R. (1981, November). Development of a basic questionnaire for human factors application in nuclear power plant control rooma. Proceedings of the American Nuclear Saciety 1901 Winter Meeting, San Francisco, CA.

\section{ABSTRACT}

This paper analyzes the efforts of a study team in developing an assessment instrument. The principles fo: development of any questionnaire or control room survey are outlined first, and thein some of the actual processes used in the Fast Flux Test Facility reactor at Richland, Wasington, are described.

\section{APPLICATION}

One project goal was to provide other human factors specialists in the nuclear industry with a starting point for their own plant-specific questionnaires. 
Frogner, B. \& Rao, H.S. (1978). Control of nuclear power plants. IEEE Trang, Autom. Control, 3, 405-417.

\section{ABSTRACT}

The authors discuss applications, problems, trends, and their perspectives in the control of nuclear power plents, including interactions and objectives involved in obtaining operational flexibility and eafety. Areas where researchers developing control methods can contribute toward improved control design are outlined.

\section{APPLICATION}

Although this document outlines areas for further research contributions, the problems discussed should be of assistance to those involved in the control design of nuclear power plants. 
Fuchs, F., Engelschall, J. \& Imlay, G. (1981). Humen engineering quidelines for use in preparing emergency operating procedures for nuclear power plants (NUREG/CR1999). Washington, DC: Nucleat Regulatory Commiasion.

\section{AESTRACT}

This report presents recommendations aimed at improving the usability of emergency procedures used in nuclear power plants. The recommendations are based on established presentation principles and a review of typical deficiencies in current nuclear power plant emergency procedures. In support of the recommendations, a summary of these deficiencies and a discussion of the kinds of operator errors affected by procedures are included. The major recommendations are as follows:

1. Adopt a dusl-level procedure design.

2. Require a written specification governing procedure desigrn.

3. Employ human factors provisions in the design specification.

4. Require a written specification governing the procedure developinent prosess.

5. Continue to make maximum use of the analytical methods nzw employed.

6. Provide a means to heir ite plants comply with the specifications

\section{APPLICATION}

A model procedure is included to illustrate how the above recommendations can be implemented. A listing is offered of the kinds of human facters provisions that should be employed in the design specification. 
Procedurés

Fuchs, F., Engelenhall, J. \& binlay, G. (1981). Evaluation of emergency operating procedures for nuclear plants (NUREG/CR-ja75). Washington, DC; Nuclear Regulatory Commission.

\section{ABSTRACT}

This report documents the first of two tasks performed for the NRC relative to emergency operating procedures for nuclear power plants with a special emphasis on Loss of Ccolant Accident (LOCA) proceduras. Emergency procedures from nine plants have been evaluated. The recommendations regarding eacn plant's emergency procedurer were made in separate reports. In thls report, an analysis is made of problems common to emergency procedures in all nine plants. Pecommendations are advanced for impruvement of presentation style, level of detail, and administrative control.

\section{APPLICATION}

This ducurnent is useful to plants upgrading emergency procedures or writing $E \cap \mathrm{O}_{S}$ ior the first time. It provides infarmation and recommendations for common procedural format, style, ano content probleins. 
Fullerton, A.M., Peelle, E \& Reeo, J.H. (1982). An evaluation of the nuclear plant operator licensing examination: Final report (NUREG/CR-3458). Washington, DC: Nuclear Regulatory Commission.

\section{ABSTRACT}

This report contains findings and conclusions about the Nuclear Regulatory Commission's nuclear power plant operator licensing examination based on six months of field work in late 1981 and early 1982. This report includes chapters which describe and evaluate the examination systems as they existed at the time of the field work. There are also discussions of the concepts of validity and reliability as they relate to the control room operator examination, operator performance measures, and performance-shaping factors. The last half of the report focuses on what could and should be done to the operator licensing system. The report argues that any new examination must be based on task analysis and should incorporate methods for measuring operators' problem-solving ability in ill-defined situations. It is argued that the NRC needs to clarify whether their licensing examination is to be a test of minimal competence or a master test, whether the examination is to serve the selection function, and whether separate licensing tests are needed for ROs and SROs. The last chapter details a model of a new licensing process. Features of the process include validated selection procedures, a computerized basic knowledge examination, an apprenticeship period with documentation of performance, and a computerized, tailoted test to assess problem-solving ability and system understanding.

\section{APPUCATION}

This report can guide those interested in the validity and reliability of the NRC's nuclear power plant operator licensing examination. 
Gertmen, D.h, Blackman, H.S, Benks, W.W. \& Petersen, R.L (1982). CRT display evaluation: The multidimensional rating of CRT-generated displays (NUREG/CR. 2942). Weshington, DC: Nuclear Regulatory Commission.

\begin{abstract}
This report is one in a series evaluating various methods for determining the effectiveness of display formats and contains results from multidimensional rating of three cathode ray tube displays. Each display contained information regarding the status of nine safety parameters critical to safe operations at the Loss of Fluid Test (LOFT) reactor located at the Ideho National Engineering Laburatory (INEL). Certified LOFT operators evaluated three formats - bars, stars, and meters - as part of a multimethod display evaluation ongoing at INEL. Each of the six cognitive dimensions embedded in the rating scale are discussed in terms of their internal consistency and ability to differentiate between each of the three formats
\end{abstract}

\title{
APPLICATION
}

This report provides information which would be applicable in determining the effectiveness of various display formats and cathode ray tube displayso Information contained provides the status of nine safety parameters critital to safe operations at the Idaho National Engineering Laboratory reactor. 
Gertman, D.L, Bleckinan, H.S. \& Banks, W.W. (1982). CRT display evaluation: The multidimensional rating of CRT-qenerated dizplays (Report No. EGG-SSDS-5878). Washington, DC: Nuclear Regulatory Cornmission.

\section{ABSTRACT}

This report contains results of a multidimensianal rating of three cathode ray tube (CRT) generated displays. Each display contained information regarding the status of nine safety parameters critical to safe operation of the Loss of Fluid Test Reactor (LOFT), located at the Idaho National Engineering Laboratory (INEL). Certified LOFT operators evaluated three format types (bars, stars, and meters) as part of a multimethod approach to display evaluation. Six cognitive dimensions embedded in the rating acale are discussed in zerms of their internal consistency and ability to differentiate between each of the three format types. Preliminary findings suggest that two of the six dimensions, content integration (CD) and cognitive processing (CP), were able to distriminate between format types while satisfying the criteria of internal consistency.

\section{APPLICATION}

Findings of this research are applicable to the evaluation and use of CF $i$-based displays, and to the use of displays to indicate the staws of safety-related plant functions. 
Gertmen, D.I, Blackman, H.S., Gilinore, W.E., II \& French, D.L. (1983). ATR task training requirements and analysis (Report No. EEG-REF-6273). Idaho Falls, ID: EG\&G Idaho, Ine.

\section{ABSTRACT}

Task analysis techniques were used to assist in identifying improvements needed in the training curriculum for selected positions at the Advanced Test Reactor (ATR). Six positions were examined - Experiment Power Reactor Operator, Experiment (EPRO-EX); Experiment Power Reactor Operator, Console (EPRO-CO); Senior Reactor Engineer (SRE); Assistant Shift Operator (AS); Shift Supervisor (SS); and Process Control Operator (PCO). A complete position task listing and a core of tasks defined in terms of (a) level of difficulty to perform, (b) severity of consequence if performed improperly, and (c) associated error probability were identified for each position. The systems, scademic, and administrative knowledge needed by job incumbents to perform each task was noted. Strategies for teaching the knowledge associated with these tasis are presented.

\section{APPLICÁTION}

This report inay prove useful to individuals involved with job or task analysis activities. It would be especially useful to DOE personnel. 
Gertner, A., Irraeli, R. \& Cassuto, Y. (1984). Water and electrolyte balance in workers exposed to a hot environment during their work shift. Ergonomics, 27, 125-134.

\section{AB5TRACT}

This report investigated water and electrolyte balance in naturally heatacclimatized workers having free access to water and performing light to moderate work in a warm environment during their regular 8 hour work shift. The study was conducted at the metal workshops of two plents located in the south of Isreel in midsummer. Thirtytwo workers were studied in Sdom, an extreme desert, and 13 in Beer Sheva, a semi-arid zone. The average WBGT at the work area ranged from $\$ 60 \mathrm{C}$ at the begineing of the work shift to $290 \mathrm{C}$ at the end in Sdom, and $24^{\circ} \mathrm{C}$ to $250 \mathrm{C}$, respectively, ir Beer Sheva. Venous blood samples and bady weights were taken before, and after the work shifts. Three times during the work shifts, oral and skin temperatures were measured. The mean weighted skin temperatures increased $3.8^{\circ} \mathrm{C}$ in $5 \mathrm{dom}$ und $1.4^{\circ} \mathrm{C}$ in Beer Sheva during the work shifts, with a slight ir:crease in oral temperatures. No weight loss was detected at the end of the work shifts. Hematocrit values decreased at the end of the work shifts while the other variables measured in the blood and serum were unchanged. Blood and plasma volumes increased during the work shifts. The data indicate that water and electrolyte balance was maintained. It is concluded that when a naturally heat-acclimatized individual performs light to mocerate work (choosing his own work regimen) during his work shift in a warm environment, while having free access to drinking water and electrolytes, water and electrolyte balence is mainteined.

\section{APPLICATION}

This peper presenis information on the influence of heat stress on workers. Recommenclations are given. 
Goldnaber, G.M., Rogers, D.P., Lesnick, S. \& Porter, D.T, (1979). Auditing organizational communications systems: The ICA communication audit. Dubuque, IA: Kendall] Hunt Púslishing Company.

\section{ABSTRACT}

Chapter 4, Interprating the Audit, presents five audit tools with simple data and how to interpret these data. An interview guide, a questionnaire survey, and critical incidents are provided as instruments of measurement of organizational communications.

\section{APPLICATION}

This book describes an approach for assessing orgenizational communication through interviews and questionnaires that could be modified (with copyright permission) for use with nuclear facilities. 
Gnnzalez, W.R. \& Smith, D.L. (1984). A practical look at control penel enhancement, Nuclear Safety, 25, 227-237.

\section{ABSTRACT}

The accident at Three Mile laland has caused attention to be focused on human factors engineering concerns in the design of nuclear power plant control rooms and in control panels in particular. Examples from a control roorn review and enhancement task are described and discussed with reference to the need yor a careful interpretation of Section 6 of NUPEEG-0700 which of fers guidance for evaluation of control rooms but with very little retrofit information. Two Electric Power Research Institute studies that provide limited retrofit guidance are noted, and recommendations about further research are made.

\section{APPLICATION}

This report provides guidance and information which may be used in the area of human factors engineering in relation to nuclear power plant control room panels. 
Grandjean, E. (1980). Fitting the task to the man: An ergonomic approach (3rd ed.). London: Taylor \& Francis.

\section{ABSTRACT}

Emphasis is placed on the factors that affect people at work. This book pravides a summery of some important European ergonomics research that has not been available in English. The level of treatment is generally introductory.

\section{APPUCATION}

People who are involved in workplace or equipment design, human factors engjneering or related fields will find this bouk to be a practical and useful guide. 
Grandjean, E \& Vigliani, E. (Eds). (1980). Ergonomic aspects of visual display termingls. London: Taylor \& Frarcis.

\section{ABSTRACT}

Users of VDTs have encountered problems of many types, including physiological complaints due to constrained postures well as to eye strain, and poychological problems related to use of new working methods. In this book, the proceedings of an internationel workshop held in Milan in March 1980, these problems and methods for soitin? them are discussed. The contributiens fall into the following eight sections: (1) physical characteristics of VDTs, (2) visual functions, (3) visual impairments, (4) performence at VDTs, (5) postural problems, (6) psychosocial aspects, (7) practical experience, and $(B)$ ergonomic design and guidelines.

\section{APPLICATION}

VDTs are being installed in an ever-increasing varjety of workpleces: manufgcturing, industry, commerce, and adminiztration. Those interested in the design of VDTs ar the effects they have on workers will be interested in this book. 
Green, S.R. (1984). Realistic simulation of severe accidents in BWRs computer modeling requirements (NUREG/CRm2940), Washington, DC: Nuclear Regulatory Commission.

\section{ABSTRACT}

This report documents the results of an assessment performed at Oak Ridge Nationel Laboratory to determine the reactor and containment hardware, systems, and phenomena which must be modeled in realistic boiling water reactor severe accident analysis computer codes. The scope of the assessment is limited to BWR-4, 5, and o reactors and Mark I, II, and III containment systems. The report presents a concise review of the subject reactor and containment designs, together with a description of the reactor and containment systems which have the capacity to impact the outcome of severe accidents. The results of recent BWR probabilistic risk assessments are briefly discussed, and a detailed visualization of a BWR core melt accident is presented. Recommendations are made regarding the type of phenomena which should be madeled and the leyel of modeling sophistication required for various stages of the core melt accident. Finally, the current availability of the necessary models is discussed along with the associated model development priorities.

\section{APPLICATION}

This report is intended for review and assessment of reactor containment systems and designs. BWR risk assessment is presented along with a detailed core meltdown scenario. 
Maintensnce \& Reliability

Griffon, M. (1979). Human factors mathods for analyses of incidents for research upen human failures and their causes (NRC Translation 643). Washingtong, DC: Nuclear Regulatory Commission.

\section{ABSTRACT}

The incident anolysis method is divided into two phases:

1. Search for failure

2. Search for causes of human failures.

Failure is defined as finding a gap between the executed task and the task which would have been executed to avoid the occurrence of the incident. The method is applied to an incident of handling.

\section{APPLICATION}

In the long-term, this method of analysis should be used in a systematic manner for all incidents caused by human failures of execution. 
Haas, P.M. \& Bott, T.F. (1980, April). Criterla for safety-related nuclear puwer plant operator actions: A preliminary assessment of availoble data. Paper presented at 6th Advances in Reliability Technology Symposium and 3rd European Reliability Data Bank Seminar, Bradford, UK.

\section{ABSTRACT}

In the U.S., an effort has been underway for a number of years to develop a design standard to define when required manual operator action can be accepted as part of a nuclear plant design basis. To provide the necessary date base to support such standards and the necessary quantitative assessment of operator reliability, the NRC sponsored a study at Oak Ridge National Laboratory to develop the data base. A program of research using full-scope nuclear plant simulators and results that are correlated to field data was suggested. That program was recently initiated. The approach, results, and conclusions of the preliminary assessment are reported and the planned research program of simulator studies is summarized.

\section{APPLICATION}

This report would be helpful in preparing a date base of simulator studies to provide quantitative guidelines to develop a design standard for safety-related nuclear plant operator actions. 
Haas, P.M., Selby, D.L., Hanley, M.I \& Mercer, R.T. (1983). Evaluation of training programs and entry level qualifications for nuclear power ple.t control room perconnel based on the systems approach to training (NUREG/CR-3414, ORNL-TM6848). Washingtor, DC: Nuclear Regulatory Commission.

\section{ABSTRACT}

This report summarizes sesults of research sponscred by the U.S. Nuclear Regulatory Commission (NRC) Office of Nuclear Regulatory Research to initiate the use of the Systems Approach to Training in the evaluation of training programs and enti: level qualifications for nuclear power plent (NPP) persunnel. Variables (performance shaping factors) of potential impcrtarce to personnel selection and training are identified and research to riore rigorously jefine an operationally useful taxoiomy of these variables is recommended.

\section{APPLICATION}

A model of the Systems Approach to Training for use in the nuelear industry is presented. Checklists based on this model to assess training programs are also proposed. 
Haas, W.P. (1982). Upgrading of quality assurance programmatic guidance for operating nuclear power plants. Nuclear Safety, 23. 27\%-287.

\section{ABSTRACT}

As a result of analyois of the sccident at Throe Mile Island 2 (TMI-2) and experie:ıces at several construction sites for nucleer power plants, the Nuclear Regulatory Commission (NRC') ataff has rencluded thac certain quality assurance (QA) prorsammatic modificatione relative to existing guidelines should be made. These moditications are direcled toward upgrading and strengthening the QA function si operating n!calear power plants to improve its effectiveness in identifying and corjectirg operational deficiencies to protect the public hea'th and safety. The NRC has developed upgraded guidelines in specific QA programmatic areas and hes initiated their implemertation it TMI-1 (restart) end at several other oparating plants located near dE are to implemerrit the new guidelines at all nuclear plants unden design and construction and at recently' bujlt plants es well.

\section{APPLICATEIN}

Since quality assurance is of utmost importance in the nuclear power field, this paper contains some of the NRC's upgraded guidclines in specific $Q A$ programmeric areas. 
Hall, R.E. (1982). Post-event human decision errors: Operator action tree/time reliability correlation (NUREG/CR-3010). Washington, DC: Nuelear Regulatory Commission.

\begin{abstract}
This report documents an interim framework for the quantification of the probability of errors of decision on the part of nuclear power plant operators after the initiation of an accident. The framework can easily be incorporated into an event tree/fault tree analysis. The method presented consists of a structure called the operator action tree and a time reliability correlation which aseumes the time uvailable for making a decision to be the dominating factor in situations requiring cognitive human response. This limited approach decreases the magnitude and complexity of the decision-modeling task. Specifically, in the past, some human performance models have attempted prediction by trying to emulate sequences of human actions, or by identifying and modeling the information-processing approach applicable to the task. Although such modeling approaches can provide considerably greater insight into individual human behavior and the reasons for that behavior, this type of modeling for the full spectrum of relevant nuclear power plant tasks is extremely ambitious and goes beyond the requirements. The model developed here is directed at describing the statistical performance of a representative group of hypothetical individuals responding to generalized situations.

This document has the purpose of jntegrating and presenting work that has been under independent consideration and development by the three authors, and as such it represents an outgrowth of one recommendation of the 198I IEEE Standards Workshop on Human Factors and Nuclear Safety held at Myrtle Beach, SC. In order to bring together these ideas into the interim approach represented by this document, BNL contracted to the NUS Corporation and SAI for the services of Mr. J. Wreathall and Mr. J. Fragola, respectively. As a result of these contracts, two reports have been produced which describe the operator ackion trees method (NUS 14159) and the time-reliability correlation (SAI\# NY-R82-7-8(3)). These reports have been integrated into this document together with the separate development work that has been carried out $2 \%$ Mr. R.E. Hall of Erookhaven National Laboratory. The work described in the NUS Corporation and SAI reports is an outgrowth of a week-long meeting between the three authors held at Brookhaven National Laboratory and is representative of this 6-man-week effort of integration.
\end{abstract}

\title{
APPLICATION
}

This report describes an operator action tree methad and time reliability correlation. This information would be useful to persons interested in the quantification of the probability of errors of decision of nuclear power plant operators after the initiation of an eccid snt. 
Hartley, C.S., Levy, I.S. \& Fecht, B.A. (1984). Potential himan factors deficiencies in the design of local control stations and operator interfaces in nuclear power plants (NUREG/CR-3696). Washington, DC: Nuclear Regulatory Comimiseion.

\begin{abstract}
The Pacific Northwest Laboratory has completed a project to identify human factors deficiencies in safety-significant control stations outside the control room of a nuclear power plant and to determine whether NUREG-070D, "Guidelines for Control Room Design Reviews," would be sufficient for reviewing those local control stations (LCSs). The project accomplished this task by first reviewing existing data pertaining to human factors deficiencies in LCSs involved in significant safety actions; second, surveying LCS environments and design features at several operating nuclear power plants; and third, assessing the results of that survey relative to the contents of NUREG0700 . The study's conciusions are (1) a definitive list of safety-significant local control stations cennot be specified because power plant designs vary significentiy; ( 2 ) most, if not all, local control stations have design deficiencies that could be corrected by epplying human factors engineering principles; and (3) NUREG-0700 is generally applicable to LCSs but guidance is needed to address the design of manually operated valves and the design requirements of LCSs in extreme environmental conditions. Finally, the study recommends an approach for improving present LCSs to reduce the likelihnod that operator error will occur.
\end{abstract}

\title{
APPLICATION
}

This report provides a review of human factors deficiencies in control stations outside of the control room. Safety considerations are examined in conjunction with operator procedures. Human factors engineers and engineering psychologists may be able to utilize the information within this report. 
Helander, $M$ (Ed).(1981). Human factors/ergonomics for building and construction. New York: John Wiley \& Sons

\section{ASSTRACT}

Many of the factors that contribute to worker dissatiafaction and declining productivity in the construction industry directly involve problems in human elementa, ergonomics, and management. Reflecting the growing interartions between engineers and social scientists, this book is the first work to apply adv, nces in the study of human factors to the management of workers and work activities in the construction industry. Chapters of this book include: (1) accidents and consiruction site sefety, (2) company and work organization, (3) productivity measurement and improvement, (4) work satisfaction and improvernent, (5) the effect of environmental conditions on productivity, (6) ergonomic design of construction machinery, (7) physical and mental workload, (8) the effectiveness of training programs, and (9) affirmative action, minority rights and the construction industry.

\section{APPLCATION}

This book provides civil engineers, managers, and safety personnel with an improvec understanding of the importance of human factors in construction work, and offers practical guidelines, specifieally developed for the construction and building industry, for dealing with human problems in the work place. 
CRTs, VDTs, SPDS

Helander, MG. (1982). The VDT degian handbook (Report No. CRG-TR-82-014). Piscataway, N]: Bell Labotatories

\section{ABSTRACT}

This hardbook addresses the design of visual display terminal (VDT) workstations that use monochromatic cathode ray tubes (CRT) similar to the kind usad in television sets. The handbook is intended for persons within the Bell system who work with VDTs or who are interested in the human factors design of VDT workstations. The information is particularly important for the following situations: as a guideline for purchasing new equipment; for specification of the design of work places and illumination systems for new offices or offices that are remodeiled; to aid in the understanding of some important work environment problems and to promote communication of the problems

It is the ambition of these guiselines to ease the understanding of human factors design principles and inspire improvements in the working pnvironment.

\section{APPLICATION}

While this report was prepared for Bell Labs, anyone interested in VDTs or VDT workstations would find the inforination beneficial. 
Helander, M.G., Billingsley, P.A. \& Schurick, J.Mi. (1984). In A.S. Neal \& L. Strother

(Eds.), An evaluation of human factors research on visual display terminals in the workplece (pp. 55-130. Santa Monicd, CA: The Risman Factors Society.

\section{ABSTRACT}

This report describes a critical review of 82 human factors research studies on visual display terminals (VDTs). The areas of interest include visual discomfort (28 stıdies), anthropometry and jiomechanics (16 studies), work orgenization (9 studies), character and display design (21 studies), and lighting and reflectance ( 9 studies). The findings are summarized for each section individually.

Lack of scientific rigor has reduced the value of many of these studies. Especially frequent were flaws in experimenta! design and subject selection, bott: of which threaten the validity of results. In addition, the choice of experimental settings and dependent and independent variables often made it difficult to generalize the results beyond the conditions of the particular study. Admittedly, some of the research issues are difficult to study and would require substantial funding to investigate properly. Yet many studies would have gained much if appropriate field research methodologies had been used.

The studies on visual fatigue and postural fatigue nid not provide any affirmative answers to the issue of whether such fatigue is more frequent for VDT work then for tasks performed without a VDT. The otudies on work organization indicate that the work organization and job design factors may be more important than the VDT. The studies of workstation design, office lighting systems, and screen design provide some suggegtions that are useful for the design of VDT workstations.

\section{APPLICATION}

This report would be of interest to anyone in search of recent research an VDTs in the workplace. 
Hollnagel, E. (1981). The methodology of man-machine systems: Problems of verification and validation (Report No. RISD-M-2313). Roskilde, Denmark: RISO National Laboratory.

\section{ABSTRACT}

This paper provides an elementary discussion of the problems of verification and validation in the context of the empirical evaluation of designs for man-machine systems. After a definition of the basic terms, a breakdown of the major parts of the process of evaluation is given, with the purpose of indicating where problems may occur. This is followed by a discussion of verification and validation as two distinct concepts. Finally, some of the practical problems of ascertaining validity are discussed. The gene:al conclusion is that rather than rely blindly on $\theta$ well-established procedure or rule, $c$ : should pay attention to the meaningfulness of the aspects which are selected for observation, and the degree of systematism of the methods of observation and analysis. A qualitative spproach is thus seen as complementary to a quantitative approach, rather than antithetical to it.

\section{APPLICATION}

This report could be useful to individuals invalved in procedure generation projects or contral yoom design reviews. 
Hollnegel, E. Pedersen, O.M. \& Resmussen, 3. (1981). Notes on human performance analysis (Report No. RISO-M-2285). Roskilde, Denmark: RISD National Laboretory.

\section{AESTRACT}

This paper contains a framework for the integration of observation and analysis of human performance in nuclear environments - real or simulated. It identifies four main sources of data, and describes the characteristic data types and methods of analysis for esch source in relation to a common conceptual background. The general conclusion is that it is highly useful to combine the knowledge and experience from different contexts into a coherent picture of how nuclear operators perform under varying circumstances.

\section{APPLICATION}

This paper given a compact report an the snalysis of both research and training simulator performance and also analyzes routine event reports and complex incidents, based on in-plant interviews. 
HFE (General)

Hopkins, C.O. \& Snyder, H.L. (1982). Critical humen factors issues in nuclear power generation and a recommended comprehensive long-range plan. Procesdings of the Human Factors Societ: - 26th Annual Meeting, 692-697.

\section{ABSTRACT}

A comprehensive long-range human factors pian for nuclear reactor regulation was developed for the U.S. Nuclear Regulatory Commission by a Study Team of the Human Factors Society. This team identified and analyzed areas of human factors concern in nuclear power generation. It reviewed and evaluated current and planned humen factors activities and programs throughout industry and the NRC. The result was a recommended comprehensive human factori plan for the next ten years.

\section{APPLICATION}

This report provides information which can be used by utilities or vendors to develop their own long-range plans of applying human factors to nuclear power generation. 
Hopking, C.O., Snyder, H.L., Price, HE., Hornick, R.d, Mackie, R.R., Smillie, R.J. \& Sugarman, R.C. (1982). Critical human factors issues in nuclear power requlation and a recommended comprehensive human factors long-range plan: Volumes 1, 2, 3. executive summary (NUREG/CR-2833). Washington, DC: Nuclear Regulatory Commission.

\begin{abstract}
The report is presented in three volumes. Volume 1 contains an Executive Sumrnary of the 18-month effort and its conclusions. Volume 2 summarizes all known nuclear human factors activity, evaluating this activity wherever adequate information is available, and describes the recommended long-range (10-year) plan for human factors in regulation. Volume 3 elabarates upon each of the human factors issues and areas of concern that have led to recommendations in the long-range plan.
\end{abstract}

\title{
APPLICATION
}

These reports provide information which may be used in the nuclear engineering and human factors are日s, 


\title{
Treining
}

Hottman, S.B. \& Bateman, R.P. (1982). Task analygis of apent nuclear fuel operations technicians. Procoedings of the Human Factors Society - 26th Asnual Meeting, 873-877.

\begin{abstract}
This paper presents the results of a task enalysis of operations technicians at an independent spent fuel storage installation (ISFSI). Supervisors at the ISFSI were interviewed and a preliminary job analysis was used to determine required operator skills. Training, safety, operating documents and checklists were reviewed and tesk inventory forms were develaped with the help of ISFSI supervisors. Operations technicians were then interviewed and the task inventory forms filled out with information on task frequency, difficulty, hazard, time to complete, and error potential. These data were enalyzed to determine required operator skills and proficiency levels necessary for afe 15F 51 operation. The training and testing for certification necessary to verify the skills and proficiency levels were inferred from the data base and the Morris operation records.
\end{abstract}

\section{APPLICATION}

This paper contains information on job and task analysis. Methodology and results of a task analysis at an independent fuel storage installation are given. 
Hottman, 5.B., Bateman, R.P. \& Eiers, D.W. (1982). Analygis of training and certification of operations technicians at independent spent fuel storage installations (NUREG) CR+2712). Washingtön, DC: Nuclear Regulatory Commission.

\section{ABSTRACT}

This document presents the results of a task analysis and recommendations for the training and certification of operations technicians at independent spent fuel storage installations. It purpose is to provide a technical basis for initial and continuation training for operations technicians at Independent 5pent Fuel Storage Installations (ISFSIs). It also provides guidence for testing operations technicians to ensure that training objectives have been achieved.

\section{APPLICATION}

This report provides information which is pertinent to the training and certification of operations technicians at independent spent nuclear fuel storage ingtallation. 
Hsu, Y.Y. (1981). Some possible ways to improve nuclear power plant ingtrumentation. Nuclear Safety, 22(6), 728-737.

\section{ABSTRACT}

This article examines the aiequacy of nuclear power plant instrumentation on the basis of the lessons learned from the accident at Three Mile Island 2 and from some of the evailable advanced technology. The examination identifies two areas that could be improved - unambiguous indication and reliable data collection. it suggests that these two areas can be improved by (1) direct measurement of key parameters, (2) gitouping of information, (3) disturbance analysis, (4) self-verification of sensors, and (5) ability of the senscrs to survive in a hostile environment and to measure an extended range. Also reported are some of the ongoing research programs, including projects on in-vessel liquid-level measurement and un-line reactor surveillance systems, at the Nuclear Regulatory Commission.

\section{APPLICATION}

This report contains information on improving nuclear power plant instrumentation design and operation by unambiguous indication and reliable data colloction. 
Human engirnering quide to control room evaluation. Volumes I \& II Contributors: Stuart 0. Parsons; MPR Associetes, Lnc, General Electric; 5.t. Weiss; General Physics Corporation; BWR Owners Group; INPO; U.S. Nuclear Regulatory Commibsion; and General Atomic Group.

\section{ABSTRACT}

The following documents are included in the collection: HFE Control Room Review; Guidelines for Control Room Review; Contrni Roam Survey Project; MIT Course, Draft HE Checklist; BWR Owners Group Checklist; INPO Checklist; Computer Checklist; and Hif Review Plan and Checklists.

\section{APPLICATION}

These documents present various guidelines and checklists for use by NRC and the nuclear industry for control room design review. 
Illumineting Engineering Society. (1973). Americen ratlonal standard practice for industrial lighting (Al1.1-1973). New Ycrk: Author.

\section{ABSTRACT}

This stendard provides cciteria for industrial lighting requirerrents in various applications Luminescence measured in foot-candles and Dekaiux is applied in terr:s of contrast sensitivity, reflected glere, physical characteristics of the eye, quelity of illuminations, and daylight applications whel advantageous.

\section{APPLICATION}

This study is intended for applicstion in induitrial lighting requirements where spacific levels have been determined for various tasks. Human factors engineers and industrial psychologists may use this report in establishing a benchmark to evaluate lighting needs. This information may be of use during control room design review lighting surveys. 
Institute of Electrical and Electronice Engineers. (1980). IEEE standard criteria for safety systems for nuclear power generating stations (IEEE Standard 603-1980), New York: Author.

\begin{abstract}
This standard establishes minimum functional design criteria for the power, instrumentation, and control portions of nuclear power generating station aefety gystems. These criteria are established to provide a meens for promoting agfe prectices for design and evaluation of safety system performanee and reliability. However, adhering to these criteria will not necessarily fully establish the adequacy of any sefety Bystem's functional performance and reliability; nonetheless, omissior of any of these criteria will, in most instances, be an indication of safety system inadequacy.
\end{abstract}

\title{
APPLICATION
}

The criteria established by this standard apply to those systems defined as aafety systems and do nct necessarily apply to all of the safety-related systems, structures, and equipment required for complete plant safety. Although the scope is limited to safety systems, many of the principles may have applicability to equipment provided for safe shutdown, post-accident monitoring display instrumentation, preventive interlock features, or any other systems, structures, or equipment related to safety, or all of the above.

To determine those systems subject to these criteria, an analysis of the overall plant response to postulated design beais events must be performed. A detailed presentation of analytical techniques that can be used in such an analysis is contained in ANSI/ANS 4.11978, Criteria for the Preparation of Design Bases for Systems that Perform Protective Funetions in Nuclear Power Generating Stations Good engineering judgement must be exercised in this analysis to assure that adequate margins exist in the design without imposing unduly restrictive criteria such that the goal of protecting the health and safety af the public is replaced by one of protecting every plant component. 
Institute of Electrical and Electronics Engineers (1980). IEEE trial-use standard criteria for the design of the control room complex for a nuclear power generating station (ANSI/IEEE Standard 567). New York: Author.

\section{ABSTRACT}

This standard provides criterie for the design of the control room camplex for a nuclear power generating station. The emphesis is on the control room and its physical heusing itself. The control room provides an area where normal operations as well as emergency operations are initiated. In this capacity it is imperative that standards are utilized and meet safety features which protect personnel.

\section{APPLICATION}

This report provides guidelines and criteria for the control room complex in a nuclear fower generating station. 
Institute of Electrical and Electronics Engineers. (1977). IEEE recommended practice for the design of display and control facilities for centrel control rooms of nuclear power generaing stations (IEEE Standard 566-1977). Now York: fiuthor.

\section{ABSTRACT}

This document establishes guidelines to be used by power plant system designers in selecting information and control c'svices to be made available in the central control room $_{\text {f }}$ and in determining how and whert they shall be made available so that they can most rellably and quickly be used by the operator. The guide addresses the functional requirements of information systems, controls, and displays, but not the selection of specific devices or equipment. It does not apply to the physical design of the control soom enclosure or structures mounted therein.

\section{APPIICATION}

This document provides uniform guidelines for the functional selection, coordination, and organization of control and information systems in a nuclear power plant central cantrol room. 
Institute of Electrical end Electronics Engineers (1980). Dreft revision of IEEE Standard 560 (1977) - Criteria for design of nuclear power facility contral rooms New York: Author, Nuclear Power Engineering Committee.

\begin{abstract}
This document establishes criteria to be used by power plant system, equipment, and main control room designers in selecting information and control feetures to be made available to plant operators in the main control room, and the methods to be used to provide such features. These criteria reflect the application of human engineering principles as they apply to power plent men-machine interfaces during normal and abnornal plant canditions. This includes the requirements of iterative sysiemstic procedures to verify and validate the design process.
\end{abstract}

\title{
APPLICATION
}

The purpose of this document is to provide criteria for the functional selection, coordination, and arganization of controls and displays in a nuclear power plant control rcom, so as to optimize operator performance and minimize the potential for operator error. 
Institute of Nuclear Power Operations. (1982). The accreditation of training in the nuclear power industry: Criteria and procedures (Report No. INPO 82-011). Atlenta, GA: Author.

\section{ABSIRACT}

The evaluation of utility training involves accreditation and plant evaluatioris. Accreditation as described in inis document is intended to systematically evaluate and subsequently improve the training process used in individual utility training programs. Accreditation is complemented by INPO plant evaluations, which focus more directly on the performance of personnel in the plant, to ensure that training is prcducing the desired results and that plants are safely operated.

\section{APPLICATION:}

An accreditation self-evaluation process is included for use by a utility to compare its training and urganization programs to INPO Accreditation Criteria for the purpose of identifying strengths and weaknesses and problems and solutions. 
Institute of Nuclear Power Operations (1982). INPO/TVA pilot systems jeview report. Atlente, GA: Author.

\section{ABSTRACT}

This report of a pilot systems review project conducted by INPO and TVA is an attempt to develop an alternative to the guidelines for control soom design review (CRDR) published by the U.S. NRC (NUREG-0700). The objectives of the project were (1) to define the scope of the CRDR necessary to meet post-TMI requirements, (2) to define the depth of required analyses, (3) to provide examples of common human engineering techniques used to analyze system operations, (4) to estimate personnel/ equipment resources required for the conduct of the CRDR, and (5) to attempt to integrate the CRDR with other TMI-related requirements. The approsch utilized in this review emphasizes the improvement of plant operations under emergency conditions. Lnlike NUREG-0700, it does not require significant functionel analysis of operator tasks and system functions under emergency conditions; no analysis is performed for normal operations. Another difference is the omission of a control room inventory. A detailed analysis was conducted of two emergency resource systems, one simple and the other complex.

\section{APPLICATION}

This pilot project represents one approach to the conduct of a nuclear power plant control room design review, keyed to ensuring safe plant operation under emergency conditions. 
Training

Institute of Nucleas Power Operatione (1984). Training system development manuel. Atlantz, GA: Author.

\section{ABSTRACT}

The purpose of this manual is to provide guidance on applying the systems approach to training in the nuclear power industry. It has been designed for use by training managers, training supervisora, and the training staff at nuclear power plants and iraining centers. It describes an approach for establishing and maintaining training and qualification systerns based on actual job performance requirements. The manual illustrates the application of accepted management principles to the training process, with its success dependent on the effective management of the activities that are described.

\section{APPLICATION}

Implementing a training system development process requires two things - manegement commitment and qualified truining personnel. Training managers and supervisors should adhere to the principles of performance-based training. In order to manage or supervise performance-based training effectively, it is recommended that they have a working knowledge of this manual. 
Institutt for Energiteknikk. (1981). Computerized operation manual for safety technical specifications (HWR 30). Halden, Norway: Author, OECD Halden Reactor Project.

\begin{abstract}
The present report is part of the series of Haiden Work Reports (HWRs) which primarily are addressed to the Hadden Programme Group (the technical steering body of the Haldert Project) as a basis for its continuous review of the Project's research programs. The OECD Halder Reactor Project has developed a concept for computer assistance in the use of operational manuals for safety technical specifications. A prototype of a computerized operational manual was developed on the basis of this concept. Such a computerized operational manual was installed in the FOR5MARK-1 nuclear power plant in Sweden. This pilot installation, called the CST5 system (acronym for Computerized Safety Technical Specifications), was used for an on-site experimental investigation in order to test the main ideas of such a computerized off-line system and to gain some useful feedback from practice.
\end{abstract}

For this experiment parts of the safety systems were selected. A variety of user options were included.

\title{
APPUICATION
}

With this concept, the operator is given a quick and efficient comprehension of the consequences of changes in component status. In addition, the CSTS system makes it possible to simulate faults in connection with planning of maintenanice work. The system can be used for training and education of operation staff. 
Instrument Society of America (1979). Annunclator sequence and specificationg (Report

No. ISA-S18.1). Research Triangle Park, NC: Author.

\section{ABSTRACT}

This report provides information which may be applied in the standardization of annuncistor sequences and specifications. Various areas are examined throughout the whole system, and defined in terms of terminology, sequencing, order of sequencing, type, and application of various annunciators. The various types include illuminated, drop type, light boxes, recording, and seismic arnunciators. Standardization of the varied typea in relation to function, design and audible variance levels is examined.

\section{APPLICATION}

This report is uszful in control rooms or areas where annunciation is required. The varied listing provides brief guidelines towerd some meesure of uniformity. 
Joyce, R.P., Chenzoff, A.P., Mulligan, J.F., \& Mallory, W.J (1973). Fully proceduralized job performance ajds: Volume I - Draft millitary specifications for orgenizational end intermediate maintenance (AFHRL-TR-73-43). Wright-Patterson AFB, OH: Air Force Human Resources Laboratory. (AD-775 702)

\begin{abstract}
This volume specifies a model for sperifications for preparation of Fully Proceduralized Job Performance Ajds for the maintenance of Air Force equipment. The model has a unique feature of requiring a task analysis yielding certain intermediate products necessary for the development of maintenance data to be prepared in a standard format and submitted for review by the Procuring Agency. The aids to be developed are for the orgenizational and intermediate maintenance function.
\end{abstract}

\title{
APPUICATION
}

This report is useful for alding personnel with the development of job performance aids, especially in the maintenance area. 
Kammenn, R. (1979). The comprehensibility of printed instructions and the flowchart alternetive. Human Factors, 13, 183-191.

\section{ABSTRACT}

A few recent studies of open-book comprehension for printed instructions lead to the rule of thumb that such instructions will be undarstood correctly about two-thirds of the time. In the experiment reported here, two different flowchart formats were compared with standard peragraph instructions and were found to be superior in comprehension eccuracy and speed. The two-thirds rule and the flowchart effect were both sustained in comprehension testing in a subsequent field trial.

\section{APPUCATRON}

This report provides information which can be used in determining instruction procedures through either written instructions or flowcherts. 
Kershner, R.L., Gebhard, J.W., Silvermen, E.B., \& Pannel, G. (1982). An evaluation of nuclear power plent operator performence using a safety parameter display oystem. Proceedings of the Humen Factors Society - 26th Annual Meeting, 789-793.

\section{ABSTRACT}

An applied experimental project is presently underway to evaluate the Analog Safety Parameter Display System (ASPDS) and the Engineered Safety Features (ESF) developed by the Virginia Electric and Power Company (VEPCO). These systems and displays were designed in response to the U.5. Nuclear Regulatory Commission guidelines to eid reactor operators in the efficient performance of their duties. Humen performance during real-time control room operations with and without the ASPDS-ESF configuration were compared to test the efficecy of the systein. The date for all events is presently undergoing enalysis; a finel report will be available upon completion of this analysis project.

\section{APPLICATION}

Sorne backgrounù information for safety parameter display systems (SPDS) is presented here. 
Kisner, R.A., \& Frey, P.R. (1981), Summery of work on nuclear power plant crew function and organization (NUREG/CR-2587). Waghington, DC: ucleal Regulatory Commission.

\section{ABSTRACT}

This summary attempts to bring together in one reading the work on the nuclear power plent operatot's role carried out by Dak Ridge National Laboratory (ORNL) and several of its subcontractors. This work was \& pant of the research project, "Operational Aids for Reactor Operators," adminintered by ORNL and sponsored by the Nuclear Regulatory Commission (NRC). A list of these subcontractors is given with their respective contributing reports.

\section{APPLICATION}

This report discusses the role of the operator. Operations, training or staffing personnel may find the information useful. 
Knuth, D., \& Boyd, R. (1981). An independent gefely assesament of Department of Energy nuclear reactor facillities ems:zency planning and regotinge nivert No. DOE)(US-0013). Washington, CC: Department of Energy.

\section{ABSTRACT}

The Department o. Energy (DOE) has formed a Nuclear Facilities Personnel Qualification and Training (NFPOT) Committes to assess the implications of the recommendarions coritained in the Prosident's Commissiar. Report on the Three Mile Is' and (TMI) Accident (the Kemeny Commission report) that are applicablo to DOE's nuclear reactor operations. Thirteen DOE nuclear reactors were reviswed. The emergeney planning and response assessments of the facilities are besed on information provided by the individual operator organizations and/or cognizant DOE Field Offices. This refort indicates how these 13 reactor facilities measure $u$ in light of the Kemeny and other TMI-reiated studies and recommendations, particularly those that have resulted in upgrade:' Nuclesr Regulatory Commission (NRC) requirements in the arose of emergency plenning and response.

\section{APPLICATION}

This report assesses the DOE's nuclear reactor operations against the recommendations contained in the Fresident's Commission report on the TMI-2 accident. 
Kohl, C.A. (1903). Effects of shape and size of knobs on maximal hand-turning forces applies by females. The Bell Systems Technical Journal, 62, 1705.

\section{ABSTRACT}

Outside plant craftspeople use knobs to apply turning forces on clamp mechanisms that hold field equipment temporarily in place. A study wsi performed to develop a set of data that provide guidance for determining knob size and shape characteristics most appropriate for various outside plant working conditions. Forty female perticipents applied maximal isometric turning force to each member of a set of twenty experimental knobs that systemtically varied in shape and size. In half the trails the participants applied force with greased hends and in the other half used nonslip compound. In adjition, two arm-wrist positions were observed. In general, triangular knobs allow more hand torque to be generated and require significantly less material than square, pentagonts, hexagonal, or circular knobs of comparable size. However, this effect depends up on the arm-wrist position and grip conditions. A 3.5-inch turning diameter is desirable when both cost and performance are considered.

\section{APPLICATION}

With the increasing number of women performing jobs previously held by males, strength and size specifications for "tools of the trade" must be altered to accommodate both sexes. Here, the effecte of shape and size of knobs on maximal hand-turning forces applied by females are considered. 
Koukol, J.F., Lapin, E.E., Leverton, W.F., \& Pickering, W.F. (1980). Application of aerospace failure-reparting systeris to power plants (Report No. EPRI-N5AC-4). Palo Alto, CA: Electric Power Research Institutes, Nuclear Safety Analysis Center.

\begin{abstract}
This report provides the details of discrepancy/failure reporting sybzems used in NASA and DOD space projects. It describes how these data systems fit into the framework of a broad-based reliability program to ensure the success of complex systems. It is expected that some elements of the failure-reporting systems, which have been used so successfully by the aerospace industry, could be adopted by the nuclear power industry. The output from these reporting systems is an assential element of NSAC's efforts to continually upgrade nuclear sefety through currulative learning from plant-operating experience.
\end{abstract}

\title{
APPLICATIEN
}

The report would be of interest to anyone involved in implementing or administering reliability-related program, particularly in the area of data systems. 
Kubokewe, C., Woadson, W., \& Selby, P. (1969). Databook for human factors enqineers. Volume it Human engineering data. Volume Il: Common formulas, metrics, definitions (ivASA Report No. CR114272). Washington, DC: National Aeronautics and Space Administration. (NTIS No. N71-25943)

\section{ABSTRACT}

The information collected in this databook represents data most often used by practicing human factors specialists as determined by a survey of well-known practitioners of humen erigineering. The purpose of thiz handbook is to provide a convenient method for taking the most used reference information directly to a job remote from the specialist's regular bookshelf. Although it is recognized that such a collection may not be as complete as desired, an attempt has been made to cover as many topics as feasible within the context of a handbook. The included materials have been taken directly from other sources and in a few cases represent original data.

Volume l of the two-volume series contains typical humen engineering data useful in determining optimum design characteristics of equipment operated or maintained by human operatars and/or meintenance personnel. Volume Il contains formulas, nomographs, metrics, conversion tables, symbols, definitions and abbreviations and/or acronyms which may be required at some time during the project activities of typical human engineering specialists. This information, although available from other sources, often requires that the human engineer search through numerous texts, handbooks, specifications or guides in order to find what he needs.

\section{APPLICATTON}

This is a comprehensive source of human engineering data useful to designers or human factors specialists. The data contained is useful for applying to operational or maintenance tasks. Topics include anthropometry, equipment and component design, environmental conditions, human metabolic factors and human behavioral factors. 
Larsen, D.G. \& Robb, T.C. LOFT advanced control room operator diagnostic and digolay system (ODDS). Idaho Falls, ID: EG\&G Idaho, Inc.

\section{ABSTRACT}

The Lass-of-Fluid Test (LOFT) Reactor Facility in Idaho includes a highly instrumented nuclear reactor operated by the Department of Energy for the purpose of establishing nuclear sefety requirements. The results of the development and installation into LOFT of an Operator Dlagnostic and Display System (ODDS) are presented herein. ODDS is a computer-based graphice display system centered around a PRIME 550 computer with several RAMTEK color grephic display units located within the control room and available to the reactor operators. Use of computer-based coior graphics to aid the reactor operator is discussed. A detailed herdware description of the LOFT data system and the ODDS is presented. Methods and prow.erns of backfitting the ODDS equipment into the LOFT plant are discussed.

\section{APPLICATION}

This report would be of interest to anyone invalved in establishing and operating safety-related programs, perticularly those involving color graphic display units within the control room. 
Letbetter, D.G (1982). Design criteria for safer manual lifting by man and :ivili:.: Proceedings of the Human Factors Sociery - 26th Annuai Meeting, 503-507.

\begin{abstract}
Simplified degign oriteria are provided for two-handed, manual lifting by standing men and women, without selective assignment of personnel to specific material handling tasks. Besed on a 1981 NIOSH report, application of these criteria requires no knowledge of human anatomy, anthropometry, biomechanics, psychophysica, muscle fatig'se, cardiovascular capacity, or metabolic endurance. A person who can read and use simple graphs can quickly determine the maximum weight of a lieted object. The information needed is the horizontal grasp distence and the initial grasp height end lift distance of the object, plus the freguency and duration of lifting.
\end{abstract}

\title{
APPLICATION
}

This paper gives easy-to-read graphs for those who want to calculate the maximum weight a person can safely lift using two hands. 
Lindell, M.K. (1993). Analysis of emergency ataffing for nuclear power planta. Proceedings of the Human Factorg Society - 27th. Annual Meeting, 1, 184-186.

\begin{abstract}
Determination of staffing requirements for response to nuclear plent emergencies should be based upon task analysis in order to ensure that emergency functions can be performed in any type of eccidert. The method of analysis must recognize the differences between personnel performance in normal and emergency conditions and the limited information available for analysis of emergency tasks. A four-phase method is described that consists of generic enalysis (identification of general emergency functions and tasiks), situational analysis (definition of the characteristics of the classes of emergencies that can occur), quantitative analysis (determination of workloads, by position) and sensitivity analygis (examinetion of the degree to which changes in assumptions produce changes in required ctaffing levels).
\end{abstract}

\title{
APPLICATION
}

This report would be a useful guide for those interested in the staffing procedures for emergency situations in nuclear power plants. 
Lineberry, C.S. \& Bullock, D.H. (1980). Job aids. Englewood Cliffe, NJ: Educational Technology Publications.

\section{ABSTRACT}

This valume exemines the job aid options available to educators and trainers. Guidelines are offered on when, where, and how to use aids, and especially the explanation of the variety of forms that job aids can take.

\section{APPLICATION}

This book wou'd be useful for those involved in training or other areas where job performance aids are used 
Luma, S.F. Guidetti, R.P. \& Rowland, \& (1981, November). Palo Verde muclear genereting station control room humen factors atudy. Procesdings of the American Nuclear Society - Winter Meeting, San Frencitco.

\section{ABSTRACT}

This report provides the rasults of a study made of the Palo Verda nuclear generating atation contral room. The objective of the study was to identify control room human fecture diccrepane'es using NUREG/CR-1580 guldellnes. The study focused on the need to involve plant systeme, control room designers, utility technical management, and human factors specialiste.

\section{APPLICATION}

This report is intended to be used by engineering staff and human factors specialist s interested in control room design review activities. 
HFE (Ceneral)

CRTo, VDTE, SPDS

Lutman, R.N., Petrick, W.P. \& Hallam, I.W. (1982). A primer on colomraphic digplay systems for nuclear power plants (Report No. EPRI-NSAC-45), Pulo Alto, CA: Electric Power Research Institute, Nuclear Safety Analyais Conter.

\section{ABSTRACT}

This primer provides an overview of the technical lswes relative to the epplication of colorgraphic display systems in nuclear power plants. Key sections include the Nuclear Fegulatory Commission's (NRC) Emergency Response Facility (ERF) requirements, hardware celection criteria and evaluation, theory of operation, host and device independence factors, software engineering, human factors engineering, and serial and parailel interfaces Current technology is in a state of rapid evolution and this primer provides an upto-date assessment of key issues.

\section{APPLICATION}

This primer is intended to be a reference source for utility engineers responsible for the sybtem design and software engineering for modern, high-performance, computerbased grephic display systems 
Luxenberg, $H_{1} R$ \& Kuehn, R.L. (1968). Dicolay gysteme engineering. Now York: McGrew Hill.

\section{ABSTRACT}

This book contains background material whlch may be read by the precticing ceientist or engineer seeking en Introduction to display systems or by the worker already Ekilled in the area. The book includes much of the essential theoretical foundations of display systems, and technological reductions to practice.

Topics include photometry, colorimetry, image analysis, optics, CRTs, recording media, film-based production systems, lights, lasers, and laser holography.

\section{APPLICATION}

This book contains background material pertinent to displays. Theoretical foundations are presented also. 
Mackay, C.J., \& Bishcp, C.M (1984). Occupational health of women at work: some humen-factors considerations. Ergonomics, 27, 489-498.

\section{ABSTRACT}

Although still concentrated in a narrow range of activities (as compared to men), women are increasing their share of the overall labor force and there is a growing trend toward employment in occupations previously dominated by males. The health of wornen at work may bennefit from the self-esteem and sense of accomplishment which wark can bring or may suffer from the siresses of which work may impose. This papor discusses such effects on the physical and mental well-being of women at work from a number of perspectives.

\section{APPLICATION}

Given the increasing number of women in the workforce, this article reviews possible human factors considerations in the areas of occupetional health hazards, anthropometric differences, muscular strength/endurance, and mental health. 
Maddax, M.E (1983). The Interpretation of human factors $C$ sign criteria for nuclear power plant control room reviews. Proceedings of the Human Factors Society -27 th Annual Meeting, 1, 23-27.

\section{ABSTRACT}

As a result of the Three Mile Island-Lnit 2. (TMD) Bccident and subsequent investigations, all U.S. nuclear utilities are being required to review the control rooms in their nuclear generating plante for human fectors design adequacy. This paper presents a description of the ongoing process of applying human factors degign criteria from the military and aerospace arene to the raview and backfit aciivities in the nuclear utility industry.

\section{APPLICATHON}

Helpful in realizing a fundemental problem with guidance issued by the NRC and others is that much of the design guidance is not directly applicable to a review and backfit process such as control room and design reviews. 
Meduiox, M.E, \& Brickey, M,C. (1983). The integration of humen factors methodology into nuclear power plant control room reviews. Prcceedings of the Human Factors Society - 26th Annual Meeting, 654-658.

\section{ABSTRACT}

This paper briefly reviews the evolution of the Nuclear Regulatory Commission (NRC) requirements since the Three Mile island accident, and it describes a utility pilot study to demonstrate the usefulness of hurn'sn factors methods in meeting these requiremerits. This utility pilot study suggests that those human engineering $\mathrm{pr}$ blems likely to affect the ability of control room operators to complete emergency procedures should be assigned the highest level of priority for mitigation.

\section{APPLICATION}

This paper was written to lessen confusion among the utilities and the NRC regarding control room design reviews. 
Maliory, K., Fleger, s, Johr'ron, J., Avery, L., Welker, R., Baker, C., \& Malone, T. (1980). Human enaineering guide to control room eveluation. I. Control room avaluation process. Il. Human engineering quidelines idraft report NUREG/CR-1580). Washington, DC: Nuclear Regulatory Commission.

\section{ABSTRACT}

Task LD, Control Room Design, of NUREG-0660, the NRC Action Plen developed as a result if the TMI-2 Accident, specifies that the Commission's Office of Nuclear Reactor Regulation will require that operating reactor licensees and applicants for operating licenses perform a detailed contral room design review to identify and correct design deficiencies. The two-part report is a draft revision of the guidelines to be used in the detailed control room reviews. The guidelines and procedures of this report are based an human factors evaluations of nine nuclear power plent control rooms.

\section{APPLICATION}

The report is a suggested set of guidelines and procedures fer control room evaluation, and es such does not directly eddress all of tho design review factors specified in iask I.D of NUREG-0660. 
Martin, J. (1973). Design of man-computer dialogues, Englewood Cllffe, Nid: PrenticeHall, Inc.

\section{ABSTRACT}

This book is based on a course given at the IBM Systerns Research Institute. Man and computer must be able to communicaie with each other. Tine computer designer needs to take into consideration man's limitations in relation to tschnological innovatlons. The book addresses the topics of alphenumerle dialogues, scund and graphic dialogues, psychological considerations, operators without training, and implementation considerations.

\section{APPLICATION}

This book discusses problems and solutions for naive users of computer-based systems. The intent of the material is to make software/hardware specialists aware of user-induced design constraints. 
Metula, R. (1991). Effects of visual display units on the eyes: A blbliogrephy (1972-1980). Human Factors, 23, 581-586.

\section{ABSTRACT}

Visual display units (VDUs) have been reported to cause such difficulties as eyestrain, visual discomfort, and visual fatigue. In addicion, there are effects on visual accommodation as well es effects arising from contrast and glare sensitivity. This blbliography brings together in one place the widely dispersed literature on the effects of VOUs on the eyes.

\section{APPLCATION}

This bibliography provides various perspectives on the current researcn done on visual display units. It is a fairly comprehensive listing of recent articles concerning visual display units. 
HFE (Gerieral)

MeCormick, E.J., \& Sanders, M.S. (1982). Human factors in enginaering and design (5th en). New York: MaGraw-Hill.

\section{ABSTRACT}

This text is intended as a survey of the human factors field. Its major thesis is that the man made features and facilities of our civiazzation should be designed with due coneideration to the human use thereof. Topics include information input, human output and control, work space and arrangement, environments, basic human abilities and cheracteristics, and the effects of design features on human performance and human welfare.

\section{APPLICATION}

This textbook provides basic information on a variety of human factors engineering topics. Much emphasis is placed on the design effort. 
Maintenence \& Feliabillty

McKeithan, B.G., \& Kfoury, N.5. (1983). Increasing electric power plent productivity through maintenance management. Proceedings of the Human Factors 5ociety -27 th Annual Meeicing, 1, 576-580.

\section{ABSTRACT}

A literature search highlighting power plant maintenance objectives and problem areas was conducted. A method for performing a Human Factors Engineering Assessment of a piant maintenance department is aggested, in conjunction with various maintenance management techniques including time control, maintenance standards, maintenance prioritization, reliability management, information management automation, and the establishment of a Maintenance Planner position.

\section{APPLICATIOA}

This report would be of interest to persons developing or updating a plant maintenance department. 
Meese, G.B., Kok, R., Lewis, M.L \& Wyon, D.P. (1984). A laboratory study of the effects of moderate thermal stress on the performanee of factory workers. Ergonomice, 27, 19-43.

\section{ABSTRACT}

Nearly 1000 black and white, male and female factory workers were exposed in single-sex grnups of four, each group working a full shift and attending for one day only, to air ten peratures of $6,12,18,240 \mathrm{C}$ (cold series) and 20, 26, 32, 380C (hot series). All exposures were at low humidity. Clathing levels were fixed for the cold series and the hot serles. The exposures took place in a mobile climate chamber on the fectory site and the workers performed a series of tasks to simulate factory work. Significant effects of temperature were recorded and the implications for factory design are noted.

\section{APPUCATION}

Persons interested in the effect of thermal comfort on performance may find this paper of use. 


\section{HFE(General)}

Meljer, C.H, \& Gill, W.J. (1980, June). Operational aids to improve the man-machine interaction in a nuclear power plant. Proceedings of the American Nuclear Society Annual Meeting, Las Vegas, NV.

\section{ABSTRACT}

This paper addresses the Combustion-Engineering, Inc., (C-E) appryach to meet come of the lateat needs with operator alds to Improve the man-machine interfaces to monitor, control, and Jiagnose the plant during its normal and abnormal operation. In particular, the principles of a Critical Function Monitoring System (CFMS) are discussed in datail. CFMS is an aid to the plant operater to monito- and control a finite set of critical plent safety functione.

\section{APPLICATION}

For operating plants and $p$ lents in advenced stages of construction, C-E recommends installation of the CFMS in the control room as a separate, independent unit. For plants being designed or in early steges of congtruction, C-E views the integration of the CFMS into their NUPLEX 80 TM control room as the most ideal concept. 
Meijer, C.H., \& Safryn, F.J (1991). The treatment of alarms in power plants - a prectical discussion (C-E Document No. IPDR-BI-OC4). Windsor, CT; Combustion Engineering

\section{ABSTRACT}

This paper discusses a practical approach to the treatment of alarms in a power plant it addresses the Man-Process Interaction with alarms, the functional design criteria/goals for alarm systems and practical methods of alarm handling in currently operating as well as future plents.

\section{APPLICATION}

Those interested in a practical approach to the treatment of alarma in a power plant will find this of value. 
Meister, D. (198h). Humen Rellability. In A.S. Neal \& L. Strother (Eda), Humen factore review: 1984 (pp. 13-54). Santa Monice, CA: The Human Factors Society.

\section{ABSTRACT}

This survey reviews and assebses the human reliability (HR) literature under the following headings: Definition, Historical Review, The Importance of HR, HR Methodologies, Theoretical Assumptions, HR Studies, Taxonomic Factors, Data Bases, Critique of $H R$, end 5tatus and Future of HR. The review emphasizes the period from 1970 to the present. The relevence of HR to the human factors discipline is stressed.

\section{APPLICATION}

Those intercsted in human reliebility literature would find this review useful. 
Meister, $D_{n}$ \& R Rabideau, G.F. (2965). Humgn factors evaluation in sygtem development. New York: John Wiley \& Sans.

\section{ABSTRACT}

This is a book about how humen factors evaluation is performed during syatem development, with all of the limitetions and potentialities inherert in the system development situation. Topics include the system and system development, analysis and evaluation, human engineering evaluation of system products, system performance evalustion parameters, planning the performance evaluation, data collection and data enalysis methods, and human factors evaluation of production processes.

\section{APPLCATEON}

This book should be of use to anyone interested in examining the processes by which complex man-machine systems are developed and evsluated, including human engineers, and design and test engineers. 
Malber, B.D., \& Schreiber, R.E (1983). Engineering Expertice on thift in nuclear power plants: The foroign experlance (NUREG/CR-2952), Wastington, DC: Nucleas Regulatory Commiss!on.

\begin{abstract}
This report deseribes the practices of selected foreign countries with providing engineering expertico on shift in nuelear power plants The extent to which engineering expertise if made available end the alternative models oi providing such expertise are preserted. The implications of foreign practices for U.S. consideration of aiternatives are diceusead, with reference to the shift techrical advisor (STA) position and to a proposed shlft engineer position. The procedure used to obtain information on foreign prectices was primerily a review of the literature, including publications, presentatians, and government and utility reports There are two epproaches that are In use to make engineering expertica avai)eble on shift: (1) employing a graduate engineer in a line menagement operations position, and (2) creating a speclfic engineering position for the purpose of providing expertise to the operations staff. The comparisons of these two modeis did not indicate that ane system inherently functions more effectivoly than the other. However, the alternative modeis are likely to affect crew relationships and performence; labor supply, recruitment, and retention; and system implementation problems
\end{abstract}

\title{
APPLICATION
}

Alternatives to the shift terhnical advisor position, as currently precticed in foreign countrieg, are discussed. This report may prove interesting to operations personnel as well ea otaffing personnel. 
Merritt, R. (1980). Annunciatore meet a new standard. Inatrumento \& Control Systems 31-35.

\section{ABSIRACT}

This article provides an up-to-date look at annunciators and their development since the accident at the Threa Mile Island nuclear facility. A review of existing functions and sequence diagrams is precented. New technology in the field is diecussed in conjunction with applicetion and human factors principles.

\section{APPLICATION}

This article is intended to be of use to engineers and technical apport personnel. Various epplications are presented which illustrate the diversity of annunciators in applications relating to human factors. 
Morabl, J, \& Kraisg, K.F. 'Eds). (1981\}. Manned systems deaign: Methods, oquipment and applications New York: Plenum Press.

\section{ABSTRACT}

This book presents an overview of the curtent status of verious analytical and experimental methods relevent to this subject area. Contained in the book are the proceedings of a conference with the samie title. The papers are orgenized in four cections: concepts and strategies, analyticel approaches, measurement of performance, and simulator design and evaluation.

\section{APPLTCATEN}

This book contributes to a better understanding of this field of research and is a requisite volume for researchers and workere in industrial psychology end biomedical, nucleer, eerospace and chemicel engineering. 
HFE (Generel)

Moray, N (Ed). (1979). Mental workload, its theory and measurement. New York: Plenum Press.

\section{ABSTRACT}

Concentration and efficiency of performance are directly related to the concept of mental workload. The problems of too heavy or too light a load have been repeatedly enalyzed, generating an enormous amount of information in numerous models. This volume represents an interdisciplinary attemnt to gynthesize this material into a coherent summary that is both theoretically sound and practically applicable. Strengths and weaknesses of contemporary approaches to workload are described and new methods of measurement are critically assessed.

\section{APPLICATION}

Mental workload, from both the academic and appiied vlewpaints, are examined here for those winose work involves applying models of human behavior. 
HFE (Genaral)

Morgan, C.T., Cook, J.S., ill, Chipanis, A., \& Lund, M.W. (1963). Human engineerina guide to equipment design. New York: McGraw-Hill.

\section{ABSTRACT}

Tha primary emphasis in this handbook is in recommended design princlples and prectices in relation to general design problems rather than on the compilation of sesarch data.

\section{APPLICATION}

This book is to be used as a humen factors engineering handbook which the designer cen use to assist in design probleme. 
Morgenstern, Morl, Clausen, M.H., Foley, L.O., Levy, G.W., Myers, L.B., Rankin, W.L., \& 5hikiar, R. (1981). Guidelines for preparing emergency procedures for nuclear power plents (NUREG/CR-1977). Washington, DC: Nuclear Reguletory Commission.

\section{ABSTRACT}

In response to the Three Mile Island (TMD accident and the subsequent eveluation, the U.S. Nuclear Regulatory Commission (NRC) has published the TMI Action Plen. This fation Plan identifies the need to provide Emergency Operating Procedures thet treat the lower consequence/higher probubility emergencies which had not been addressed in the past, and the need to incorporate good human factors practices in these procedures.

\section{APPLCATION}

This document provides input for use in developing guidslines for writing Emergency Operating Procedures for nuclear power plante. 
Morse, G.L \& Swift, R.L (1982, April). Working safely in confined spaces Plant Engineering, 94-97.

\section{ABSTRACT}

Although testing the enviranment to be entered is necessary to ensure safe entry and work in confined spaces, it is only one part of a total program. After the environment hau been eveluated and the hazards identified, employees should follow certain procedures for entering and working within the space. This article outlines those procedures.

\section{APPLICATION}

This article is of use to those interested in implementing a safety plan for entering and working in confined spaces. 
Myers, L.B., \& Bell, A.J. (1984). Methoda for Implementing revisions to emergency aperating procedures (NUREG/CR-3632). Washington DC; Nuclear Regulatory Commisglon.

\section{ABSTRACT}

This report identifies factors which influence the effectlveness of training and implementation of revised emergency operating procedures (EOPs). The possible effects of negative trensfer of training are discussed. The report includes a summary of existing methods for implementing revisions to procedures based on interviews with plent personnel, a review of the training literature epplicable to the effect of previourly learned pracedures on learning and performance with tevised procedures (l.e. negative trensfer), and recommendations of methods erid schedules for implementing rovised EOPs.

\section{APPLICATION}

The information and results of this study are useful for facilities developing and revieving EOP implementation programs. 
Naval Air Syateme Command. (1980). Technical manual preparation guide for technical writers, edicore, end lllustratora - manggement and procedures manual (NAVAIR oj25-700). Warmineter, PA: Author.

\section{ABSTRACT}

This is a guide to assist technical manual personnel in the development of comprehenaive and usable tectinical manuals. The manual identlfies goals and obfectives for obtaining improved Navy Technical Manuel usability. The guide includes technical menuel design and development pheses, task development and technical manual organization, technical writing guldelines, llisstration guldelines, and comprehensibility essurance niticerie.

\section{APPLICATION}

The guide would be of interest for use by all technical manual prepering ectivitiea It includes methods and procedures essential for the development or update maintenance of usable and comprehensive documents. 
Nelson, W,R, (1964). Regponse trees and expert systems for nuclear reactor operations (NUREG/CR-363i). Washington, DC: Nuclear Regulatory Commisaion

\begin{abstract}
The United States Nuclear Regulatory Commission is aponsoring a project performed by EGö:G Idaho, Inc., at the Idaho National Engineering Laboratory (INEL) to evaluate different display concepts ior use in nuclear reactor control roome. Included in this project is the evaluation of the response tree computer-based decision aid and its assosiated displays. This report serves as an overview of the response tree methodolagy and how it hes been implemented as a computer-based decision aid utilizing color graphic displays. A qualitative assessment of the applicability of the response tree aid in the reactor control room is also made. Experience gained in eveluating the response tree aid is generalized to address a larger category of computer aids, those known as knowledgebased expert systems. General characteriatics of expert systems are discuosed, as well as examples of their application in other domains. A survey of ongoing work on expert systems in the nuclear industry is presented, and an assessment of their potential applicability is made. Finally, recommendations for the design and evaluation of computer-besed decision eids are presented.
\end{abstract}

\title{
APPLCATION
}

This paper is a helpful report to persons working in the areas of display design and evaluation. 
Nelson, W.R., Clerk, M.T. \& Bank8, W.W. (1981). Applicatione of Aunctional analysig : : nuclear reactor operations (NUREG/CR-1995). Weshington, DC: Nuclear Regulatory Commission.

\section{ABSTRACT}

The Loss-of-Fluid Test (LOFT) facility is used to demonstrate a funetional enalysis methodology. Two groups of procedures (for loormal cooldown and emergency decay haat removal) from the LOFT Plant Operating Manual (POM) are analyzed using the methodology. Example improvements to the procedures are presented, as well as general guidelines for upgrading operating procedures. Recommendations are made for potential applications of functional analysis in the nuclear industry.

\section{APPLICATION}

This report investigates functional anolysis techniques that can be used in the $n$ clear industry. Particular emphasis is given to the development and upgrading of operating procedures. 
Nuclees Rayulatory Commission,(1973). Reactor sefety study: An essessment of accident rir:m in 115. commercial nuclear power plants (NUREG-75/014). Weshington, DCi Authere

\section{ABSTRACT}

The Reactor Safety Study is a report describing the estimated accident risks to the prolic cr.mercial nuclear power plants of the type now in use. The study was directed by Frofes 30 Nisma, $C$. Rasmussen of the Massachusette Institute of Technology. The study compares the estimated risks fram nuclear power plants to those which result from other man-caurad and natural events. The appendices to the report describe the methodologies employect the analyges conducted and the results obtained. Included are detailed deseriptiens of the models developed to estimate the health effects and property damages which could be expected to result from nuclear power plant accidents.

\section{APPLICATION}

This report is use ful in providiny a comparison of potential risks at the nuclear level versus other man-made or natural events. This report would be applicable in the area of safety precaution and energency response to nuclear and natural disasters. 
Nuclear Regulatory rammission. (1979). TMI-2 lessons learned tesk force: Final report (NUREG-0585). Washington, DC: Author.

\section{ABSTRACT}

In its final report reviewing the Three Mile lsland accident, the TMI- $\mathbf{z}$ Lessons Learned Task Force suggests changes in several fundemental ospects of basic safety policy for nuclear power plants. Changes in nuclear power plant design and operations in tha regulatory process are discussed in terms of generel goala. The appendix sets forth specific recommendations for reaching these goals.

\section{APPLICATION}

This report is one of the first in-depth responses of the NRC to the impact of the TMI-2 accident on safety policy. It presents recommendations for improvements in l censing practices, personnel qualifications, staffing and manning procedures, performance verification/evaluation, control roum human factors, and design assessment. 
Nuclear Regulatory Commission (1980). Clarification of TMI ection plan requirements (NUREG-0737), Washington, DC: Author.

\section{ABSTRACT}

This document is a letter of licensees of operating power ieuctors and applicants for operating licenses forwarding post-TMI requirements which heve been approved for implementation. Following the eccident at Three Mile Island Unit 2, the NRC ataff developed the Action Plan, NUREG-0660, to provide a comprehensive and integrated plan to improve safety at power reactors. Specific items from NUREG-0660 have been approved by the NRC for implemertation at reactors. It should be noted that the total set of TMI-related actions have been collected in NUREG-0660, but only those items that the NRC has approved for implementation to date are included in this documient (NUREG0737).

\section{APFLICATION}

This report includes requirements information about schedules, applicability, method of implementation review, submittal dates, and clarification of technical positions for licensees of operating power reactors and applicants for operating licenses. 
Nuclear Regulatory Commission (1980). Criteria for preparation and evalustion of radioloqical emergency response plans and properedness in support of nuclear power plants (NUREG-0654). Washingiton, DC: Author.

\section{ABSTRACT}

This document is concerned with accidents at fixed commercial nuclear power reactors which might have impact on public health and safety. The purpose is to provide $\mathrm{B}$ common reference and guidance source for (1) state and local governments ani nuclear facility operators; ans (2) Federal Emergency Management Agerzv, NRC, and other Feveral agency personnel in the development of emargency response plans and preparedness in support of nuclear power plarits.

\section{APPLICATION}

Many of the planning e ments contained in this guide may be useful for planners in the vicinity of test and rese arch reactors, fuel processing plants, or other facilities using or producing large quantitios of radioactive material. 
Other

Nuclear Regulatory Commission. (1980). Inspection and enforcement manual. Washingto.7, DC: Author, Office of Inspection and Enforcenient.

\section{ABSTRACT}

This manuel contains basic policies and procedures that have overall applicatility to inzepection and enforcement progrems. Aiso inciuded is a cetegorized source of informetirn covering all phases of inspection and enforcement operations.

\section{APPLICATION}

Policy, procedures, inspection objectives, required scopes of inspection, and guidance developed for the Office of Inspection and Enforcement are provided. 
Nucrear Regulatory Commission. (1980). NRC uction plan developed as a result of TMI-2 gecident, Volume 1 (

\section{ABSTRACT}

This Accion Plen was developed to provide e comprehensive and integrated plen for the ections now judged necessery by the Nuzlear Regulatory Commission to correct or improve the regulation and operation of nuclpar facilities based on the experience from the eccident at TMI-2 and the official =tudies and in /estigations of the accident. Activitiea and programs of the NRC not related to the accident at TMI-2 are not deccribed in this Action Plan; they ere contained in the NRC Operating Plan. The cchedules and resources presented in this Action Plan and the NRC Operating Plan have been adjusted to try to optimize the increase in safety consiatent with the resourced availeb!e to the agency in fiscal years 1980 end 1981.

\section{APPLICATION}

This plan conteins the recommendations for specific chenges in operational safety; siting and design; emergency preparedness; practices and procedures; and NhC policy, crganization, and management following the TMI-2 accident. The plan also contains tutimates of the resaurces and schedule for NRC and the industry. to eccomplish the ecLions. 
Nuclear Regulatory Cummission (1981). Functional criterla for emergency regponse facilities (NUREG-0696). Washington, DC: Authar.

\section{ABSTRACT}

This report deciribes tha facilities and systems to be uaed by nuclear power plant licensees to improve responses to emergency situations. The facilities include the technical support center (TSC), on-site operational support center (OSC), and near-site emergency operations facility (EOF), as well as a brief discussion of the emergency recononse funetion of the control room. The data systems deseribed are the safety parameter display system (SPDS) and nuclear data link (NDL). Together, these facilities and systems make up the total emergency response facilities (ERFs). Licensees should follow tha guidance provided both in this report and in NUREG-0654 (FEMA-REP-1), Revision I for design and implementation of the ERFs.

\section{APPLRETION}

This docunent establishes criteria that the NRC staff intends to use in evaluating whether an applicant/licensee mep is the requirements of 10 CFR SO, Appendix $E$, Article IV.E.8 and Appendix A, GDC 19. The use of criteria different from those set forth herein will be accepted orly if the substitute criteria provide a basis for determining that the above-cited regulatrry requirements have been met. 
Nuclear Regulatory Commission. (1981). Guidelines for control room design reviews (NUREG-0700). Washington, DC: Author.

\section{ABSTRACT}

This regulation provides the guidance that the NRC staff believes should be followed to accomplish the control room design review described in NUREG-0660. The guitelines are based on NUREG/CR.1580 and NUREG-0659, with modifications as arggested and recommended in comments on these two documents. Compliance with these guidelines is not a requirement.

\section{APPLCATION}

Altheugh NUREG-0700 is not a substitute for statutory requirements, the approusches, methods, and reporting procedures provided can help ensure adequate human factors engineering considerations are included in control room design reviews. 
Nuclear Regulatory Commission. (1981). Human factors Bcceptance criteria for the safety parameter display gystem (dreft report) (NLREG-0835). Washington, DC: Author.

\section{AESTRAC'}

This report contains human factors engineering design revisw acceptance criteria developed by the Humen Factors Engineering Branch (HFEB) of the Nuclear Regulatory Commission (NRC) to use in evaluating designs of the Safety Parameter Display System (5PD5). These criteria were developed in response to the functional design criteria for the SPDS defined in NUREG-0696, Funetional Criteria for Emergency Response Facilities.

General acceptance criteria for displays of plant safety status information by the SPDS are developed. In addition, opecific SPDS review criteria correspanding to the SPDS functional criteria specified in NUREG-0696 are established.

These design review acceptance criteria define a basis for the NRC ataff's human factors review of a Safety Parameter Display System. These review criterie do not impose any new funntional design requirements.

\section{APPLCATION}

The purpose of this report is to identify design review acceptance criteria for the Safety Parameter Display System installed in the control room of a nuclear power plant. Use of computer-driven CRT displays is anticipated. 
Nuclaer Regulatory Commiseion. (1981). Staff supplement to the draft report on human enqineering quide to control room eveluation (NUREG-0659). Washington, DC: Author.

\section{ABSTRACT}

This supplement to NUREG/CR-1580 wes prepared by the NRC staff to provide (1) responses to comments on the draft quidelines, (2) sample checklists and corresponding humen engineering guidelines/acceptability criterib for analyzing operator-control room interfaces, and (3) draft systems review guidelinea.

\section{APPLICATION}

This document provides the planned procedures for evalusting licensee and applicant control room design reviews and for implementing control room design improvements. 
Nisclear Regulatory Commission. (1982). Cuidelines for the preparatim of emergency operating procedures: Resolution of comments on NUREG-0799 (NUREG-J899). Washington, DC: Author.

\section{ABSTRACT}

The purpose of this document is to identify the elements necessary for utilities to prepere and implement a program of Emergency Operating Procedures (EOPB) for use by control room persannel to aspist in mitigating the consequences of a broad range of accidents and multiple equipment failures. This document applies only to the EOPs so designated; it does not address emergency preparedness or emergency planning. It also represents the resolution of comments on NUREG-0799, "Draft Criterie for Preperation of Emergency Operating Procedures"

\section{APPLICATION}

This document epplies only to Emergency Operating Procedures and specifically does not address emergency preparedness or emergency planning. 
Nuclear Utility Takk Action Committee. (1983). Control room design review implementation quideline (Report No. INPO 83-026). Atlante, GA; institute of Nuclear Power.

\section{ABSTRACT}

The implementation guideline is divided into two distinct but complementary parta. The first part, the guideline portion, lists specific functional areas that should be addressed in somie form by utilities developing a CRDR program plan. The second part is ail example CRDR implementation program plan provided as the appendix.

\section{APPLICATION}

This CRDR implementatian Guideline has been developed by the CRDR NUTAC to assist individual utilities in developing their CRCR program plans in response to NUREG0737, Supplement 1 . 
Nuclear Utility Task Action Committee. (1983). Control room design review survey development quidelina (Report No. INPO 83-042). Atlanta, GA: Institute of Nucleer Power.

\begin{abstract}
The Survey Development Guideline is divided into three comfiementary parts. The introductory portion of the document describes the purpose and scope, defines the major terms used in the guideline, and describes briefly the methodology used, which is basically one of screening an existing set of items to find acceptable survey items.

The second portion contains an example set of the surveys, checklists, and questionnaires developed using this methodology. The purpose of this section is to illustrate the products produced by using the methodology and to assist member utilities by praviding CRDR surveys, checklists, and questionnaires that can serve as examples around which each utility may develop instruments specificallv tailored to their own control room survey. This is Appendix $A$ to the document.
\end{abstract}

The third portion of the document is a set of appendixes ( $B$ through $H$ ) containing items not included amang the control room survey items.

\title{
APPLICATION
}

This CRDR Survey Development Guideline has been developed by the CRDR Nuclear Utility Task Action Committee (NUTAC) to assist individual utilities in developing their CRDR program plans in response to NUREG-0737, Supplement 1. 
Nuclear Utility Tagk Action Committee. (1993). Control room deslan review task analygis quidoline (Report No. INPO 83-046), Atlanta, GA: Institute of Nueleer Power.

\section{ABSTRACT}

This document was written in response to a utiltty industry request for essiatance in the area of human factors in general and the CRDR in perticular.

It is intended for use by personnel performing a CRDR and is designed to assiat utilities in understanding and implementing that portion of their CRDR that requires the use of task enelysis. This document rontains a discussion of the rudiments of tasks and task analysis. Followig the introductory discussion are deseriptions of each phase required to implement the task analygis process in order to obtain the kinds of information necessary for the CRDR.

Appendixes to this document provide a sample task analysis procedure as it might be written by a utility, an example of the output of that procedure, and a reference list of NUREG-0700 Section 6 items that are most appropriately addressed during the CROR task analysis.

\section{APPLICATION}

This CRDR Task Analysis Guideline has been developed by the CPDR NUTAC to assist individual utilities in developing their CRDR program plans in response to NUREG. 0737, supplement 1 . 
Niclear Utility Task Action Committee. (1983). Human enqineering principles for control room design review (Report No. INPO 83-036). Atlanta, GA: hatitute of Nuclear Power.

\section{ABSTRACT}

The intended use for this documient is to help assess whether particular aspects of a nuclear control room that have been identified as HEDs can still fulfill the design principle for that particular item. This document conteine besic human engineering principles grouped into sections related to nuclear power plant control roorns Each principle is followed by a short explanation, $a$ list of references that can be consulted for catailed criteria related to that referenes, and examples of methads that might be used to cupport that principle. A cross-reference guide to NUREG-0700, Section 6, is provided as an appendix to this document.

\section{APPLICATION}

This document was written in response to a utility industry request for assistance in the area of human fectors in general and the CRDR in particular. 
Oak Ridge National Laboratory. (1981). Specification and verification of nuclear power plant training simulator response characteristice Part 1: Summary of current practices for nuclear and non-nuclear simulators (NUREG/CR-2353). Washington, DC: Nuclear Regulatory Commission.

\section{ABSTRACT}

This report reviews the methods and practices of the nuclear industry for apecifying and verifying the performance characteristics of simulators used to train nuclear power plant operators, it also reviews the training simulator methods and practices of selected non-nuclear industries (in particular, the civilian and military aircraft industriee) and compares them with those of the nuclear industry. In addition, it identifies non-nuclear methods that might be profitably adopted by the nuclear industry and perhaps included in - simulator standard endorseo by the Nuclear Regulatory Commission. Final conclusions and racommendations are discussed in a compenion report (NUREG/CR-2353, Volume 2; ORNL/TM-7986).

\section{APPLICATION}

This report reviews methods and practices used for specifying and verifying performence characteristics of simulators used to train nuclear power plant aperators. Non-nuclear industries may be able to utilize these procedures in other simulator applicetions. 
Oleen, R.A. (Ed). (1981). Handbook for design and use of visual display terminals Sunnyvele, CA: Lockheed Missile \& Space Compeny, Inc.

\section{ABSTRACT}

This hanobook concentrates on workstations with video of other displays and $a$ keyboard. It provides informetion on work environments and aids in the selection of display hardware. The needs of people using the displays are discussed, along with guidelines, rules, checklists, and tables for planning purposes Further sources of information are also listed.

\section{APPLEATION}

This handbook is for people interested in effects of work on posture and health; supervisors with questions on workstation desigri; managers planning and coordinating wark areas; buyers selecting or specifying furnishings; designers of cunsoles, panels, and displays; data processing systems and equipment designers; office mansgters and word procesaing supervisors; and training and personnel services representatives. 
Olson, J., MeLaughlin, S.D., Osborne, R.N. \& Jackson, D.H (1984). An Initial emplrical analysis of nuclear power plant orcanization and ita offect on safety performance (NUREG/CR-3737). Washington, DC: Nucleer Regulatory Commissiun.

\section{ABSTRACT}

This report contains an analysis of the relationahip between selected aspects of orgenizationel stucture and the safety-related performance of nuclear power plants. The report atarts by identifying and operationalizing certain key dimensions of orgenizational otructure that may be expected to be related to plant asfety performance. Next, Indicators of plent safety performance are created by combining existing ferformance measures into more reliable indicators. Finally, the indicators of organizational structure are related to the indicators of plant safety performance using corralational and discriminant analysis. The overall results show that pients with better developed coordination mechanisms, shorter vertical hierarcties, and a greater number of departments tend to perform more safely.

\section{APPLCATION}

This study may provide nuclear power plari: peroonnel with a better understanding of the relationship between orgenizational structure and sefety-related perforinance. 
Ulson, J., Schreiber, R.E. \& Melver, B.D. (1984). Alternative approaches to providing eglneering expertise on shift (NUREG/CR-3785). Washington, DC: Nuclear Regulatory Cornmission.

\section{ABSTRACT}

This report represents the conclusions of a project studying the role of engineering expertlae on ehlft in nuclear power plantc. Using the present shift technical advisor (STA) position as the base cese, eeveral alternatives ware analyzed. On-shift aiternatives include the STA, the shift supervisor (SS), and the shift engineer (SE). The SE is degreed, experienced, trained and licensed as a Sanior Reactor Oparator. Some non-shift alternatives were also studied. These included a cedre of on-call engineers and specialists within ccntinual contact and easy raach of the plant, a technical system of phone and date lines linking the plant with a facility slmilar to en on-site technical support center, and a safety perameter display syster, (SPDS) to augment techuical upgrading of operator aids presently available. Potential problems considered in the arialysis of implementation of these alternatives included job content constraints, problems of crew acceptance, and problems of labor supply and retentlon. Of the considered alternatives, the SE and SS options appear superior to the current STA approach. The SE option appeers the easiest to implement and the most effective under varjed plent conditione. The SE may also sarve as liaison to off-oidia support facilities.

\section{APPLCATION}

The intent of this report was to study the role of engineering expertise on shifts in nuclear power plants. Areas of information were the shift engineer, shift technical advisor, and overall engineering expertise. 
Onodare, Ka, Miki, M, Nukada, K, \& Nakamura, H. (1992). Reliability manegement of nuclear power plant. 1982 Proceedings, Aimuyl Kellabllity and Mainiainahillity Syniposiun, 151-156.

\section{ABSTRACT}

Statistics show that the average freciuency of forced shutdo'wn of nuclear power plents is 6-9 times per plant year in the United States 3-4 in West Germany and about 1 in Jepan.

Although Japen seems to have reacined a good frequency, plent mar,ufacturera wish to improve this frequency by making morv rellable plants.

This paper describes several ectivitias of plant manu'scturer Hitachi, Lid, relating to the reliability management of nuclear power plants, such an stenderdization of design, ruliability classification of equipment, and raliability assessment methods.

\section{APPLICATION}

Since plant shutcown means loss of money, all plent personnel interestad in mainten:ance and reliability wouid find this article useful. 
HFE (General)

Parker, J.F., Jr., \& West, V.R. (Ed6.), (1973). Bioastronautics Data Book. Washington, DC: National Aeronautics and Spece Adminibtratlon.

\section{ABSTRACT}

This revision of the Bioestronautics Data Book was prepared in order to bring together the essentials of the large body of humen research information generated in recent years and to present it in a form suitable for engineers and othery concemed with the development and evaluation of modern systeme. This is an updating and expargion of an earilier document prepared for the Natinnal Aeronautiss and Space Administration in 1964 by Webb Associates. The revision was prepared under the guidance of Working Group 5 of the Committee on Hearing Bioacoustics and Biomechanics of the National Academy of Seiences.

\section{APPLICATHON}

This book is designed to be a source of human research information generated in recent years. It deals with a substantial array of content areas within the broed domain of life sciences and presents primarily that information deemed of value for system design and evaluation. 
Perria, HLL, \& McConville, J.T. (1981). Anthroporngtric data base for power plent design (Report No. EPRI NP.1918-SR, Special Report). Palo Alto, CA: Eloctric Power Research Institute.

\section{ASSTRACI}

The primary study objective is to develop anthropometric data based upon the men and women who operate and maintain nuclear powjer plants. Age, stature, and weight infermation were obtained by a questionnaire survey of current operator and maintenance personnel, and the data extracted from the questionnaires were analyzed to derive bodysize information for a number of anthropometric variables of interest to designers. Designers can significently increase both the aperationel and maintenance efficiency of future power plant workplaces by atilizing the data contained in this report.

\section{APPLICATION}

The availability of asch date will particularly help designers who in the pest eicher have not systematically utilized any formal date or who have been forced to rely on the use of anthropometric data compiled for ather populations. 
Fesulg, J.L. (1983). Stair safety and hendratl studies: methods, findinge and epplicationg to bullding rodes and standards. Proceedings of the Human Factors Society - 27th Annual Meeting, 2, 611-615.

\section{ABSTRACT}

Background information is provided on the problem of stair accidents and the soluticns being recommended as a result of research into stair use and design. Changes in building codes and standards began appearing in 1980; more extensi ; changes are now being discussed end will appear between 1984 and 1990.

\section{APPLICAIION}

Stair accidenta are the leading cause of injuries in buildings. Thote involved in stair design can find recommendaticns in this article. 
Pen, R. W., Miller, D.C., \& Feeher, C.E (1981). Evaluation of proposed contryl roum improvements through analysis of critical ogerator decisians (Report No. ETRL-NP. 1982). Falo Alto, CA: Electric Power Research Institute.

\begin{abstract}
Decision-making by nuclear power plant operators was studied in the context of four secent off-normal events in order to assess the potentigl impact of various control room improvements and inrovations. Cetegories of improvements considered in the study ircluded proposed chenges in siaff organization and training, controls and displays, and computerized support systema.

The evaluation methodology involved judgments by a panel of experts regarding thie benefits of proposed improvements for apecific operator decisions. It also included the explication of a modal of operator decision-making and en analysis in terms of this model of how each improvement could help prevent or resnlve decision-making errors.

The results indicated that time stress on the crew played an appreciable role in performence failures. The report concludes that it is unrealistic to expect that further training improvernents alone can do much to address the multitude of potential situations that operators face. A combination of improvements will be necessary, integrated by 9 strong underlying operational concept that could be embodied in a computerized support aystem. The recommended approach would emphasize the detection and correction of errors when they occur, in addition to the prevention of errors.
\end{abstract}

\title{
APPLICATION
}

This report may prove interesting to those involved with current or future control room enhancement projects. The impaci of different improvements upon operator decision-making is assessed. 
Pine. S.M., Schulz, K.A., Edman, J.R., Hanson, T.G., Evens, T.G., Conzeles, W., 5mith, D. \& Seminara, J. (1982). Human engineerling quide for enhencing nuclear control rooms (Report No. EPRI NP-2411). Palo Alto, CA: Electric Power Recearch Institute.

\section{ABSTRAिโTT}

A guide documenting near-term human engineering appraaches for enhancing existing nurlear control rooms and for correcting many commonly found dieciepancies in control rooms is presented. Primary data collected during site visits to four PWR plants and the data collection procedure are reviewed; details of the guide are provided; and evaluation of the enhancement approaches vie en extensive review cycle is desaribed.

\section{AFPUICATION}

.The guide is cross-referenced to NUREG-0700 and is intended as a reference document for multidisciplinary design review teams. 
Poot, T., Price, $H_{4}$ \& Diffley, G. (1976). A guide for seleating formats and media for presenting maintenance Information (Contract No. N00600-76-C-1373). Bethesda, MD: Naval Ship Research and Covelopment Center.

\section{ABSTRACT}

The resesrch roported here developed a method for selecting formats and medie for presenting maintenance information. The work wes sponsored by the Navy Technical information Presentation Project (NTIPP), an exploratory development program beirg conducted by the David W. Taylor Naval Ship Research and Development Leboratory, Carderock, Marylend.

The Navy plans to evaluate the product of this reaearch in a shipboard setting. The evaluation will assess the feasibility of epplying the method (does the guide provide adequate guidance for selecting formets and media?) and the utility of the selection (what are the benefits of presenting information in the formets and media indicated by the selection method?).

\section{APPLICATION}

Useful information for procedure or documentation development, especially in the aree of maintenance, is presented in this report. 
Potach, L.M (1980), Analysis of licensee event report (LER) and noncompliance data related to licensee performance evaluation (Report No, EGG-SSDC-5223). Idaho Falls, ID: EG\&G Ideho, Inc.

\section{ABSTRACT}

The Nuclear Regulatory Commission (NRC) inspection Program (noncompliance data) end the Licensee Event Report (LER) Program were aralyzed to improve the effectiveness of measures of regulatory peiformance, to describe the relationships between power plent characterietics and LERs and noncompliances, and to provlde a critical analysis of the LER and NRC Inspection Prugram. In order to accomplish these objectives, computer printouts of LERs and noncomplience dato describing events occurring between November I, 1977, to Detober 30, 1978, were analyzed for 52 power plents. Recommendations are made for implementing a program for measuring regulatory performance. The possibiitity of abandoning the concept of regulatory performance and using noncompliances to stentify epecific problems that need correction is explored. A critical analysis of the LE? and NRC Inspection Programs is also incorporated in this report, including a discussion of the new INRC Resident Inspector Program.

\section{APPLICATION}

This report would be useful to anyone interested in the effectiveness of regulatory performance. 
Price, HE. Malsano, R.E, \& Van Cott, H.P. (1981). The allocation of functions in manmachine gystems: A perspective and litergture review (NUREG/CR-2623). Wachington, DC: Nuclear Regulatory Commission.

\section{ABSTRACT}

This report reviews the literature relevant to allocation of functiuns and presents a procedure for the allocation process applicable to nuclear power plant control rooms. Methods and models that have been developed to eid the allocation process are considered, followed by examples of real-world applications. The resultant hypothesis of allocations is tested egairst environmental, system, and poychological conetraints.

\section{APPLICATION}

This report frovides an overview of the various literature available which is applicable to nuclear control room procedures and the allocation of function to system process. Evaluations and installations of gutomated and computer-based aids in nuclear power plants are also reviewed. 
Price, H.E., Post, T.J., \& Kolsrud, G. (1971). Development of information megsurement techniques for quality assurance of Nayy aircraft maintenance job aids Part E: Resaarch and development effort. Part li: h-process review test forms (Contract No. N62269-70-C-0595). Warminster, PA: Na*al Air Development Commend.

\section{ABSTRACT}

The purpose of tris study was to develop peper and pencil tests to support in-process review of aviation maintenence job aids, Two typee were developed, editorial and information content. Application of the teats should result in early detection of inadequecies and corrective feedback to technical writera.

\section{APPLICATION}

This report addresses the problem of studying the feasibility and development of information measurement techniques and for preparation of tests of technical publication during in-process review. 
Pulliain, Ro, Price, H.E, Bongarra, J, Sawyer, C.R. \& Kimer, R. A, (1983). methodology for allocating nuclear power plant control functicns to human or eutomatic control (NUREG/CR-3331). Washington, DC: Nuclear Regulatory Commission

\section{ABSTRACT}

This report deseribes a general method for allocating control functions to man or machine during nuclear fower plent (NPP) design, or for evaluating their allocation in an existing design.

The recaarch examined some important characteristics of the systems design presese, and the reasits meke it clear that allocation of control functions is an intractable problem, one which increases in ceverity with the increasing complexity of systems. The method is reported in terms of specific steps which should be taken during the early stages of a new system design, and which will lead to en optimal allocation at the functional design level of detail.

The procedure described are not expected to provide an ultilisie solution to the allocatic. uf-functions problem. However, these procedures cen at least assure that allocation of control functions is considered during design in an orderly and rational way. They should substantielly advence the genersl understanding of this problem and the ability of the design community to allocate control functions to humans or autametion in complex systems.

\section{APPLICATION}

This report explores the problem of ellocating functions to humen or eutomatic control, with particular reference to nuclear power plant control rooms. 
Remoc, 5.C., et ol (1981). Methodology for eveluation of emergency response facilfties (NUREG-0814). Washington, DC: Nucleer Regulatory Commission.

\section{ABSTRACT}

This draft report was prepared largely from the criteria in NUREG-0636 by NRC siaff assigted by contractor personnel. This report is presented in dreft form for public comment and interim use. It also will be used by the staff in this form for the lnitial reviews of the Emergency Respanse Facillties designs which ore presently being aubmitted by nuclear power reactor operators. The otaff will incorporate the experience gained fron the preliminary reviews and the comments received into a final methodology document which will be used by the staff in its determination of the acceptability of ERFB proposed by nuclear power reector licensees.

This dscument is issued for comment and to provide affected licensees an early insight into the approach the steff will use in reviewing Emergency Response Facility proposels.

\section{APPLICATION}

This report is intended for use in review of Emergency Response Facility designs. 
Remsey, H.R., \& Atwood, M.E. (1979). Human factore in compuiar systeme: A review of the literature (NTIS No. AD-A075679). Springfield, VA: National Technical ifosmation Service.

\section{ABSTRACT}

Based on an extensive literature arvey, this ducument presents a decription and critical analysis of the atate of the art in the area of human factora in computer systems. This review is cuncerned both with the status of human factors research in the area of user-computer interaction and with the current state of user-computer interaction technology and prectices. The primary purpose of the review is to determine whether research and practice in this area have evolved sufficiently to support the cevelopment of a human factors guide to computer system design. It is concluded that insufficient date exist for the development of a "quentitative reference handbook" in this area, but that a "human factors design guide" - which discusses issues, alternatives, and methods in one context of the design process - is bath feasible and needed.

\section{APPLICATION}

This report provides a review of human factors in user-computer interaction tei:hnology and practices. This data may be useful to persons upgrading computer systems or anticipating integrating a new system. 
Remeay, H.R., Alwod, M.E, \& Kirshbaum, P.J (Eds). (1978). A critically annotated bibliagraphy of the literature of human factors in computer systems (Centract No. ND0014-76-C-0866). Washington, DC: Office of Naval Reseazch (NTTS No. ar. A0580B1)

\section{ABSIRACT}

This bibliography provides a very broad sirvey of literature dealing with humpi, factors in relatiun to computer systems. Refersnces selected deal with human factors aspects of interactive computers, hardware, software, and procedures.

\section{APPLICAMON}

This bibliography would be useful in any application where interaction betwesn human factors principles and computerized systems occurs. 
Rankin, W.L., Bolton, P.A, Shiktar, R., \& Sguri, L.M. (1994). Nuclaas power plant oimulators for operator licensing gad training, Part I The need for olant-roference simulatoros Part II: The uoe of plant-rsference simulatoro (NUREG/CR-3725). Washington, DC: Nuclear Regulatory Commiesion.

\begin{abstract}
Pert I of this report presente technical justificution for the us of plant-reference simuletors in the licenoing and training of nuclear power plent rperatora and exemines altematives to the use of plant-reference simulators. The technical rationale to based on resegrch on the uss of simulators in other induatries, psychological learning and testiny prineiples, expert opinion, and user opinion. "roing technical justification exists for requiring plent-reference simulatore for operatcr licensing purposes. Technicel jugtification for tive use of plent-reference simulators fol operatnr training is less wel! grounded empirically, although expert opinion is that plant-reference simulatore, when properly used, result in the most effective trainlng. Part II discusses the central considerations in using plant-referenee sirrulators for ilcenaing examination of nuclear power plent operators and for incorporating simular ors into nuclear power plant training programe. Recommendations are presented for the administration of simulator examirations in operator liceneing that reflect t!e goal of meximizing both reliability and validity in the examination proces8. A series of orgenizational tasks that promote the scceptance, uee, and effectiveness of simulator training as part of the onsite training programi is delinected.
\end{abstract}

\title{
APPLICATION
}

There reports may be utilized by operator training and licensing personnel in administering the simulator training. 
Rarkin, W.L, Duvernoy, E.G., Morgenstern, M. Ames, K.R., \& Eckenrode, R.I (1983). Near term impravements for nuclear power plant control room annunciator systems (NUREG/CR-3217). Wesington, DC: Nuclear Regulatory Commission.

\begin{abstract}
This report seis forth a basic design philosophy with its associated functianal criteria and deaign orinciples for present-day, hard-wired nuclear power plent control room annunciator systems. It also presents 8 variety of ennunciator design festures that are either necessary for ar useful to the implementation of the degign philosophy. The information contained in this report is synthesized from en extensive literature review, from inspection and analysis of control room annunciator - pstema in the nuclear industry and in related industries, and from discussions with a variety of indiviciuals who are knowledgeable ebout annunciator systeme, nuclear plant control rooms, or hoth. This Information should help licensees and license applicants in improving their hard-wired control room annunciator systems as qutlined by NUREG-0700.
\end{abstract}

\title{
APPLICATION
}

This repert is intended for dissemination of current literature which would be applicable in control room human factors engineering. This information is helpful in licensing applications and control room applications. 
Feplogle, 20. (1983). Hand torque atrength with cylindrical handles. Proceedings of the Human Factors Society - 27th Annual Meeting a12-416.

\begin{abstract}
The relationship between the diameter of a smooth cylindrical handle and the torque that can be applied by the human hand has been analyzed. An analytical model has been derived for the maximum force that-cen be developed before the hand slips on the hendle. The model has been tentatively verified by the torque measurements on 20 subjects using a series of smooth cylinders ranging from .95 to $8.89 \mathrm{~cm}$.
\end{abstract}

\title{
APPLICATION
}

The results of this study are useful to those interested in selecting handle diameter when used in a torque situation. 
Rivo ivational Laboratory (Eds). (1982). An annotated list of publications on man-machine gystems and reliability and riak analysis, Roskilde, Denmark: Author.

\section{ABSTRACT}

This bibliography presents information as to publications availeble in the manmachine area of process plants. Emphasis is placed on humen factors In conjunction with reliability and safety.

\section{APPLICATION}

This bibliogrephy is intended for use in the human factore and risk analysis associated with men-machine interfaceg, 
Roberto, K.H, \& O'Reilly, C.A., Ill. Measuring organizational communication. Journal of Applied Psychology, 59, 321-326.

\section{ABSTRACT}

Pagt resarch on organizational communication has not included systematic development of a measurement method that can be used to compare dimenejons of communication withir, and across organizations. This research reports on initial attempts to develop such instrumentation. Seven samples, with a total of over 1,200 respondents, were used to develop a 35-item questionnaire measuring 16 facets of communication.

\section{APPLICATION}

The dimensions of communicatlon (arnount of information, timeliness of information, withholding, redundancy, and gatekeeping) that are covered in the Roberts and O'Reilly questionnaire have epplicability for nuclear power plant operations as well. The categories of communication problem areas could be used in designing a survey to assess nuclear power plant communications in a single plant or to compare across several plants. 
HFE (General)

Rodgers, S.th of Eggleton, FM (Eds). (1983). Ergonomic design for people at work. Beimont, CA: Lifetima Learning.

\section{ABSTRACT}

The book gives practical approaches for the solution to many design problems it includes examples and case atudies based on real experience. Chapters include: Workplace Design, Eouipment Design, Information Transfer and Environment.

\section{APPLICATION}

People who are involved in workplace or equipment design, human factors engineering or related fields will find this book to be a practical and useful guide. 
Rogovin, M., Frampton, G.T., Jr., Comell, EK., DeYaung, R.C., Budnitz, R., \& Norty, P. (1980). Three Mile Island: A report to the commission and to the public (NUREG/CR-1250, Volume 1). Washington, DC: Nuclear Regulatory Commission

\begin{abstract}
This report presents the results of the investigation by the lew firm of Rogovin, Stern, \& Huge to review and report on the accident at Three Mile Island. The principal objectives of the inquiry were to determine what happened and why, to assess the uctions of utility and NRC personnel before and during the accident, end to identify deficiencies in the system and areas where further investigation might be warranted. This first volume contains a narrative description of the accident and a discussion of the major conclusions and recommendations.
\end{abstract}

\title{
APPLICATION
}

This work was designed to enable the NRC to fulfill its regulatory responsibilities by achieving the fullest possible understanding of the accident, both from a technical point of view and from the standpoint of how the NRC's own regulatory processes functioned. 
Rognvin, Mog \& Frampton, G.T., Jr, (1980). Three Mile Islend: A report to the commissicners and to the public (NUREG/CR-1250, Volume 2), Washington, DC: Nuclear Regulatory Commission.

\section{ABSTRACT}

This report presents the results of the investigation by the law firm of Rogovin, Stern, \& Huge to review and report on the accident at Three Mile lsland. The principal objectives of the inquiry were to determine what happened and why, to assess the actions of utility and NRC personnel before and during the accident, and to identify deficiencies in the system and areas where further investigation might be warranted.

This second volume is divided into three parts. Part I focuses on the pre-accident licensing and resulatory background. Part 2 focuses on the technical deseription of the accident. Part 3 ccntains descriptions and assessments of responses to the accident by (1) the utility, (2) the NRC and (3) State and Federal agencies; an analysis of information provided to the media during the accident; and a study prepared for the Special Inquiry group on safety management factors germane to the accident.

\section{APPLICATON}

This work was designed to enable the NRC to fulfill its regulatory responsibilities by achieving the fullest possible understanding of the accident, both from a technical point of view and from the standpoint of how the NRC's own regulatory processes functioned. 
Roscoe, B.J (1984). Nuclear power plant elarm prioritization (NPPAP) program statug repart Janusry 1,1983 to September 31, 1983 (NUREG/CR-3684). Washington, DC: Nuclear Regulatary Commisaion.

\section{ABSTRACT}

This repart describes the status of a research project directed towerd nuclear power plent alarm prioritization. Criteria for modlfied alarm activation are being developed and atudled. Also being developed are measures to regulate the alerm rate at some deslred level. The problem of elarm prioritization besed upon maintenence of criticel safety functions while mainteining complete alarm coversge of accidents is being addreased. The plant information needed to support the associated technical deveiopment areas is being compiled for a epecific plant, categorized, end entered into a camputer date bese. Nesi-term recommendations for regulatory ection on plant annunciator aystems are presented.

\section{APPLICATION}

This report discusses the upplication of a prioritization seheme for annunicato: systems and the problems encountered. This information would be useful to enginzers, operations personnel or human factors specialists designing or upgrading alarm systems. 
Rossiter, D., 2. Skolnick, S. (1980). Computer systems interface quidelines for nuclear plants. Palo Aito, CA: Electric Power Research hatitute, Nuclear Safety Analygis Center.

\section{ABSTRACT}

This report piovides guidence and general recommendatione for upgrading nuclear plent proceas computer installationa to meet NRC data system requirements. Prineipal technical, procurement, and operational considerations are developed in a programmatic fremeverk to facilitate system Improvemente. The scope of these considerations is directed coward present requirements, but also ellows for technological advances and expensicn in applications, as well as chenging regulatory requirements which may occur in the future.

\section{APPUCATICN}

These guidelines and recommendations would be of interast to aryone involved in upgrading nuclear power plant process systems, particularly computer installatione. 
Sabri, ZA (1980, April). Human factors in nucless power plant operation. Paper preaseated at the American Nucleer Society Thermal Reactor Safery Meztinc, Kroserille, TN

\begin{abstract}
An angersive effort is being devoted to developing a comprehensive human factors program oftet encompasses establishment of a data base for human error prediction using past opercisos experience in commercial nuclear power plants. Some of the main results of such घn efiort are reported, including data retrieval and classification systems which heve been developed to assist in estimation of operator error rates. Also, atatistical methods ase daveloped to relate operator error data to reactor type, age, and specific technical design features. Results reported in this paper are based on an analysis of LERE covering a six-year period for LWRs. Developments presently include a computer data menagemsit program, statistical model, and detailed error taxonomy.
\end{abstract}

\title{
APPLICATION
}

This report is interided to aid in establishing a data bese for predicting operator errors in commercial nuclear power plants. 
Salvendy, G. (Ed.). (1984). Human-computer interactlon: Proceedings of the firat USAJagan confarence on human-computer interaction. New York: Elovios.

\section{ABSTRACT}

This bock consists of 72 pepers which were presented at the USA-Jepan conference on human-computer interaction. The objective of the conference was to consolidate knowledge within the fields of human factors and computers in order to exchange information and new developmants. The topics covered ranged from conceptual and theoretical issues in human-computer interaction to speech gynthesis and recognition with computer interfaces. Pepers were presented in the following areas: taxonomiea, standardization, and eveluation of human-computer interaction; software design and use; artlficial intelligence; ergonomics; and stress, health-psychological issues and visual functions in relation to CRT digplay tasks.

\section{APPLCATION}

This book is relevant to the areas of human factors in relation to computers and productivity in real-worlo' applic ations. 
Samente, P.K., Swoboda, A.L. \& Hall, R.E. (1981), Sensitivity of risk parameters to humen erroro in reactor eafety study for a PWR (NUREG/CR-1879). Washington, DC: Nuclear Regulatory Commisaion.

\section{ABSTRACT}

Senaitivitias of the risk parameters, emergency safety system unevailabilities, accident sequence probabilities, release category probabilities and core melt probabilities were investigated for changes in the human error rates within the general mathodological fremework of the Reactor Safety Study for a Pressurized Water Reactor (PWR). Impact of individual human errors were assessed both in terms of their structural importance to core melt and reliability importance on core melt probability.

\section{APPLICATION}

A discussion of humen error and its consequences is presented. This report is of particular interest to individuals involved with risk assessment and human reliesility. 
Sawyer, CR, Pali, R.F., Van Coct, HC. \& Banks, W.W. (1982). Nuclear control room modifications and the role of trensfer of training princlples: $A$ review of issues and resaench (NOREG/CR-2828; EGG-2211). Washington, DC: Nuclear Regulatory Comarimion

\section{ABSTRACT}

This repart addressts iseves and research related to the implementation of NUREG. 0700 - Frecificelly, transfer of treining cansiderations ascociated with control roem modifications, retrofits, and general upgrades. The purpose of the effort was to identify literakure ond date which would indicate any apecific negative effecto of inatrumentation and control bsard chenges on aperator performance, especially under high stress conditions. An exheustiva search revealed that no dufinitive applied studies in this area had been carriat out. However, a review of the theoretical and human performance literature, with emphasis upon the generalizability of transfer of training studies to control rom modification scenarios, led to the following conclusions: (1) a judicious and systeme it application of human factors engineering design criteria will not degrade operator parformence in nuclear contrcl rooms; (2) the application of humen erigineering design criterie eppears to enhance operational effectivenesa, increase aystem safety, end allow cperators greater ease and efficiency in system control and information extraction; (3) close solherence to human engineering design criteris during control room retrofit creates a greater degree of accep"ance by operators and plant manegers; and (4) certain desigr changes could lead to negative transfer of training effects for operatora.

\section{APPLICATICN}

This research examines the potential impact of control room modifications and retrofits on user acceptance and performance, particularly fram the point of view of trensfer-oi-treining. 
Selieller, W.L-g I. (1983). The effict of handle shape on grip fatign' in manual lifting. Proceedinga of the Human Factore Society - 27th Annual Meeting 417-422.

\section{ABSTRACT}

This study investigated the effect which various handle shapes produced on grip fatigue. This was mesured throuah the calculation of a time to fatigue using a opectral analysis of the surface EMG of -ie grip muscles and through the determination of maximal pull forces in the upward direction. Significant differences existed between the handles in the maximum pull test, but not in the times to fatlgue.

\section{APPLICATION}

The results of this study are useful to those interesied in selecting handle shape when uaed in a pulling situration. 
Schroador, L,R. \& Fowler, D.R. Human factors englneering degign guideilines: $H$ Doveloped for use in the nuclear indusery. Richlend, WA: United Nuclear induatries end Fockwell International.

\section{AESTRACT}

This document cansists of more than 80 pageB of checklists covering the following humen engineering design considerations in a nuclear power plant control room: preliminary design, controls and displays, control/dieplay integration, panal layout, grouping of panels, integrating workatations and systems, and syatems and environment.

\section{APPLCATION}

These guidelines were developed for use in the nuclear industry for control room design reviews. 
Seeman, S.E, Colloy, R.W. \& Stratton, R.C. (1983). Optimization of the man-machine interface for LMFBRs. Nuclear Sofety, 24, 506-512.

\section{ABSTRACT}

An efiort is undarway to optimize the roles of man end machine in control of liquidmetel-sooled fast breeder reectors The work reported here describes two gyoteinst (1) MDAS, presently in Use, is a large deta base system developed for the Fast Fiux Test Facility (FFTF) as an aid to operators in determining how to proceed with maintenance and repairs on plant componente, end (2) the Procedure Prompting System is beirg developed to demonstrate a new methodology fer eutomaticaliy generating instructions to aid plant recovery in off-normal conditions Methodology for this system has been demonstrated ors a model of a small subsystem of FFTF.

\section{APPLICATION}

Persons interested in optimizirg the man-machine interface for LMFBRs may find this peper of use. 
Seidensteln, S., Willama, A.R., Goddard, C.J \& Cheney, M. (SRD. (1981). Human fectors seview of electric power dibpatch control centers (Report No. EPRI-EL. 1960, Volumes 1-6). Palo Alto, CA: Electric Power Resegrch Institute.

\section{ABSTRACT}

Human factors is a aystems-oriented incerdisciplinary specialty concerned with infituencing the design af systems, equipment, facilities, and operational environments to promote effective system operstions through emphasis on efficient and reliable operator Ferformance. Phace I of this projert evaluated a sample of 13 coniemporary electric power control centers by conducting site surveys; these ourveys included checklista, guided interviews, photography, direct physicel measurement, and technical discussions with operators, manegement, and supervisory personnel at each site.

The project evaluated the information avalable to the operator and the physical interface between the operator and power systems, as well as the operational setting in which task are performed. Guidelines for the application of human factors principles are given where applicable. Partieular attention was given to the design of the cathode ray tube (CRT) interfece, the data base, facility lighting, training, manring, and work strass. Several potential areas for further study are identified.

Subsequent phases of this project will study system operaitor information requirements and information interfaces between the operator and the gystem.

The realts of this research project are presented in EL-1960, a six-volume report entitled Human Factors Review of Electric Powrer Dispatch Control Centers. The six volumes are:
- Volume 1: Survey Results Summar.
- Volume 2: Detailed Survey Results
- Volume 3: Operator Information Needs Summary
- Volume 4: Operator Information Needs
- Volume 5: Information Management and Presentation Summary
- Volume 6: Information Management and Presentation.

\section{APPLICATION}

Thio project evaluated the information available to the aperator and the physical interface between the operator and power syctems, as well as the operational setting in which teako are performed. 
Selway, $R_{s} J_{a}, J_{5}$. (1984, April). Quality circles in action. Peper presented at the hatitute of Nuciear Power Operatione Maintenance Superintendents Workehop, Altante, GA

\begin{abstract}
Baltimore Gas \& Electric's Performance Improvement Prccess has three ccmponents: measurement, accountability, anid farticlpation. The first two components use traditional epproaches, such as performance indicators, work measurement, and operationa! audits. The third component, participation, besides using ach approaches as suggestion systems and training programs, also employe quality circles, a structure and process for involving erriployees in the improvement process of work-related problems.
\end{abstract}

\title{
APPLICATION
}

This paper could be used as a reference document for nuclear facilities designing a formal employee performance improvement plan. It presents guidelines for developing and imple nenting quality circles. 
Seminare, d (1982). Humen factors methods for assosoing and enhancing power plant maintainability (Repost No, EPRI NP-2360), Palo Alto, CA: Electric Power Research Institute.

\section{ABSTRACT}

This study - a follow-on effort to IJP-1567, a human factore review of nine power piants witin respect to maintainability - provides data-gathering tools for use by utilitles in reviews of their own plantg. These tools, which are applicable to both nuclear and fossil fuel plents, include an illustrated checklist; a structured interview; tagk anglyais formats; communications, illumination, and safety arreys; and potential accident and damage enalvges. Enhancement opportunities and strategies are discusged.

\section{APPIJCATION}

The topics covered by this report can help anyone involved in assessing control room maintainability by standardizing interview methods and organizing actual reviews. 
Seminara, J.La, Eckert, S.K., Seidenstein, S., Gonzalez, W.R, Stempeon, R.L. \& Pareone, 5.D. (1979). Human factore methods for nuclear control room dasign (Report No. EPRI NP.I118-SY). Palo Alto, CA: Electric Power Rege日rch Institute.

\section{ABSTRACT}

The final repart of this study is published in four volumes with this volume being the summary. In the study, human factors approaches were applied in the design of representative nuclear power plant control panels. First, methods for upgrading existing operational conirol penels were examined. Then, based on detailad human factors analyses of aperator information and control requirements, design of reactor, feedwater, and turbine-generator control panels were developed to improve the operator-control boerd interface, thereby reducing the potential for.operator errors.

\section{APPLICATION}

This summary report will be of interest to anyone involved in control room design or in eperator performance. The full report will be of interest to anyone deeply involved in the design of power plant control rooms. Designers of other types of control rooms, such as dispatch centers or process plants, may also benefit from the report. 
Seminara, J.L., Gonzalez, W.R. \& Parsons, 5.0. (1976). Humen factora review of nucleat power plant control room design (Report No. EPRI NP-309). Palo Alto, CA: Electric Power Research Institute.

\section{ABSTRACT}

Human factors engineering is an interdisciplinary gpecialty coneerned with influencing the design of equipment systems, facilities, and operational environments to promote safe, efficient, and reliable operator performance. The human factors aspects of five representative nuelear power plant control rooms were evaluated using such methods as a checklist-guided observation system, structured intervlews with operators and trainers, direct observations of operator behavior, task analyses and procedure evaluation, and historical Eiror analyses. The human factor aspects of design practices are illustrated, and many improvements in current practices are suggested. The study recommends that a detailed set of applicable human factors standards be develcyed to stimulate a uniform and systematic cancern for human factors in design considerations.

\section{APPLICATION}

Designers interested in applying human factors considerations to control rooms would find this report of use. 
Saminara, J.L \& Pack, R.W. (198Z). Communication needs of the nuclear power plant operator. IEEE Transactions on Power Apparatus and Systems, PAS-i01, 792-796.

\begin{abstract}
Nuclear power plant aperators and trainers were interviewed to examine human factors considerations ascociated with control room operation. One part of this review deslt with communications. Over 80 percent of the interview sample reported problems and frustrations with existing communication systems. The nature of the problems uncovered and fuiture research needs are the subjects of this paper.
\end{abstract}

\title{
APPLICATION
}

This paper analyzes the communication problems within a nuclear power plant as taken from interviews. 
Saminsra, J.L. \& Parsons, S.O. (1979). Human factors methoda for nuclear control room design. Volume 2: Human factorg survey of control room design practices (Report No. EPRI NP-1118). Palo Alto, CA: Electric Power Research Institute.

\begin{abstract}
The final seport of this study is published in four volumes with this volume devoted to a description of the human factors gurvey of control board design practicea. Special attention is given to warning aystem designs. Twenty board designers from a mix of architect-engineering and Nuclear Steam Supply Systems firms were surveyed. The atudy concludes that there is an urgent need for a human factors engineering design guide tsilored to the special demands of the utility industry. Also, there is a need for a human factors standard which utilities could use in specifying, developing, or evaluating new control room designs.
\end{abstract}

\title{
APPLICATION
}

The use of human factors in the design of power plant control rooms shown in the report cen be epplied to rperating power plants, as well as to those in the design stage. 
Seminare, J.L., Parsons, 5.O., Schmidth, W.J., Gonzalez, W.R. \& Dove, L.E (1980). Human factors review of power plant maintainability (Report No. NP-1567-5Y). Palo Alto, CA: Electric Power Research Institute.

\begin{abstract}
The human factorg aspects of five nuclear power plants and four fossil fuel plants were evaluated using such methads as a checkliat-guided observation system, structured interviews with maintenance personnel, direct obaervations of maintenance tasks, revlews of procedures, and analyses of maintenance errors or accidento by means of the "critical incident" technique. The study recommerids that a more systematic and formal approach be adopted to ensure that future power plants are "human engineered" to iive needs of maintenance personnel. Design guidelines and stendards are urgently required to guide the development of new power plants and to upgrade existing plants. Such guidelines and standards should be predicated on existing humen factors date supplemented by future research directed at solving problems unique to the power industry.
\end{abstract}

\title{
APPLCATION
}

This report highlights many of the "special" human enginearing problems encountered by maintenance personnel. it provides a realistic perspective on the influence of human engineering on equipment maintainability. It is a good source document for personnel or departments anticipating upgrading in-plant systerns/equipment or installing new devices. 
Seminara, J.L., Sejdenstein, 5., Eckert, S.K. \& Smith, D.L. (1979). Human factora methods for nuclear control room design. Valume 1: Human factors enhancement of existing nuclear control rooms (Report No. EPRI NF-1118). Palo Alto, CA: Electric Power Research Institute.

\section{ABSTRACT}

The final report of this study is published in segments. This volume of the final report deals with those measures that should be considered in upgrading existing operationel or nasr-operational control rooms from the human factors standpoint. The recommendations offered in this report assume that power generation will not be interrupted to accomplish the remedial measures advanced.

\section{APPLICATION}

This report demenstrates the use of human factors in the design of power plant control rooms. The approaches shown in the report can be applied to operating power plants, as well as to those in the design stage. 
5heckel, B. (Ed).(1978). Applied ergonomics handbook (5th ed.). Surrey, Englend: IPC.

\section{ABSTR.ACT}

Industry requires man-plus-machine to be an efficient production unit. Eryonomics can help in the design or process of a product, and with general working conditions. This book emphasizes factors that affect people in industry, and provides a summary of important European ergonomics research.

\section{APPLICATION}

People who are involved in industrial workplace or equipment design should find this a helpful guide. This book covers various areas such as displays, noise, and lighting. 
Shea, D.J., Jr. (1981, October). Analytical technigues for creating a job design basis for a nuclear power plant operating crew. Peper presented at CSNI Specialist Meeting on Operatur Training and Qualifications, Charlotte, NC.

\section{ABSTRACT}

This paper attempt 3 to give some direction to answering two questions:

1. How a:e the operational needs of a plant defined?

2. Once defined, how are the operational needs of a plant allocated to the human, to an automatic function, or to both?

The methodology involves comparing three current system analysis proce fures - Meister's determination of system requirements and functions, the suggestions of the NRC in NUREG-0659 Appencix. 2 , end a System Operabilit* Assessment Review Project currently being conduted on a FWR - and combining the besi features of each approach.

\section{APPLICATION}

The primiary thrust of this paper is to make a case for Job Design and to suggest analytical tochniques for doing it. The paper is addressed to en audience concerned with either operational plants or plants whose design is nearly complete. 
Sheehy, E.J. (1983). A nuclear sariby basis for assigning priorllies to human engineering concerns at nuclear power plants. Proceedings of the Human Fectors Society -27 th Annual Meeting, 1, 180-183.

\section{ABSTRACT}

While it is generally agreed that safety-related discrepencios should receive first priority, it is not at sll clear just wh:ei "safety-related" meens when considered in an cperational sense. This paper dascribes tha current state of evolving standard definitions for hardware-oriented safety features it discusses ho' thise definitions could be expanded to include operationally related considerations and explores some benefits wh:ch would erısue. These include (1) establishing a nuclear sefety basis which can be used in establishing priorities for re sclution of humen engineering concerns, and (2) chtaining legal recognition of operational concarns in genera! in the design and licensinb arenas.

\section{APPLICATION}

This document couid be useful to persons involved in evaluation of humen engineering problems. Discussion exists on the meaning of "sefety-related" in terms of equipment or systems. 
Sheridan, T.B. (1980, February). Human error in nuclear pewer plants. Techinolony Review, 23-33.

\section{ABSTRACT}

This report discusses the dilemma of coping with humen error. Nuclear power, commercial aviation and office operations of all I:inds are becoming more automated to circumvent the human operator. No complex syatems where human lives or large amounts of capital зre at risk can be allowed to run completely by itself; somewhere there is a human operator to control and monitor and take over in case of emergency. It also discusses human reliability versus machine reliability. Finally it suggests that the computer offers a way to help the operator.

\section{APPLICATION}

Those interested in human error and ways of reducing it will find this paper of use. 
HFE (General)

Sheridan, T.B. \& Jahannsen, G. (Eds). (1976). Monitoring behavior and superviscry control. New York: Plenum Fress.

\section{ABSTRACT}

This book includes all papers presented at the Internation: Symposium on Monitoring Behavior and Supervisory Control of March 1976. The pa; ars are organized into three sections: man-vehicle controh, general models, and process control. Following these three sections of papers are brief reports of four workehops which were held in conjunction with the symposium.

\section{APPLICATION}

This book is a useful reference for those interested in defining the problems in manmachine situations, and toward meeting engineering needs. 
Shives, T.R. \& Willard, W.A. (Eds.).(1991, April). Innovation for maintenance technology improvements: Proceedings of the 33rd meeting of the mechanical fallures prevention group. Gaithersburg, MD: National Bureau of Standards,

\section{ABSTRACT}

These proceedings consist of a group of 34 submitted entries ( 32 papers and 2 abstracts) from the 33rd meeting of the Mechanical Failres Prevention Group which was held at the National Bureau of Standards, Gaithershurg, Maryland, April 21-23, 1981. The subject of the symposium was maintenance technology improvement through innovation. Areas of special emphasis included maintenance concepts, maintenance analysis systems, improved maintenance piucesses, innovative maintenance diagnostics and maintenance indicators, and technology improvements for power plant applications.

\section{APPLICATION}

These papers would be of use to anyone interested in maintenance technology and prevention of mechanical failures in particular. 
Siegel, A.I., Bartter, W.D. \& Kopstein, F.F. (1982). Job analysis of maintenance mechanic position for the nuclear power plant maintenance personnel reliability modal (NUREG/CR-2670). Washington, DC: Nuclear Regulatory Commission.

\begin{abstract}
An analysis was performed of the job of maintenence mechenics in nuclear power plants in order to provide a part of the information required for modeling nuclear plant maintenance activities. It is believed that such a model would provide aubstantial insights into the various human, equipment, and environmental factors thet are likely to affect reliability of maintenance personnel, and thereby suggest and allow evaluation of standards, design changes or other modifications to improve reliability and minimize public risk.

The work yielded a diversity of information relative to the job of the maintenance mechanic in nuclear power plants. The information obtained will be used to develop the logic and content of a model for quantitatively assessing the actir:ies of maintenance personnel, especially from the paint of view of public safety.
\end{abstract}

\title{
APPLICATION
}

This paper provides the necrssary information for those interested in a maintenance pursonnel reliability model. Many implications are given in the executive summary. 
Siegel, A.J., Bartter, W.D., Wolf, J. J., Knee, H.E \& Haak, P.M. (1983). Front-end analysib for the nuclear power plant maintenance personnel reliabillty model (NUREG/CR2669). Washington, DC: Nuclear Regulatory Commission.

\section{ABSTRACT}

The front-end enalysis performed for the nuclear power plant maintenence personnel seliability modeling program consisted of three primary takks which eie addressed within this report. The first of these was a front-end user survey which investigated the need for and potential content of a structured methodology for nuclear power plant maintenance. The second task was a literature review of existing human behavioral methodologies and an ascessment of their applicability for this program. The third task was the development of a comprehensive program plan for the maintenance reliability model.

Results of these tasks indicated that a computerized model would be very useful and that the type of methodology to be developed should be of the simulation type. This report also provides a 35 -month program plan for its development.

\section{APPLICATION}

A description of a front-end analysis for a maintenance personnel reliability inodeling programi is contained in this report. This information plus the 35-month program plan for the analysis development would be useful to persons interested or involved in maintenance front-end analysis. 
Siegel, A.L, Federnian, P.J. \& Butkett, J.R. (1974). Increasing and evaluating the readability of Air Force written materials (Report No. AFHRL-TR-74-28). Lowry AFE, CO: Air Force Human Resource Laboratory. (NTIS No. AD 786-820)

\section{ABSTRACT}

This raport describes how to apply techniques that have been used in measuring the readability/comprehensibility and reading level of textual materials. Instructions are provided in a step-by-step fashion for determining the reading level of written material and for presenting subject matter material through methods rather then prose. The report alsn explains the procedures in the appendices for various readability techivique analyses.

\section{APPLICATION}

This manual is intended to serve as a sou. ze document for use by Air Force training and development personnel, as well as others who prepare reading material for the Air Force. The principles outlined could be useful to individuals involved with preparation of written materials. 
Pracedures

Siegel, A.I., Lambert, J.V. \& Burkett, J.R. (1974). Techniques for making written material more readable/comprehensible (Report No. AFHRL-TR-74-47). LowTy AFB, CO: Air Force Humen Resource Laboratory. (NTIS No. AD 786 849)

\section{ABSTRACT}

This technical memorandum presents an outline if how to apply poycholinguistic and iritellective concepts to enhance the readability and comprehensibility of written materials. Guidelines for making the reader's task easier are provided, and some readability measurement procedures are also discussed.

\section{APPLICATION}

This material ma; be useful to persons involved in procedures upgrades, procedure development or manual preparation. 
Smidt, D. (1980, November). Human error: An essential problem of nuclear power plants. Paper preserited at the 7th Annual PNS Colloquium, Karlgruhe, F.R. Germany.

\section{ABSTRACT}

The author defines the part played by man in the nuclear power plant. The discussion of tactical errors and their avoidance is followed by a report on the actual state of plest technology and possible improvements. Subsequently a study of the strategic errors stemming from the interaction between plant and man, personnel selection, and education is made.

\section{APPLICATION}

If the interaction between man and machine is designed with the physiological strengths and weaknesses of man taken into account, human errors will not be essential problems in nuclear power plants. 
Speaker, D.M., Thompson, S.R., \& Luckes, W.J., Jr. (1982). Identification and analysis of humen errors underlying pump and valve related events reparted by nuclear power plant licensees (NUREG/CR-2417). Washington, DC: Nuclear Regulatory Commission.

\section{ABSTRACT}

This report provides a useful arid adaptable data base of human error associated with the cperation, testing, and maintenance of reactor safety system pumps and valves in licensed nuclear pewer plants. To produce this data base, a practical and workable methodology was developed and implemented on more than 3,000 Licensee Event Reports (LERs) which resulted in a human error data base six times larger than indicated by the LERs themselves. This data base is intended to provide a realistic assessment of the appropriate human error populations required in NUREG/CR-1880.

\section{APPLICATION}

This feport provides a data base which is associated with the operation, testing, maintenance reliability, and valves in nuclear reactor safety system pumps. 
Staff. (1969, May). Annunciator Review. Inst' ments \& Control Sygterns, 19.

\section{ABSTRACT}

This article provides a synopsis of various annunciatore on the market today. A brief overview of ennunciator functions and applications is provided. The review examines 39 manufacturers and the applications in which various combinations if interface may be used.

\section{APPUEATION}

The review is intended for use in situations where monituring of a condition is necessary. 
Stewart, C. (1981). The probability of human error in salected nuclear maintenance tesks (Report No. EEC-5SDC-5580), Washington, DC: Nuclear Regulatory Commission.

\section{ABSTRACT}

This is an informal, preliminary report of a study that used a refined survey technique to collect human error data on nuclear reactor maintenance. The objectives of the study were to test a technique for collecting sensitive human error date in cuch a way that it can be used for statistical calculations of probability. This type of data is useful in engineering design, human engineering, and fault tree analysis during research and development and during assessment of operational systems. Although results of this survey are preliminary, the response rate and quality of returns are sufficiently high to encourage further development and use of the technique.

\section{APPLICATION}

The survey technique reported here is especially applicable to the collection of human error data in process control and mainterialice operations. Such data can be difficult to acquire in an objective, systematic, and complete fashion, so that they are useful for statistical data processing. This technique apparently overcomes those obstacles. 
Stewart, C. (1981). Reactor operator adaptation to design chenge (Report No. EGG-5SD55644). Washington, DC: Nuclear Regulatory Commission.

\section{ABSTRACT}

This report reviews the learning theory concepts of stimulus-response and negative transfer and describes how they may be used to explain potential reactor operator performance problems following control room design medification. Reactor operator adaptation as a potential problem was identified as the tempo increased for control room review and modification during 1979-1980, as a respense to the Three Mile Island incident.

\section{APPLCATION}

This report will be of use to anyone concerned with operator performancr/trainitig after control room design review and inodification. 
Stewart, C. (1982). Hiuman reliability and fault tree analysis. Proceedings of the Human Factors Society - 26tr. Annual Meetinn, 664-667.

\section{ABSTRACT}

A methad was developed to collect data on human reliability as an adjunct to fault tree analysis. The need for these data, the method used for data collection, and the utility of quaritified data for design a:mport are described. Recommendations a: $r$ made for research to raise the sample size and validate the estimates.

\section{APPLICATION}

This survey technique is feasible for use in research and development, and in system evaluation. It can be used to identify problems and place them into perspective. It can also be used to compare systems (different systems or the same systems, before and after modification). 
Maintenance \& Reliability

Stilwell, W.G., Seaver, D.A. \& Schwartz, J.P. (1982). Expert astimatien of human error probebilities in nuclear power plant. operations: A review of probability assessment and scaling (NUREG/CR-2255). Washington, DC: Nuclear Regulatory Commission.

\begin{abstract}
This report reviews probability assessment and psychological scaling techniques that could bo used to estimate human error probabilities ( $H E P_{B}$ ) in nuclear power plant operations. The techniques rely on expe:t opinion and can be used to estimate HEPs where data do not exist or are inadequate. These techniques have been used in vurious other contexts and have been shown to produce reasonably accurate nrobabilities. Some problems do exist, and limitations are discussed. Additional topics covered include methods for combining estimates from multiple experts, the effests of training on prciability estimates, and some ideas on structuring the relationship between performance shaping factors and HEPs. Preliminary recommendations are provided along with cautions rogarding the costs of implementing the recommendations Additionel research is required jefore definitive recommendaiions can be made.
\end{abstract}

\title{
APFLICATION
}

This information would be useful to persons interested in predicting human error probability or human reliability. The report discusses techniques for probability assessments and psychological scaling. 
CRTs, VDTs, SPDS

Validation \& Verification

Straker, E.A. (1981). Verification and validation for safety-parameter display systems

(Report Na. EPRI-NSAC-39). Palo Alto, CA: Electric Power Research Institute.

\section{ABSTRACT}

This report defines a level of verification and validation which is appropriate for a Safoty Parameter Display System (SPDS). Specific verifieation and validation activities are defined. The expected resuits of each activity are identified by indicating typical contents of documents that would be produced.

\section{APPLICATION}

This report provides information which can be used by utilities or vendors to develop verification and validation procedures, plans, and activities for SPDS application. 
Swain, A.D. (1980). Human factors in nuclear power plant operations (Contract No. AC04-76DPDD789). Albuquerque, NM: Sandia National Laboratory.

\section{ABSTRACT}

This report deseribes some of the human factors problems in nuclear power plants and the technology that can be employed to reduce those problems. Many of the changes to improve the human fectors in existing plants are inexpensive, and the expected gain in human reliability is substantial. The human factors technology is well-established and there are practitioners in most countries that have nuclogr power plants.

\section{APPLICATION}

This report demanstrates the use of humen factors technclogy to reduce reliability problems in the design of nuclear power plants. 
Swain, A.D. \& Guttman, H.E. (1980). Handbook of human reliability analygis with emphesis on nuclear power plant applications (NUREG/CR-1278), Washington, DC: Nuclear Regulatory Commission.

\section{ABSTRACT}

The puspose of this handbook is to aid fualified persons in evaluating the effects of human errar on the availability of engineered safety features and systems in nuclear power plants. The handbook expands the human error analysis presented in WASH-1400 and includes principles of human behavior and ergonomics, analytical procedures, mathematical models, and human error probabilities derived from related performance measures and experience.

\section{APPLICATION}

The derived probabilities should be adequate to determine the relative merits of different configurations of equipment, procedures, and operating practices within a plant and for gross comparisons among plants. 
Taylor, D.F., \& Voss, T.J. (1981). A pilot evaluation of three alternative formats for emergency control room procedures. Transactions of the American Nuclear Society, 43. 235-236.

\section{ABSTRACT}

The format of control room procedures is nne aspect of procedure utility that can affect the capabilicy of operators to diagnose and manage abnormal transients. Procedure utility refers to the usability and acceptability of the procedures to the operator. This paper describes an effort to define operationally the utility of procedure formats and to establish the relative utility of several proposed formats.

\section{APPLICATION}

Information is presented about performance differences using different formats. This data could be of interest to individuals developing documentation such as procedures. 
Tiesenhausen, G.V. (1982). An approach toward function allocation between humans and machines in space station activities (NASA Report No. TM-82510). Weshington, DC: National Aeronautics and Space Administration.

\section{ABSTRACT}

Present NASA and contractor studies are evolving toward the definition o: a future man:ed permanent space station. This report attempts to provide certain basic guidelines and data to assist in the allocation of functions between humans and automated systems and for human/machine participation. The report describes the significant human ccpabilities and limitations and provides criteria and guidelines for various levels of automation and human participation. An appendix contains a collection of human factors data.

\section{APPLICATION}

This report may be helpful to engineers and other personnel making decisions concerning the allocation of tasks to humans or machines. 
Tillitt, D.N., Petersen, R.J., \& Smith, R.L (1982). Performance and design reguirements for a graphics display research facility (NUREG/CR-2711). Washington, DC: Nuclear Regulatory Commission.

\section{ABSTRACT}

Performance and design requirements for a Graphics Display Research Facility (GDRF) are presented. The GDRF is an evolutionary, computer-based, hum_n-engineering experimentation center that is specifically designed to address long-term research issues associated with automation, human performance, and risk in the operation of nuclear focilities. It is expected that the CDRF will meet future human-engineering research neec ' in a more timely and cost-effective manner then is possible under current condicions.

This report discusses the requirements, specifications, and implementation considerations for the facility; the necessary hardware, software, and personnel copabilities; and the potential costs of construction and operation for various levels of research activity.

\section{APPUCATION}

Research capabilities provided by the GDRF will directly support the licensing and regulation of nuclear facilities within the U.S. The ultimate goal of this research is to support regulatory directives for minimizing the risk of human error in the aperation of nuclear facilities. 
HFE (Ceneral)

Tcpmillet, D.A., Burgy, D.C., Roth, D.R., Doyle, P.A \& Espey, J.J., Jr. (1981). Survey and enalysis of communcietions problems in nuclear power plants (Report No. EPRI NP-2035). Palo Alto, CA: Electric Power Research Institute.

\begin{abstract}
This report presents the results of a Technical Planning Study performed to investigate communications problems in nuclear power plants. Four operating power plants were surveyed by a research team comprised of human factors, operations, and engineering personnel. Specific problems identified were that (1) existing systems cannot hendle high communications demand due to outmoded or incompatible equipment, (2) communications systems lack centralization, (3) high signal density and multiple messages result in confusion and failure to process signals, (4) noise levels in both the control room and other plant areas reduce speech intelligibility, and (5) communications procedures are not well developed and are not utilized to their best advantage.
\end{abstract}

\title{
APPLICATION
}

Even though the primary purpose of this study is to furnish a point of departure for the conduct of future research, the specifjcity and nature of the findings should be of interest to design organizations and plant managers. 
Topmiller, D.A., Ecke1, J.S., \& Kozinsky, E.J. (1982). Humen relisbility dato Gank for nuclear power plent operation. Volume it A review of existing human reliability cata banks (NUREG/CR-2744). Wasinington, DC: Nuclear Regulatory Commission.

\section{ABSTRACT}

This report describes a survay and comparative analysis of previous and current atteripls to quantify and predict human operator and maintainer performance as a function of design, training, procedural, or situational factore. An assessment was made of these methods and techniques as to their potential applicability to PRA and as a supplement to the data and procedures in NUREG/CR-1278.

\section{APPLICATION}

This report provides information needed to implement a data bank for human reliability procedures. The review of previously established data banks ensures the reader hes various options to choose from. 


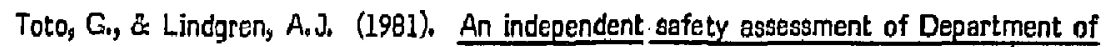
Energy nuclear reactor facilities procedures, operations and maintenance (Report No. DOE/US-008). Washingtor, DC: Department of Energy.

\section{ABSTRACT}

The 1979 accident at the Three Mile Island commercial nuclear power plant led to s number of studies of nuclear reactors, in both the public and private sectors. One of these is that of the Department of Energy's (DOE) Nuclear Facilities Personnel Qualification and Training (NFPQT) Committee, which has outlined tasks for assessment of 13 reactors owned by DOE and operated by contractors. This report cnvers one of the tasks, the assessment of procedures, operations, and maintenance at the COE reactor facilities, based on a review of actual documents used at the reactor sites.

\section{APPLICATION}

A reasoneble profile of procedure characteristics is derived from a comprehensive list of documents in use at the DOE reactor sites. Characteristics of a well-operated plant are prcduced from a review of industry siandards end guidance. 
Turner, J.A. \& Karesek, R.A, Jr. (19B3). Software ergonomics: Effects of computer application design parameters on operator task performance and health. Ergonomics, 27, 663-690.

\section{ABSTRACT}

Evidence is reviewed that the operating characteristics of computer application aystems, in addition to physicel characterio ics of display units (CRTs), are the cause of many observed effects on operator health and task effectiveness. These effects are hypothesized to occur through changes in task structure, and the man-machine redivision of labor that results when computer application systems are introduced into the work setting. First, the essociation between task dimensions and models of operator performance effectiveness and well-being are reviewed. Second, application system design parameters that affect task structure are identified. Then, empirical evidence supporting this three-part causal linkage - application system parameters to task characteristics to operator effectiveness and health - is presented. The findings suggest that by improving djalogue quality, taking advantage of two-way communication to reduce uncertainty, using smaller and less integrated systems and matching system performance to operator needs, a job can be created that is likely to improve both operator well-being and effectiveness.

\section{APPUCATION}

Since display units (CRTs) are becoming a part of many jobs today, this paper is a useful guide to some of their observed effects on operator health and task effectiveness. 
1J.S.A. Standards Institute. (1960). Method for measurement of monosyllabic word intellipibility (USAS 53.2-1960). New York: Author.

\section{ABSTRACT}

This report is intended to describe the procedures to be followed in conducting inteliigibility tests which employ monosyllabic word lists. The tegt is intended to provide a yardstick or baseline for the measurement of identification of spoken words over communication systems.

\section{APPIICATTON}

This report provides information on standards associated with intelligiblity of communications over various amplification systems. This test can be used to check speech intelligibility over various communication devices. 
HFE (General)

Van Cott, H.P., \& Kinkade, R.G. (Eds). (1972). Human engineering guide to equipment design (rev. ed.). Washington, DC: U.S. Gevernment Printing Office.

\section{ABSTRACT}

The primary purpose of this boak is to provide a guide in human engineering which the designer can use in the same inanner as handbooks in other areas to assist in solving design problems as they arise. It provides in a single volume authoritative data, principles, design fractices, and a comprehensive bibliography.

\section{APPLICATION}

This guide will be a useful reference that will assist individuals in identifying and resolving HFE problems, and in determining what is important at various design stages. 
Vesely, W.E., Davis, T.C., \& Saltos, N. (1983). Measures of the risk impacts of testing and maintenance activities (NUREG/CR-3541). Woohington, DC: Nuclear Regulatory Commission.

\section{ABSTRACT}

This report is a companion to the previous report, Measures of Pisk Importance and Their Applications: NUREG/CR-3235. This report focuses on quantifying the importance of online tests, maintenances, and repairs in controlling the risk. The importance measures which are defined are applied to evaluate the corrective and preventative benefits of onlire testing, maintenance, and repair. The corrective and preventative benefits are measured in terms of the impacts in risk which result. The corrective value of a repair or unscheduled maintenance action is termed $t$ - restoration worth of the action and is defined to be the reduction in risk which results from restoring a failed component or system. The preventative value of a test or maintenance action is termed the expected worth of the action and is defined to be the expected risk reduction from performing the action. There is a great deal of information obtainable from these kinds of measures which can be simply calculated in any PRA and enhance the usefulness of the PRA. If there is a general message from this work regarding risk assurance programs and inspection programs it is on the usefulness of risk analysis techniques in 'hese programs. To be most effective with regard to risk control, inspection programs ani risk assurance programs directed at testing and maintenarce should be guided by the risk impects of the test or maintenance.

\section{APPLICATION}

This report discusses preventative and corrective maintenance. Testing (including online) and repair are also covered. These factors are reviewed in relation to risk analysis. This material would be of interest to individuals involved with risk as.'irance programs and risk control inspection programs. 
van Herrmann, J.L. (19e3). Methods for review and evalustion of emergency procedure guidelines. Volume I: Methodologies (NUREG/CR-3177). Washington, DC: Nuclear Regulatory Commission.

von Herrmann, J.L., Brinsfield, W.A., \& Brown, R.G. (1983). Methods for review and evaluation of emergency procedire quidelines. Volume II: Application to Westinghouse plants (NUREG/CR-3177, EGCi-2243). Washington, DC: Nuclear Regulatr:y Commission.

Brinsfield, W.A., Burns, E.T., McClymont, A.S., Mays, S.E., \& von Hersmann, J.L. (1983). Methods for review and evaluaiion of emergency procedure guiaelines. Volume Ili: Application to General Electric plants (NUREG/CR-3177, EGG-2243). Washington, DC: Nuclear Regulatory Commission.

\section{ABSTRACT}

Systematic methods for reviewing and evaluating emergency procedure guidelines are presented. The de, viencies of existing "event-oriented" emergency procedures are discussed and the industry efforts to produce improved guidelines in the aftermath of Three Mile island (TMi) are summarized. It is concluded that the function- or systernoriented approaches which have evolved since TMI have, in theory, the potential to produce effective guidelines. Methods for systematically examining potentiol accident sequences issing "operator action event trees" are developed in this first volume which can help ensure that functiunal or symptomatic guidance can, in reality, lead to unambiguous and effective diagnosis and response regardless of the specific failure events.

In Volumes II and I.I, th : methodology from Volume I was anplied to Westinyhouse and General Electric plants respectively. Information for these two cases are detailed vithin the respective vol' mes.

\section{APPLICATION}

This information is usefu! to organizations upgrading procedures or developing symptom-based procedures. Discussion is provided on the "symptoms" approach. Two volumes specifically address Westingheuse and General Electric plants. 
Vosa, T.J. (1983). Lessons learned from a control room improvement project. Transactions of the American Nuclear Society, 44, 171.

\section{ABSTRACT}

The purpose of this project was to resolve problems identified by the U.S. Nuclear Regulatory Commission in a prelicensing audit. The major control room impravements involveó: relocating 200 controls or displays; rearranging, color coding, and engraving 1100 ennunciators; rewriting and engraving almost 5000 labels; applying demarcation and summery labeling; and improving lighting. Numerous other chanọes were made.

\section{APPLICATION}

Persons interested in a control room improvement project may find this brief papes of use. 
Voss, T.J., Tolley, W.T., \& Baker, C.C. (1983). Interprating guidelines for nuclear power plant control rooms. Proceedings of the Humen Facicora Society - 27th Annual Meeting, 1, 20-22.

\begin{abstract}
If human factors guidelines are not carefully interpreted and applied, control room projects can be degraded. Evaluation guidelines can be misleading when used for designing control room improvements. Guidelines identify what may be adequate, but not the best solutions. The quality of an improvement project depends upon finding the best feasible solution for each problem. Therefore, reliance should be placed not merely on NUREG guidance, but rathe: upon the larger body of human factors literature.
\end{abstract}

\title{
APPLICATION
}

The guicelines for control room design review are helpful up to a point at which looking at other huinan factors literature will prove invaluable. 
Wait, H.J., \& Manning, M.W. (1980). Design concepts for independent central alarm station and secondary olarm station intrusion detection systems (NUREG/CR-1468). Washington, DC: Nuclear Regulatory Commission.

\section{ABSTRACT}

Fixed-site nuclear fecilities are required to have a continuousiy menned Central Alarm Station (CAS) and Secondery Alarm Station (SAS). All security alarms are required to annunciate at each alarm station such that a oingle act cannot remove the capability of callipn for assistance. This report reviews various types of intrusion detectors, signal tranamission method's and receiver units relative to establishing the required intrusion alarm system's independence and redundancy.

\section{APPLICATION}

This planning document is a reference guide for establishing independent intrusion alarm anninciator systems for the Central Alarm Station (CAS) and Secondary Alarm Station (SAS) at fixed-site nuclear facilities. 
Women

Ward, 3.5. (1984). Women at work - ergonomic consideration8. Emonomics 27, 475-480.

\section{ABSTRACT}

This peper explores the ergonomic implicatians for women at work of the provisions contained within the Health and Safety at Work Act of 1974, with particular reference to the design and maintenence of equipment, lifting and carrying tasks, training and supervision, access to the workplece and the working environment.

\section{APPLICATION}

Given the increasing number of women in the work force, and their differences in body size, miuscle strength and visual and auditory acuity from men, this article gives a general background for ergonomic considerations for women at work. 
Webb Assacietes (Eds). (1978). Anthropometric source book. Volume l: Anthropometry for designers. Volume II: A hendbook of anthropometric data. Volume II: Annonated bibliography of anthrapometry (NASA Reference Publication 1024). Washington, DC: National Aeronautics and Space Administration.

\section{ABSTRACT}

The anthropometric source book is designed to provide NASA, NASA contrectors, the aeros ace industry, Government agencies, and a wide variety of industrial users in the civilian sector with a comprehensive, up-to-date tabulation of enthropometric data. Specifically, it is tailored to meet the needs of engineers engaged in the design of equipment, habitability areas, workspace layouts, life-support hardware, and clothing for the NASA Space Shuttle/Spacelab program. The intent is to provide the designer not only with dimensional data but with underlying anthropometric concepts and their application to design.

Volume $\mathrm{l}$ is a nine-chapter treatment covering all basic areas of anthropometry and its application to the design of clothing, equipment and workspaces.

Volume II summarizes the results from anthropometric suverys of 61 military and civilian populatiuns of both sexes from the United States, Eutope, and Asia.

Volume III lists 236 annotated references related to the field of anthropometry.

\section{APPLICATION}

One of the most comprehensive collections of anthropometric data is contained within this three-volume series. These materials are useful to the designer or human facturs specialist interested in body dimensions. In addition, Volume 11 contains data on European and Asian populations. 
Weiss, C. (1983). Use of panel enhancements as operator uids in nuclear pr wer plant control rooms. Proteedings of the Human Factors Society - 27th Annual Meeting, 1 , 89-92.

\section{ABSTRACT}

Topical panel enhancement techniques were designed and implemented for one nuclear power plent control room. Panel enhancements designed and implemented effectively can be good aperator aids for the searching and identifying of plant instrumentation, and in the processing of information.

\section{APPLICATION}

This paper discusses the purpose of providir.j operator aids through topical panel enhancements, and the constraints and methodology used in designing and is plementing thiee panel enhancemnt techniques. 
HFE (General)

Woodson, W.E. (1981). Human factors design hanobook. New York: McGraw-Hill.

\section{ABSTRACT}

This hendbook is designed to provide a general reference to key Luman factors questions and human-product interface design suggestions in a form that engineers and designers can utilize with a minimum of searching or studying.

\section{APPLICATION}

This can be used as a handbook reference for data and guidelines on human factors engineering. The information is applications-oriented rather than theoretical or tutorial. 
Wright, P. (1977). Presenting technical information: A survey of research findings Instructional Science, 6, 93-134.

\section{ABSTRACT}

This peper reviews research investigations into varinus aspects of the presentation of technical jaformation. It considers the objectives of different readers who ray be consulting the information as a reference work or who may need to assimilate the information in its entirety. Ways of using headings, summaries and questions to achieve these differing objectives are discussed. The review also considers the usefulness of alternatives to prose, such as flowcharts, tabulation schemes and graphic presentations. it is concluded that although there is no single "best" presentation format, and although the research literature is in many places incomplete, nevertheless there are a number of studies demonstrating the advantages of particular presentation formats in specific circumstances. The results of these studies need to be given due weighting where decisions are taken about the appropriate way of presenting any technical information.

\section{APPLICATION}

This article provides excellent information on different methods for presenting information to the reader. Major topics include: a) the needs of different readers, $b$ ) the value of headings, c) use of flowcharts, tables and graphs, d) use of illustration, e) writing prose so that it can be understood, and f) presenting inforination so that it can be remembered. This is an exellect article for anyone contemplating writing proceJures, instructions or monuals. 
Wright, P. (1981, September). "The instructions clis trly state ... " Can't people read? Áplied Ergonomics, 131-141.

\section{ABSTRACT}

Understanding and complying with the instructions that accompany consumer products is not elways easy, and indeed people may ignore the instructions entirely. Designing adequate ingtructions is a complex task. The basic requirements for good insiructions can be specified, but the problem is cne of developing adequate desigin procedures to meet them. Such procedures will involve coordinating the skills of experts in verbal and graphic communication, es well as thase of experts familiar with the research literature and with techniques of empirical evaluation. The consequences of poor instructions can be serious. Moreover, changes in the legal nction a; product liability may encourage manufacturers to se examine how their instruetions are prepared.

\section{APPLICATION}

This paper will be of use to these who must write clear concise instructions, whether for consumer products or industrial machiriery. 
SECTION 3.0

SUPPLEMENTAL BIELIGGRAPYYY 
Al'ison, C.E. (19Ei, April). Job and task analysis: $A$ view from the inside. Paper presented at the Symposium on Training of Nuclear Facility Personnel, Gatlinburg, TN

Altman, J.W., Marchese, A.C., \& Marchiandı, B.W. '1961). Guide to design of mechanical equipment for maintenance ability (f SD Technical Report No. 61-381). WrightPatterson AFB, OH: Air Fcrce Human Resources Laboratory. (NTIS AO-2 9332)

American National 5tandards Institute. (1973). Nuclear safety criteria for the design of slationary pressurized water reactor plants (ANSI N18.2-1973). LaGrange Park. IL: Author.

American National Standards Institute. (1975). Revision and addendum to nuclear safety criteria for the desio of stationary pressurized water reactor plants ANSI N18.2I973 (ANSI N18.2f 1973). LaGrange Park, ILt Author.

American National Standards institute. (1977). Draft American national standard IEEE trial-use star iard criteria for safety systems of nuclear power generating stations (ANII/IEEE 5tJ 603). LaGranoe Park, IL: Author.

Americ an National Star Jards Institute. (1978). Design basis criteria for safety systems in nuclear power generat ing stations (ANSI/ANS 4,1). LaGrange Park, IL: Author.

Banks, W.W., Blackman, H.S., Gertman, D.I., \& Petersen, R.J. (1982). A multimethods approach to safe ty parameter display evaluation (NUFEG/CR-2300). Idaho Falls, iD: EGRG Idaho, Inc.

Ben-Yaacov, G., \& Good, E.M. (Eds.). (1980). Human factors considerations in the design of man-machine interface for power plant procesj computers. Omaha, NE: Gibbs \& Hill, Inc.

Blanchard, B.S., \& Lowery, F.E. (1969). Mointainability: Principles and practices. New York. MCGraw-Hill.

Enckhold, G., Jr, \&x Roth, D.R. (197日). Performance measurement sustern for training vimulators !nterim report on EPR' Project 769, NP-783). Palo Alto, CA: Electric Power Research Institute.

Booch, M., Brodoky, R.S., \& Frenkhouser, W.L. (1981, February). Sefety overview and manegement function. Albuquerque, NM: Sondia National Leboratory. 
Bocthardt, MuJ, \& Bounas, D.A. (1981, April). Developing control room operator procedures. Faper presented at the Symposium on Training of Nuclear Facility Persannel, Gat)intuirg, TN.

Brynda, W.J., Lobner, P.R., Powell, R.W., \& Straker, E.A. (1978). Design quide for categcry II reactors, light and heauv water-cooled reactors (NTIS BNL-50B31-II, UC-80). Uptrn, NY: Brookhaven National Laboratory.

Center '́or Occupational Research and Development. (198C). Resource hanobook for power plant training programs (Report No. EPRI CS-1432). Palo Alto, CA: Electric Power Research Inst itute.

Cote of federal regulations, Title 10. Chapter 1: Energy, part 55. Operator's Licenses, Washington, UC: U.S. Government Printing Office.

Department of Defense. (1966). Maintainability prograrni requirements (for systems and equipinent) (MIL-STD-470). Washington, DC: Author.

Designing for man's advances in control room operations. (1982, July/August). EPRI Journal, 6-13.

The Emergency Oparating Procedures Implementation Assistance (EOPIA) Review Group. (1983). Emergency operating fi zcedures generation package qui teline (INPO 83-

007). At lenta, GA: Institute of Nuclear Power Operations

Falley, J.D., \& Altman, J.W. (1956). Guide to design of electronic eguipment for maintainability (WADC-TR-56-218). Wright-Patterson AFB, $\mathrm{OH}$ : Air Foree Human Resuurces Laboratory. (NT15 AD-101-729)

General Physiç Durporation. (1978). Performance measuremer: system for training simulators (lnterim Report EPR! NP-783). Palo Alto, CA: Electric Power Research institute.

Gordon, J.F. (1981, March). Some ergonomic considerations of visual display units. Melbourne, Australia: Aeronautical Research Leboratories.

Fial, J.O., Ohra, G., \& Netlend, K. (1978, July). Design of pictures and use of colors and cymbols for a CRT-baced supervision system. Paper presented at the Syinposium on Water Reactor Fuel Performance, Leon, Norway. 
Institute of Electrical and Electronics Engineers Working Group 5.5. (1981, July). Proposed draft: Recommended practice for the use of color coding in nucleas yower plant panels, controls, and displays. New York: Institute of Electrical and Electronics Engineers.

Jahnsan, R.C., Thomas, D.L., \& Martin, D.J. (1977, June). User acceptance and usability of the C-141 Job Cuide Technical Order System (Technical Report AFHRL-TR-77. 31). Wright-Pasterson AFB, Ori: Air Force Human Resaurces Laboratory.

Joos, D.W., Sebti, Z.A., \& Hiusseiny, A.A. (1979). Analysis of grose ertor rates in operation of commercial nuclear power stations. Nuclear Engineering and Design, $\underline{52}$.

Kozinsky, E.J. (1981, October). Human factors reseauch using the EPRI performance measurement system. Paper presented at the CSNI Specialist Meeting on Operator Training and Qualifications. Charlotte, NC.

Luckas, W.J., Jr., Lehieri, V., \& HEll, R.E. (1982, May). Initial quantifications of human error associated with specific instrumentation and contral system components in Iicensed nuclear power plants. Upton, NY: Brookhaven National Laboratory.

Michelson, C., \& Hemes, C.J. (1981). New trends in the evaluation and implementaiton of the safety-related aperating experience associated with NRC-licensed reactors. Nucle ar Safety, 22, 11 .

Nuciear Facilities Personnel Qualifications and Training Committee. (1981). A safety assessment of Department of Energy ruclear reactorg. Washington, DC: Department af Energy.

Nuclear Regulatory rommission, (1981). Behavioral reliability pragram for the nuclear industry (NUREG/CR-2076). Washington, DC: Author.

Nuclear Regulatory Commission. (1981). Standerds for psychological assessment of nuclear facility personnel (NUREG/CR-2075). Washington, DC: Author.

Pergencky, J.J. (1981, Detober). The U.S. NRC Division of Human Fenters safety percpective on operator training and qualifications. Paper presented at the CSN! Specialist Meeting on Operator Training and Qualifications, Charlotte, NC.

Pugh, L.C. (1981, Dctcber). The man-machire interface and plant operations. Paper presented at the 1981 ANs Nuclear Technology Exhibit, Beijing, China. 
Ramsey, J.R., \& Atwood, M.E. (1979, September). Human factors in computer systems: A zeview of the literature (Technical fioport SAT-79-11-DEN). McLean, VA: Science Applications, Inc.

Rigby, L.V., \& Cooper, J.I. (1961, October). Problems and procedures in maintainability (ASD Technical Note 61-126). Wright-Pattersan AFB, OH: Air Force Behavioral Sciences Loboratory. (NTIS AD-273-108)

Rigby, L.V., Cooper, J.l., \& 5pickard, W.A. (1961, October). Guide to integrated system design for maintainability (ASD Technical Report 61-424). Wright-Patterson AFB, OH: Air Force Behavioral Sciences Laboratory.

Siels, D.L., Wolf, C.P., \& Shelansk, V.B. (Eds.). (1981). The accident at Three Mile Island: The humen dimensions. Boulder, CO: Westview.

Smith, D.J., \& Babb, A.H. (1973). MainLainabilicy engineering. New York: John Wiley \& Sons.

Tew, J.L., Knuth, D., \& Boyd, R. (198], February). Radiological controls and worker and public health and safety. Albuquerque, NM: Sandia National L $\theta^{\mathrm{L}}$, ratory.

Trauth, C.A., Jr., Ellingson, A.C., Farr, D.E., \& Jercinovic, L.M. (1978, December). Application of quaiity assurance human factors and relitbility principles to the prevention of major environment, safety, and health incidents. Albuquerque, NM: Sandia National Laboratory.

U.S. Atomic Energy Commission. (1973, July). The safety of nuclear power reaciors (light-water-cooled) and related facilities (Technical Report WASH-1250), Washingtor, DC: Autror.

U.S. Navy. (1975). Interservice pro edures for instructional systems developinent (NAVDETRA 106, A). Alexandria, VA: Author.

Zahn, H.S. (1979). Developing maintainability for fusion power systems (Fina! Report). Vlası ington, DC: Department of Energy. (NTIS COO-4194-8) 



\section{ADVANCED CONTROL ROOM}

Boone \& Banks (1980) (EGG-SSDS-5288)

Clark, Banks, Blackman, \& Gertmen (1982) 


\section{ANMUCIATORS/ALARMS}

American Nuclear Society (1979) (ANSI/ANS N2.3-1979)

Begchi \& Gottilla (1981)

Banks \& Boone (1981) (NUREG/CR-2147)

Danchak (1982) (NIJREG/CR-2776)

Instrument Society of America (1979) (ISA S1B.1)

Meijer \& Safryn (1981) (C-E Document No. IPDR-81-004)

Merritt (1980)

Rankin, Duvernoy, Morgenstern, Ames, \& Eckentode (1983) (NUREG/CR-3217)

Roscoe (1984) (NUREG/CR-3684)

Staff (1969)

Wait \& Marning (1980) (NUREG/CR-1468) 


\section{ANTHROPOMETRY}

Cochran \& Riley (1982)

Cochran \& Riley (1993)

Das \& Grady (1985)

Deeb, Drury, \& Begbie (1983)

Easterby, Kroemer, \& Chaffin (Eds.) (1980)

Kohl (1983)

Letbetter (1982)

Parris \& McConville (1981) (EPRI NP-1918-SR)

Replogle (1983)

Scheller (1983)

Webb Assaciates 'Eds.) (1978) 


\section{CRT, VDTs, SPDS}

Banks (1980) (5D-D-80-002)

Banks (1981) (SD-B-81-002)

Banks \& Baone (1981)

Banks \& Clerk (1981) (SD-B-81-001)

Banks, Gertman, \& Petersen (1982) (NUREG/CR-2496)

Banks, Meyer, \& Jlark (1980)

Blackman, Gertman, Gilmore, \& Lord (1983) (NUREG/CR-3556)

Bray, Petersen, Clark, \& Gertman (1981) (EGG-M-09581)

Brooke \& Duncan (1983)

Cakir, Hart, \& Stewart (1980)

Danchek (1977)

Danchak (1981) (NUREG/CR-1994)

Electric Power Research Institute (1982) (EPRI-NSAC-40)

Electric Power Research Institute (1982) (EPRI-NP-2239)

Frey \& Kismer (1982) (NUREG/CR-2586)

Gertman, Blackman, Banks, \& Petersen (1982) (NUREG/CR-2942)

Gertman, Blackman, \& Banks (1982) (EGG-SSDS-5878)

Grandjean \& Vigliani (Eds.) (1980)

Helander (1982)

Helander, Billingsley, \& Schurick (1984)

Kershner, Gebhard, Silverman, \& Pannel (1982)

Lerser \& Robb

Lutman, Petrick, \& Hallam (1982) (EPRI-NSAC-45)

Luxenberg \& Kuehn (1968) 
CRTE, VDTs, SPDS

(continued)

Matula (1981)

Nuclear Regulatory Commission (1981) (NUREG-0835)

Olsen (E.d.) (1981)

Ramsey, Atwood, \& Kirshbaum (Eds.) (1978)

Salvendy (Ed.) (1984)

Straker (1981) (EPRI-N5AC-39)

Tuгnег \& Karssęk, Jr. (1983) 


\section{CDMPUTER-BASED SYSTEMS}

American Nuclear Society (1979) (ANSI/AN5 10.5-1979)

Brown, Burkleo, Mangelsdorf, Olsen, \& Williams, Jr. (1981)

Cakir, Hart, \& Stewart (1980)

Card, Moran, \& Newell (1993)

Dowling, Bybee, Shukla, Howland, Blomsnes, \& Netland (1978) (EPRI NP-640)

Engel \& Granda (1975) (TR 00.2720)

Frey \& Kismer (1982) (NUREG/CR 2586)

Institutt for Energiteiknikk (1981)

Martin (1973)

Price, Maisano, \& Van Cott (1981) (NUREg/CR-2623)

Pulliam, Price, Bongarra, Sawyer, \& Kisner (1983) (NUREG/CR-3331)

Ramsey \& Atwood (1979)

Ramsey, Atwood, \& Kirshbaum (Eds.) (1978)

Rosșiter \& Skolnick (1980)

Salvendy (1994)

Tillitt, Petersen, \& Smith (1982) (NUREG/CR-2711) 


\section{CONTROL ROOM DESTGN CRTIERLA \& REVIEW5}

American National Standards Institute (1980) (ANSI/IEEE Std 567)

American Nuclear Society (1983) (ANSI 58.6-1983)

BWR Owners Group (1980)

Enlarged Nordic Cooperative Program on Nuclear Safety (1981, June)

Finlayson (1977)

Friar, Fowler, \& Brown (1981)

Frogner \& Rá (1978)

Gonzalez \& Smith (1984)

Hartley, Levy, \& Fecht (1984) (NUREG/CR-3696)

Human engineering guide to control room evaluation, Volumes I \& II

Illuminating Engineering Society (1973) (Al1.]-1973)

Institute of Electrical and Electronics Engineers (1980) (ANSi/IEEE Std 567)

Institute of Electrical and Electronics Engineers (197i) (ANSI/IEEE Std 566)

Institute of Electrical and Electranics Engineers (1980)

Institute of Nuclear Power Operations (1982)

Luma, Guidetti, \& Rowland (1981)

Maddox (1983)

Maddox \& Brickey (1983)

Mallory, Fleger, Johnson, Avery, Walker, Baker, \& Malone (1980) (NUREG/CR-1580)

Nuclear Regulatory Commission (1981) (NUREG 0659)

Nuclear Regulatory Commission (1981) (NUREG 0700)

Nualear Utility Task Action Committee (1983) (INPO 83-026)

Nuclear Ltility Task Action Committee (1983) (INPO 83-036) 


\section{CONTROL ROOM DESIGN CRITERIA \& REVEWS}

(continued)

Nuclear Utility Task Action Committee (1983) (INPO 83-042)

Nucleas Utility Task Action Committee (1983) (INPO 83-046)

Pen, Miller, \& Feeher (1981) (EPRI-NP-1982)

Pine, Schulz, Edman, Hanson, Evans, Gonzales, Smith, \& Seminara (1982) (ERRI-NP-2411)

Pulliam, Price, Bongarra, Sawyer, \& Kisner (1983) (NUREG/CR-3331)

Sawyer, Pain, Van Cott, \& Banks (1982) (NUREG/CR-2828, EGG-2211)

Schroeder \& Fowler

Seidenstein, Williams, Goddard, \& Chesney (1981) (EPRI-EL-1960, Volumes 1-6)

Seminara (1982) (EPRI NP.2360)

Seminara, Eckert, Seidenstein, Gonzales, Stempson, \& Parsons (1979) (EPRI NP-1118-SY)

Seminara, Gonzalez, \& Parsons (1976) (EPRI NP-309)

Seminara \& Parsons (1979) (EPRI NP-1118)

Seminara, Seidenstein, Eckert, \& Smith (1979) (EPRI NP-1118)

Stewart (1981) (EGG-SSDS-5644)

Voss (1983)

Voss, Talley, \& Baker (1983)

Weiss (1983) 


\section{DISPLAYS \& CONTROLS}

Banks \& Boone (1981) (NUREG/CR-2147)

Cochran \& Riley (1982)

Cochran \& Riley (1983)

Deph, Drury, \& Begbie (1983)

Engel \& Granda (1975) (TR 00.2720)

Frey \& Kismer (1982) (NUREG/CR-2586)

Gertman, Blackman, Banks, \& Petersen (1982) (NUREG/CR-2942)

Hsu (1981)

Institute of Electrical and Electronics Engineers (1980) (IEEE 5td 603n-1980)

Luxenberg \& Kuehn : . 968)

Nelson (1984) (NUREG/CR-3631)

Replogle (1983)

Scheller (1983)

Weiss '1983) 


\section{EMERGENCY PLANNING \& RESPONSE}

American Nuclear Society (1983) (ANSI 58.6-2983)

Barks, Kozinsky, \& Eckel (NUREG/CR-2599)

Knuth \& Boyd (1981) (DOE/U5-0013)

Nuclear Regulatory Commission (1973) (NUREG 75/014)

Nuclear Regulatory Commission (1980) (NUREG-0654)

Nuclear Regulatory Commission (1981) (NUREG-0696)

Ramas, et al. (1981) (NUREG-0814) 


\section{HFE (GENTRAL)}

Acoustical Society of America (1971)

American National Stınderds instit ite (1971) (ANSI 91.2-1962)

Barter, Siegel, \& Federman (198?) (NUREG/CR-2668)

Benneti. (1977)

Burgy, Doyle, Barsam, \& Liddle (1980)

BWR Owners Group (1980)

Card, Maran, \& Newell (1983)

Department of the Air Force (1960) (AF SC DH 1-3)

Department of Defense (1975) (MIL-HLBK-759)

Department of $\Gamma$ fense (1979) (MIL-H-46855B)

Department of De ïense (1981) (MIL-STD-1472C)

DeSteese, Pelto, Rankin, Rideout, \& Shikiar (1992) (GRI-81/0106.1)

DeSteese, Pe'to, Rankin, Rideout, \& Shikiar (1982) (GRI-81/0106.2)

Enander (1983)

Failure Analysis Associates (1979) (EPRI AF-1041)

Gertner, Israeli, \& Cassuta ' 1984)

Grandjean (1980)

Haas (1982)

Helander (Ed.) (1981)

Hopkins \& Snyder (1982)

Hopkins, Snyder, Príce, Hornick, Mackie, Smillie, \& Sugarman (1982) (NUREGiCR-2833)

Illuminating Engineering Society (1973) (Al1.!-1973)

Kohl (1983)

Kubokswa, Woodsan, \& Selby (1949) (NASA Report No. CR114272) 
Lutman, Petrick, \& Hallam (1982) (EPRI-NSAC-45)

McCormick \&e Sanders (1982)

Meese, Kok, Lewis, \& Wyon (1984)

Meijer \& Gill (1980)

Meister (1984)

Meister \& Rabideau (I965)

Moray (Es.) (1979)

Morgan, Cook, III, Chapanis, \& Lund (1963)

Morse \& Swift (1982)

Olson, Schreiber, \& Melber (1984) (NUREG/CR-3785)

Perker, Jr., \& West (Eds.) (1973)

Pauls (1983)

Price, Maisano, \& Van Cott (1981) (NUREG/CR-2623)

Riso National Laboratory (Eds) (1982)

Radgers \& Eggleton (Eds) (1983)

Sabri (1980)

Seeman, Colley, \& Stratton (1983)

Shackel (Ed.) (1978)

Sheeh" (1983)

Sheridan \& Johannsen (Eds.) (1976)

Swair (1980)

Topmiller, Burgy, Roth, Doyle, \& Espey, Jr. (1.98I) (EPRI NP-2035)

U.S.A. Standiurds Institute (1960) (USAS 53.2-1960) 


\section{HFE (GENERA)}

\section{(continusod)}

Van Cott \& Kinkade (Ed3) (1972)

Voss (1983)

Woodson (1981)

Wright (197') 


\section{HFE REQUREMENTS \& STUDIES}

Banks \& Boone (1981)

Edsberg (1981)

El-Bassioni, Hedrick, Starostecki, \& Penland

Hopkins, Snyder, Price, Hornick, Mackie, Sinillie, \& Sugarmen.(1982) (NUREG/CR-2833)

Tiesenhausen (1982) (NASA TM-82510) 


\section{JOB PERFORMANCE ADDS}

American National Standards Insitute (1971) (ANS1 91.2-1962)

Anderson (1981) (ORNL/FTR-1032)

ileare, Dorris, Bovell, Crowe, \& Kozjnsky (1983) (NUREG/CR-3309)

Foley, Jr. (1973) (AFHRL-TR-72-73)

Hoitman, Bateman, \& Biers (1982) (NUREG/CR-2712)

Joyce, Chenzoff, Mulligan, \& Mallory (1972) (AFHRL-TR-73-43)

Lineberry \& Bullack (1980)

Moraal \& Kraiss (Eds.) (1981)

Price, Post, \& Kolsrud (1.971) 


\section{MAINTENANCE \& REบABILTTY}

Amei ican National Standards Institute (1972) (ANSI 18.7-1976);

Baker (1980, Februery)

Barter, Siegel, \& Federman (1962) (NUREG/CR-2668)

Beare, Dorris, Bovell, Crowe, \& Kozinsky (1983) (NUREG/CR-3309)

Bell \& Swain (1983) (NUREG/CR-2254)

Brune \& Weinstein (1980) (NUREG/CR-1369)

Clarke, Gerin, \& Preston-Anderson (1981)

Comer, Koz insky, Eckel, \& Miller (19R3) (NUREG/CR-2744)

Cunningham \& Cox (1972)

Doyle, Lothar, \& Brewe: (1993)

Embrey (1983) (NUREG/CR-2986)

Embrey, Humphreys, Rose, Kirwan \& Rea (1984) (NUREG/CR-3516)

Finnegan \{1980) (EPRI AP-1470)

Griffon (1979)

Haas \& Bott (1980, April)

Hall (1982) (NUREG/CR-3010)

Koukol, Lapin, Leverton, \& Pickering (1980) (EPRI NSAC-4)

McKeithan \& Kfoury (1983)

Morse \& Swift (1982, April)

Onodera, Miki, Nukada, \& Nakamura (1982)

Post, Price, \& Diffley (1976)

Riso National Leboratory (Eds.) (1992)

Samanta, Swaboda, \& Hali (1981) (N.UREG/CR-1879) 


\section{MANTENANCE * REIABHSTY}

(continued)

Seminara (1982) (EPRI NP-2360)

Seminara, Parsons, Schmidtt, Ganzalez, \& Dove (1980) (NP-1567-5Y)

Sheridan (1980, February)

Shives \& Willard (Eds) (1981, April)

Siegel, Bartter, \& Kopstein (1982) (NUREG/CR-2670)

Siegel, Bartter, Wolf, Knee, \& Haas (1983) (NUREG/CR-2669)

Smidt (1980, Navember)

Speaker, Thompson, \& Luckas, J5. (1982) (NUREG/CR-?417)

Stewart (1981) (EEG-5SDC-5580)

Stewart (1982)

Stilwell, Seaver, \& Schwartz (1982) (NUREG/CR-2255)

Swain \& Guttman (1980) (NUREG/CR-1276)

Topmiller, Eckel, \& Kozinsky (1982) (NUREG/CR-2744)

Toto \& Lindgren (1981) (DOE/US-008)

Vesely, Davis, \& Saltor (1983) (NUREG/CR-3541) 


\section{ORGANIZATIONAL COMMUNCATIONS}

Baumen, Davidson, \& Van Cott (1984)

Bauman, Pain, Vaл Cott, \& Davidson (1983) (EPRI NP-3i41)

Goldhaber, Rogers, Lesnick, \& Porter (1979)

Olson, McLaughlin, Osborne, \& Jacksan (1984)

Roberts \& O'Reilly, III (1974)

Selwsy, Jr. (1984, April)

Seminara \& Pack (1982) 


\section{PERSONNE SEECTION\& STAFTNG}

American Nuclear Society (1970) (ANSI/ANS 3.1-1978)

Baumen, Pain, Van Cott, \& Davidson (1983)

Corcoran, Church, Cross, \& Porter (1981, Aprii)

Fullerton, Peelle, \& Reed (1982) (NUREG/CR-345B)

Kisner \& Frey (1981) (NUREG/CR-2587)

Lindell (1983)

Helber \& Schreiber (1983) (NUREG/CR-2952)

Shea, Jr. (1981, October) 


\section{PRCEEDURES}

American National Standards Institute (1972) (ANSI 18.7-1976)

Brune \& Weinstein (1981) (NUREG/CR-2005)

Canadian Standards Association (1979) (CSA N286.5-1979)

Department of Defense (1977) (MIL-HDBK-63038-1(TM))

The Emergency Operating Procedures Implementation Assistance (EOPIA) Review Group (1983) (INPO 83-004)

The Emergency Operating Procedures Implementation Assistance (EOPIA) Review Group (1982) (INPO 82-017)

The Emergency Operating Procedures Implementation Assistance (EOPIA) Review Group (1982) (INPO 82-013)

The Emergency Operating Procedures Implementation Assistance (EOPIA) Review Graup (1983) (INPO 83-006)

The Emergency Operating Procedures Implementation Assistance (EOPIA) Review Group (1983) (INPO 82-016)

Fuchs, Engelschall, \& Imlay (1981) (NUREG/CR-1999)

Fuchs, Engelschall, \& Imlay (1981) (NUREG/CR-1875)

Green (1984) (NUREG/CR-2940)

Kammann (1979)

Lindell (1983)

Morgenstern, Clausen, Foley, Levy, Myers, Rankin, \& Shikiar (1981) (NUREG/CR-1977)

Myers \& Bell (1984) (NUREG/CR-3632)

Naval Áir Systems Command (1980) (NAVAIR 00-25-700)

Nelson, Clark, \& Banks (1981) (NUREG/CR-1995)

Nuclear Regulatory Commission (1982) (NUREG-0899)

Olsan, Schreiber, \& Melber (1984) (NUREG/CR-3795)

Post, Price, \& Diffley (1976)

Potash (1980) (EGG-5SDC-5223) 


\section{PROCEDURES}

(continved)

Pulliam, Price, Eongarra, Sawyer, \& Kisner (1983) (NUREG/CR-333I)

Siegel, Federman, \& Burkett (1974) (AFHRL-TR-74-26)

Siegel, Lamuert, \& Burkett (1974) (AFHRL-TR-74-47)

Speaker, Thompsun, \& Luckas, 3r. (1982) (NUREG/CR-2417)

Taylor \& Voss (1981)

Toto \& Lindgren (1981) (DOE/U5-008)

von Herrmann (1983) (NUREG/CR-3177) (3 volumes)

Wright (1981, September) 


\section{SIMLSATORS}

Beare, Crowe, Kozinkky, Barks \& Hags (1982) (NUREG/CR-2534)

Beare, Dorris, \& Kozinsky (1982)

Bolton, Faigenblum, Hope, \& Rankin (1984) (NUREG/CR-3726)

Bott, Kozinsky, Crowe, \& Haes (1981) (NUREG/CR-1908)

Electric Power Research Institute (1982) (EPRI-NSAC-40)

Hollnagel, Pedersen, \& Rasmussen (1981) (RIS0-M-2285)

Moraal \& Kraiss (Eds) (1981)

Oak Ridge National Laboratory (1981) (NUREG/CR-2353)

Rankin, Bolton, Shikiar, \& Saari (1984) (NUREG/CR-3785) 


\section{THREE MILE ISLAND STUDES}

Fischetti, Adam, Elsenhut, \& Horgan (1984, April)

Nuclear Regulatory Commission (1979) (NUREG-0585)

Nuclear Regulatory Commission (1980) (NUREG-0737)

Nuclear Regulatory Commission (1980) (NUREG-0660)

Rogovin, Frampton, Jr., Cornell, DeYoung, Budnitz, \& Norry (1980) (NUREG/CR-1250, Volume 1)

Rogovin \& Frampton, Jr. (1980) (NUREG/CR-1250, Volume 2) 


\section{TRAMNG}

Analysis and Technology (1983) (DOE EP-0095)

Bartter, Siegel, \& Federman (1982) (NUREG/CR-2668)

Blackman, Gertman, \& Petersen (1963) (EEG-REP-6274)

Bockhold, Jr., \& Roth (1978) (EPRI-NP-7R3)

Bolton, Faigenblurri, Hope \& Rankin (1984) (NUREG/CR-3726)

Burgy, Newell, \& Van Cott (1982, October)

Department of Energy (1993) (DOE/EP-3095)

Department of Energy (1984) (DOE/EV/10782-T1)

Dutton \& Brown (1981, April)

Enlarged Nordic Cooperative Program on Nuclear Safety (1981, Jurre)

Gertman, Blackman, Gilmore, \& French (1983) (EEG-REP-6273)

Green (1984) (NUREG/CR-2540)

Haas, Selby, Hanley, \& Mercer (1983) (NUREG/CR-3414, ORNL-TM-8848)

Hollnagel, Pedersen, \& Rasmussen (1981) (RISO-M-2285)

Hattman \& Eateman (1982)

Hottman, Bateman, \& Biers (1982) (NUREG/CR-2712)

Institute of Nuclear Power Operatione (1982) (INPO B2-011)

Institute of Nuclear Power Operations (1984)

Oak Ridge National Laboratory (1981) (NUREG/CR-2353)

Olson, Schreiber, \& Melber (1984) (NUREG/CR-3785)

Rankin, Bolton, Shikiar, \& Saari (1984) (NUREG/CR-3725)

Sawyer, Pain, Van Cott, \& Banks (1982) (NUREG/CR-2828, EGG-2211) 


\section{VALDATION\& VERIFTCATION}

Department of Energy (1984) (DOE/EV/10782-T1)

Electric Power Research Institule (1982) (EPRI-NSAC-40)

Hollnagel (198I) (RISO-M-2313)

Hottman, Butemen, \& Biers (1982) (NUREG/CR-2712)

Prize, Post, \& Kolsrud (1271)

Straker (1981) (EPRI-NSAC:-39) 


\section{WOMEN}

Letbetter (1982)

Mackay \& Bishop (1984)

Ward (1984) 


\section{OTHER}

\section{Advisory Committee cn Reactor 5afeguards (1980) (NUREG-073y)}

Banks \& 5prague (1982)

Code of federal regulationo (1984)

Felker (Ed.) (1980) (A/R-75002-4/80-TR)

Nuclear Regulatory Commission (1980) 